Brigham Young University Law School

BYU Law Digital Commons

Faculty Scholarship

4-30-1996

Corporate Governance and Managerial Incompetence: Lessons from Kmart

D. Gordon Smith

Follow this and additional works at: https://digitalcommons.law.byu.edu/faculty_scholarship

Part of the Business Law, Public Responsibility, and Ethics Commons, and the Business Organizations Law Commons

Recommended Citation

D. Gordon Smith, Corporate Governance and Managerial Incompetence: Lessons from Kmart, 74 N.C. L. REV., 1037 (1996).

This Article is brought to you for free and open access by BYU Law Digital Commons. It has been accepted for inclusion in Faculty Scholarship by an authorized administrator of BYU Law Digital Commons. For more information, please contact hunterlawlibrary@byu.edu. 


\title{
CORPORATE GOVERNANCE AND MANAGERIAL INCOMPETENCE: LESSONS FROM KMART
}

\author{
D. GORDON SMITH*
}

Modern corporate governance scholars often extol an activist role by institutional investors in directing corporate activity. Widely viewed as a solution to the "collective action" problems that inhibit such activism by individual investors, institutional investors are praised for adding value to corporations through their participation in the decisionmaking process. The ouster of Joseph Antonini as Chief Executive Officer of Kmart Corporation in 1995 might be taken as a vindication of this view, because substantial evidence indicates that institutional investors played a crucial role in influencing Kmart's board of directors to remove him. In this Article, Professor Gordon Smith challenges this potential reading of the events at Kmart. Professor Smith poses the fundamental question of whether institutional investor activism designed to address perceived incompetence among corporate managers consistently adds value to corporations in which such activism is present. Professor Smith analyzes the effect of internal and external forces on managers, particularly on Antonini. and Kmart's directors, and derives two fundamental lessons: (1) External constraints are ineffective in solving managerial incompetence; and (2) Investor activism will often be counterproductive because it destroys the value of centralized decisionmaking.

INTRODUCTION $\ldots \ldots \ldots \ldots \ldots \ldots \ldots \ldots \ldots \ldots \ldots \ldots \ldots \ldots \ldots$

I. JOE ANTONINI'S KMART . . . . . . . . . . . . . . . 1046

II. KMART'S CORPORATE GOVERNANCE PROBLEM AND HOW THE CORPORATE GOVERNANCE SYSTEM DEALT WITH IT . 1057

A. Kmart's Corporate Governance Problem . . . . . . . 1059

* Assistant Professor of Law, Northwestern School of Law of Lewis \& Clark College. Thanks to Brian Blum, Jack Bogdanski, Ed Brunet, Jennifer Johnson, Laura Lin, and Doug Newell for helpful comments and to Andrew Ognall and Lee Street for excellent research assistance. Special thanks to Randall Thomas, not only for useful comments on this Article, but for consistently good advice and encouragement generally. This Article is dedicated to Sue Smith. 
B. External Constraints on Managerial Behavior ....... 1062

1. Capital Markets .................... 1062

2. Market for Corporate Control . . . . . . . . . 1072

3. Product Markets . . . . . . . . . . . . . . . . . 1075

4. Managerial Labor Markets ... . . . . . . . . . . 1079

C. Internal Constraints on Managerial Behavior . . . . . 1081

1. Board of Directors . . . . . . . . . . . . . . 1082

a. Separation of CEO and Chairman Positions .. 1083

b. Outside Directors . . . . . . . . . . . . . . . 1084

c. Executive Compensation ............ 1088

d. Dividend Policy . . . . . . . . . . . . . . . . 1092

e. Debt Policy . . . . . . . . . . . . . . . . . . . 1096

2. Shareholders ... . . . . . . . . . . . . . . . . 1099

a. Shareholder Voting $\ldots \ldots \ldots \ldots \ldots \ldots 1100$

b. Shareholder Suits ... . . . . . . . . . . 1102

c. Institutional Investor Activism . . . . . . . . . 1104

III. Two FundAMENTAL LESSONS From KMART $\ldots \ldots \ldots \ldots 1110$

A. Lesson \#I: External Constraints Will Not

Efficiently Solve Managerial Incompetence . . . . . . . . 1113

B. Lesson \#2: Institutional Investors Will Not

Efficiently Solve Managerial Incompetence . . . . . . . 1115

1. Categories of Shareholder Participation ....... 1117

2. The Value of Centralized Decisionmaking .... . . . 1119

3. A Theory of Representation for Corporate

Shareholders ....................... 1122

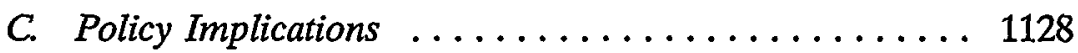

1. Encouraging Board Composition Participation ... 1129

2. Discouraging Policy Participation ......... 1134

IV. Conclusion ....................... 1137

\section{INTRODUCTION}

Three days after Joseph Antonini was forced to resign as Chief Executive Officer of Kmart Corporation, The Wall Street Journal ran a front-page story with the headline: "How Wal-Mart Outdid a OnceTouted Kmart in Discount-Store Race." 1 The story compared Antonini unfavorably with Sam Walton, founder of Kmart-nemesis Wal-Mart Stores Inc., and declared Wal-Mart the victor in the

1. Christina Duff \& Bob Ortega, How Wal-Mart Outdid A Once-Touted Kmart In Discount-Store Race, WALL ST. J., Mar. 24, 1995, at A1. 
discount store competition. Although competition from Wal-Mart was instrumental in provoking Antonini's ouster, the direct impetus for his ouster was Kmart's shareholders. In June 1994, nine months before Antonini resigned, Kmart's shareholders defeated a proposal endorsed by Kmart's board of directors to raise money for the renovation of Kmart's discount stores through the sale of "targeted stock"-Kmart common stock with returns tied to the performance of Kmart's specialty retail subsidiaries, such as OfficeMax office supply stores and Borders and Waldenbooks book stores. The most vocal opponents of the targeted stock proposal claimed that Antonini was distracted by specialty retailing and that, instead of selling targeted stock, Kmart should sell its specialty retailing subsidiaries outright and focus on Kmart's core business, discount retailing. The shareholder vote was quickly recognized by observers as "one of the most astonishing investor rebellions in corporate history.".

In response to the shareholder vote, Antonini agreed to adopt the strategy advocated by dissident shareholders and announced plans to sell the specialty retail subsidiaries. ${ }^{3}$ Although the shareholder vote appeared to give directors "a clear mandate to shake up top management," several candidates the board considered to replace Antonini reportedly were nervous about the prospect of working under Antonini without some assurance about when they would assume leadership of the company. ${ }^{5}$ Six months after the shareholder vote, having failed to find a successor for Antonini and still facing pressure from shareholders, Kmart's board of directors removed Antonini as Chairman of the Board and named Donald Perkins-a respected former chairman of Jewel Companies, Inc.-as his temporary successor. ${ }^{6}$ Commenting on Antonini's removal as Chairman,

2. David Woodruff \& Judith H. Dobrzynski, Revolt? What Revolt?: Kmart Sticks to Its Turnaround Plan, Bus. WK., June 20, 1994, at 42; see also Bankers Undaunted By 'No' On Kmart Targeted Stock, GoING PUB.: THE IPO REP., June 13, 1994, at 1, 5 [hereinafter Bankers Undaunted] (quoting a Kmart investment banker as saying, "This was one of the great surprises of all time"); George White, Kmart Gets Red Light on Specialty Stock Plan Retailing: Shareholders Rebuke Management's Proposal to Raise $\$ 600$ Million by Selling Shares in Other Units, L.A. TIMES, June 4, 1994, at D1, D2 (quoting Kurt Barnard, a New York-based retail economist: "This is an extraordinary slap to the face of Kmart's management .... It's a new chapter in shareholder relations").

3. See infra notes $99-105$ and accompanying text.

4. Joann S. Lublin \& Christina Duff, How Do You Fire a CEO? Very, Very Slowly, WALL ST. J., Jan. 20, 1995, at B1, B2.

5. Christina Duff \& Joann S. Lublin, Kmart Board Ousts Antonini as Chairman, WALl ST. J., Jan. 18, 1995, at A3; Ellen Neuborne, Kmart chief Antonini calls it quits, USA TODAY, Mar. 22, 1995, at 1B.

6. Duff \& Lublin, supra note 5 , at A3. 
James Severance of the State of Wisconsin Investment Board (SWIB), a public pension fund and Antonini's most visible antagonist, said, "The board was too passive. If this represents the board asserting itself, then that's good news."7

Antonini's removal as Chairman, however, appears to have been less a signal of the board's resolve than an attempt to ward off shareholder pressure. Perkins later admitted that he had hoped his appointment as Chairman would buy Antonini some time as CEO. ${ }^{8}$ And in February the board of directors appeared to have given up the search to replace Antonini as CEO. ${ }^{9}$ But Kmart's shareholders were restless. Perkins commented that, after being named Chairman, he had "a number of discussions" with shareholders about Antonini's continued role with the company. ${ }^{10}$ SWIB's Severance promised, "We are going to continue to keep Joe's and the board's feet to the fire."11 On March 20, major Kmart shareholders met with Perkins. Although Perkins expressed confidence in Antonini, the shareholders' message was simple: "Joe has to go."12 The next day, Kmart's board of directors unanimously agreed to ask Antonini to resign. ${ }^{13}$

One view of the events at Kmart holds that this is corporate governance at its best: Institutional investors dissatisfied with the performance of a company in which they had invested took aggressive action to change the company's strategic course and replaced the CEO. Much has been written about the potential contribution of institutional investors to the governance of American corporations, ${ }^{14}$

7. Id. Trading in Kmart common stock on the day following Antonini's ouster was heavy, and the price rose $\$ 0.25$ (or $1.9 \%$ ) to $\$ 13.50$ per share in New York Stock Exchange composite trading. Id.

8. Daniel Howes, How Antonini Lost Kmart Post, GANNETT News SERviCE, Mar. 21, 1995, available in WESTLAW, Allnews Database, 1995 WL 2890330, at *2.

9. Christina Duff, Kmart Calls Off Search to Find Antonini Heir, Wall ST. J., Feb. 23, 1995, at A3. After this report appeared in The Wall Street Journal, Kmart denied even searching for a replacement for Antonini. Glenn Collins, Kmart Denies Report on Search, N.Y. TIMES, Feb. 24, 1995, at D3.

10. Howes, supra note 8 , at $* 2$.

11. Judith H. Dobrzynski \& Stephanie Strom, A Likely Next Company For a Board Room Coup: Atop Kmart, Patience is Wearing Thin, N.Y. TIMES, Mar. 15, 1995, at D1, D6.

12. Christina Duff et al., Kmart's Embattled CEO Resigns Post Under Pressure From Key Shareholders, WALL ST. J., Mar. 22, 1995, at A3 (quoting Perkins).

13. Id. Despite all of the signs, Antonini appeared not to see the end coming; just 18 days prior to his resignation, he purchased 20,000 shares of Kmart stock on the open market. Dave Kansas, Antonini Bought Shares Before Ouster at Kmart, WALL ST. J., Apr. 5,1995 , at $\mathrm{C1}$ (noting also that because of the rise in Kmart's stock price upon his resignation, Antonini quickly gained $\$ 20,000$ on the investment).

14. See sources cited infra part II.C.2.c. 
and the events at Kmart demonstrate both their extensive power and their willingness to exercise it.

Regardless of whether Antonini's ouster was the "right" thing for Kmart, the more important question for corporate governance scholars is whether this type of participation by institutional investors is desirable. Placing the debate in the context of Kmart, however, focuses the inquiry: When institutional investors are dissatisfied with the performance of a company in which they have invested, how much power should the corporate governance system grant those investors to pursue their own remedy, rather than relying on market checks or the board of directors?

The answer to that question depends first on the nature of investors' concerns and second on the relative effectiveness of corporate governance mechanisms in resolving such concerns. With respect to the former, Kmart's investors were concerned about perceived deficiencies in Antonini's performance. Deficiencies in managerial performance may usefully be divided into two types: managerial abuse and managerial incompetence. Managerial abuse describes the behavior of the manager who shirks responsibility or diverts corporate assets for personal use. Managerial abuse arises because of the inability of the board of directors to provide managers with proper incentives for efficient behavior. ${ }^{15}$ This is the problem of "moral hazard."16 Managerial incompetence describes the behavior of the manager who earnestly strives to meet shareholder expectations but simply is not up to the task. ${ }^{17}$ Managerial incompetence arises because of the inability of the board of directors to

15. See Ian Ayres \& Peter Cramton, Relational Investing and Agency Theory, 15 CARDozo L. Rev. 1033, 1044 (1994).

16. Id. Moral hazard arises because the actions of an agent are unobservable by the principal. When information is improved, principals are better able to monitor agents and agents' incentives to perform improve. See Bengt Holmström, Moral Hazard and Observability, 10 BELI J. ECON. 74 (1979); Steven Shavell, Risk Sharing and Incentives in the Principal and Agent Relationship, 10 BELL J. ECON. 55 (1979).

17. This view of incompetence uses shareholder expectations as the standard by which managerial performance is measured, but should not imply that every time shareholders are dissatisfied with a company's performance, the managers are incompetent. Instead, this view of incompetence acknowledges that managers should serve shareholders' interests and assumes that managerial performance is reflected, even if imperfectly, in the long-term performance of a company and ultimately in the company's stock price. See infra part II.B.1. 
judge properly the competence of the managers they hire. ${ }^{18}$ This is the problem of "adverse selection."19

The moral hazard/adverse selection dichotomy is useful because the cures for each deficiency are distinct. As noted by Ian Ayres and Peter Cramton, moral hazard can be mitigated only by providing managers with incentives not to shirk or divert corporate assets. ${ }^{20}$ Adverse selection, on the other hand, cannot be corrected by improving the incentive scheme because no incentive can cause a manager to perform beyond his or her ability. ${ }^{21}$ As Joseph Grundfest is reported as saying: "there is no incentive large enough to make [me] hit a 95 mile per hour fast ball."22 Adverse selection is corrected only by replacing the incompetent manager with a competent manager. During the events at Kmart there have been no accusations of managerial abuse against Antonini. For reasons explained more fully below, this Article will assume that investors

18. Ayres \& Cramton, supra note 15 , at 1044.

19. Id. Adverse selection arises because some attribute of an agent is unobservable to the principal. See George A. Akerlof, The Market for "Lemons": Quality Uncertainty and the Market Mechanism, 84 Q.J. ECON. 488 (1970).

20. Ayres \& Cramton, supra note 15 , at 1052 :

If a manager's incentive scheme ... fails to eliminate the possibility of moral hazard (to shirk or otherwise act unfaithfully), then economic theory suggests that any "rational manager" will succumb. Replacing a manager who succumbs to moral hazard should not by itself change the equilibrium-any new manager facing the same incentive scheme will behave in the same manner.

The assumption that any "rational" manager will succumb to temptation depends on a notion of rationality that assumes "that agents in a wide variety of situations value the same sorts of things: for example, wealth, income, power, or the perquisites of office." John Ferejohn, Rationality and Interpretation: Parliamentary Elections in Early Stuart England, in THE ECONOMIC APPROACH TO POLITICS: A CRITICAL REASSESSMENT OF THE THEORY OF RATIONAL ACTION 279, 282 (Kristen R. Monroe ed., 1991). Ferejohn labels this view of rationality "thick rationality." Id. "Thin rationality," on the other hand, assumes only that agents "efficiently employ the means available to pursue their ends" without specifying those ends. Id. Under a "thinner" interpretation of rationality than adopted by Ayres and Cramton, for example, "rational" managers may resist the temptations of moral hazard simply because they are honest. On the role of honesty in business transactions, see generally FRANCIS FUKUYAMA, TRUST: THE SOCIAL VIRTUES AND THE CREATION OF PROSPERITY 36 (1995) ("Most people are simply habituated to a certain minimal degree of honesty. Gathering the necessary information and considering possible alternatives is itself a costly and time-consuming process, one that can be shortcircuited by custom and habit."). Nevertheless, Ayres and Cramton's assumption is useful in designing an incentive scheme in the same way that Holmes's "bad man" is useful in framing law. See Oliver W. Holmes, The Path of the Law, 10 HARV. L. REV. 457, 459 (1897).

21. Ayres \& Cramton, supra note 15 , at 1052.

22. Ronald J. Gilson, Executive Compensation and Corporate Governance; An Academic Perspective, in 24TH ANNUAL INSTITUTE ON SECURITIES REGULATION 647, 669 70 (PLI Corp. L. \& Practice Course Handbook Series No. B4-7017, 1992). 
were concerned about Antonini's competence and, therefore, the problem of adverse selection, not moral hazard.

After identifying the nature of Kmart investors' concerns as managerial incompetence, the analysis turns to an examination of the relative effectiveness of corporate governance mechanisms in resolving that concern. As noted above, the only corrective measure for managerial incompetence is removal of the incompetent manager. Whether directors, shareholders, acquirors, or the forces of product competition are involved, ${ }^{23}$ two types of error must be considered: "type I errors" occur when an incompetent manager is retained, and "type II errors" occur when a competent manager is removed. ${ }^{24}$ Both types of error impose significant costs on a corporation, ${ }^{25}$ and one goal of the corporate governance system should be to reduce the total error costs associated with decisions about managerial incompetence. $^{26}$

With respect to the relative effectiveness of institutional investors and other corporate governance mechanisms in correcting for managerial incompetence, surprisingly little has been written. Over the past two decades, corporate governance scholars-particularly financial economists-have made tremendous progress in understanding the corporate governance system by expanding the concept of

23. For a discussion of the effect of competition in product markets, see infra part II.B.3.

24. Cf. Ayres \& Cramton, supra note 15, at 1037 ("Thus, we might usefully distinguish between situations where good managers might mistakenly be fired ... and those where bad managers might mistakenly be retained. . . . An important goal of corporate governance is to efficiently reduce both of these types of error.").

25. The costs imposed by type I errors are obvious: A corporation managed by an incompetent manager will perform below its potential, imposing significant costs on both shareholders and society. The costs imposed by type II errors are less obvious but nonetheless potentially significant. Any management change will result in costs to the corporation as the corporation must search for a new manager and adapt to that new manager's style and policies. These costs may include increased moral hazard problems:

It is also likely that efforts to solve adverse selection problems by replacing managers would exacerbate managerial moral hazard. Often, upper-tier managers are privy to key information that is useful in controlling the moral hazard of underlings. One needs to think only of the way that students often exploit a new or substitute teacher in order to envision how replacing incumbent upper management on adverse selection grounds could lead to heightened moral hazard by lower-level employees.

Ayres \& Cramton, supra note 15, at 1055. Another cost of type II error is the effect on the company's stock. Naveen Khanna and Annette Poulsen recently found that market reaction to replacement of managers is significant and negative for both financially distressed and other firms. Naveen Khanna \& Annette B. Poulsen, Managers of Financially Distressed Firms: Villains or Scapegoats?, 50 J. FIN. 919, 929-33 (1995).

26. Ayres \& Cramton, supra note 15 , at 1037. 
"corporate governance" from a narrow emphasis on legal rules to a broader recognition of the role of external forces that influence corporate decisionmaking, including capital markets, the market for corporate control, product markets, and managerial labor markets. ${ }^{27}$ Unfortunately for purposes of solving managerial incompetence, external forces constrain managerial behavior primarily by providing incentives for good performance, not by replacing managers, thus allowing type I errors. Even when external forces replace managers, through takeovers or by driving a firm out of business, they may often replace competent managers, a type II error. Drawing from the vast literature regarding external constraints on managerial behavior, therefore, this Article derives the first fundamental lesson from Kmart: External constraints on managerial behavior are ineffective methods of dealing with managerial incompetence because they are prone to produce both type I and type II errors.

Given the inherently limited ability of external constraints to protect against managerial incompetence, improvements in dealing with managerial incompetence are most likely to come from improving the effectiveness of internal constraints, namely, the board of directors or the shareholders. Like external constraints, directors and shareholders may produce both type I and type II errors; however, unlike external constraints, changes in the process by which directors and shareholders make decisions are likely to reduce significantly the total errors. One purpose of this Article, therefore, is to propose areas in which reforming internal constraints is most likely to reduce the total error costs associated with decisions regarding managerial incompetence.

As evidenced by Kmart, shareholders can be very aggressive and effectively achieve their goals. If the goal of corporate governance reform were simply to make replacement of incompetent managers easier (i.e., to reduce type I errors), institutional investor activism would unquestionably be a useful supplement to the available mechanisms. But the goal is not simply to reduce type I errors; rather, it is to reduce total errors. The purpose of corporate governance reform, therefore, must be to improve the likelihood of reaching a correct decision.

27. For the narrow use of "corporate governance," see, for example, Daniel R. Fischel, The Corporate Governance Movement, 35 VAND. L. REv. 1259 (1982). For more recent and broader definitions, see AMERICAN LAW INSTITUTE, Chief Reporter's Foreword to PRINCIPLES OF CORPORATE GOVERNANCE: ANALYSIS AND RECOMMENDATIONS XXV (1994) [hereinafter ALI PRINCIPLES]; Gilson, supra note 22, at 653-56. 
- The likelihood of reaching a correct decision increases when the decisionmaker is independent, has access to information about the decision, and has proper incentives to reach a correct decision. ${ }^{28}$ There is little doubt that shareholders normally are more independent of management than directors, ${ }^{29}$ and that directors have a significant informational advantage over shareholders. ${ }^{30}$ Both may lack proper incentives to monitor-shareholders because of the collective action problem $^{31}$ and directors because they are beholden to managers or because their interests are not otherwise aligned with shareholders. ${ }^{32}$ Although developments over the past two decades have led to some optimism about the ability of institutional investors to overcome the collective action problem ${ }^{33}$ and the ability of directors to act independently, ${ }^{34}$ commentators uniformly envision a cooperative relationship in which both investors and directors play some role in corporate governance. The debate, therefore, revolves around the proper balance of responsibilities between these two groups.

Corporate law assigns directors the responsibility of managing or supervising the management of the corporation, ${ }^{35}$ a broad delegation of authority that includes both the formation of corporate strategy and the execution of that strategy. Shareholders have been assigned no direct role in managing the corporation. Instead, they monitor directors, primarily through annual director elections. In modern

28. Corporate law regulates the independence and information gathering of decisionmakers (usually the directors, although when controlling shareholders exist, they are subject to the same duties) through the imposition of the fiduciary duties of loyalty and care, respectively. The presence of these duties provides some incentive to reach correct decisions. Nevertheless, corporate law tends not to regulate the substance of decisions but rather the process by which they are made. The result is that fiduciary duties provide relatively weak incentives to make correct decisions.

29. See RoBERT A.G. MONKS \& NELl MINOW, CORPORATE GOVERNANCE 184, 193 (1995) (noting that "the CEO plays an important, even dominant role in the selection of director candidates").

30. See Jeffrey N. Gordon, Shareholder Initiative: A Social Choice and Game Theoretic Approach to Corporate Law, 60 U. CIN. L. REV. 347, $353-57$ (1991).

31. See MANCUR Olson, JR., THE Logic Of Collective ACTION: Public Goods AND THE THEORY OF GROUPS 2 (1965) (arguing that "rational, self-interested individuals will not act to achieve their common or group interests" because the benefits of action come to the group as a whole).

32. For a thorough discussion of reasons for passive boards of directors, see Charles M. Elson, The Duty of Care, Compensation, and Stock Ownership, 63 U. CiN. L. REv. 649 (1995).

33. See infra part II.C.2.c.

34. See infra part II.C.1.b.

35. See, e.g., DEL. CODE ANN., tit. 8, § 141 (1995); MODEL BUSINESS CORP. ACT $\S$ 8.01(b) (1984). 
public corporations, directors delegate much of their management authority to executive officers, but retain the a responsibility of hiring, monitoring, and firing executive officers. As will be discussed below, the exercise of this responsibility by the board of directors rather than shareholders is justified by the fact that the board functions as a centralized decisionmaker in a corporation and in that role improves the efficiency and quality of decisions that otherwise would be made by shareholders. If shareholders can override the discretion of the board of directors, the value of centralized decisionmaking-the primary value of the board of directors-is destroyed. Relying on both economic and political theory, this Article derives a second fundamental lesson from Kmart: When compared with action by the board of directors, institutional investor activism in evaluating the competence of executive officers may be counterproductive because it destroys the value of centralized decisionmaking by the board of directors.

Part I describes events relating to corporate governance at Kmart during Antonini's tenure. Part II examines the effectiveness of various corporate governance mechanisms in revealing and resolving Kmart's corporate governance problem of managerial incompetence. Part III concludes by identifying the two fundamental lessons from Kmart described above and examining certain policy implications of those lessons.

\section{JOE ANTONINI'S KMART}

The first Kmart discount store opened in $1962 .{ }^{36}$ Originally a creation of S.S. Kresge Co., Kmart stores flourished, and Kresge changed its name to Kmart Corporation in $1977 .^{37}$ By 1990, Kmart had overtaken Sears as the largest retailer in the United States. ${ }^{38}$ The person in charge when Kmart reached this retailing pinnacle was Joe Antonini, who began his career with Kmart as an assistant store manager in $1964 . .^{39}$ He worked his way up to president of the apparel division in 1984, where he successfully introduced a more

36. KMART CORPORATION, FORM 10-K ANNUAL REPORT FOR YEAR ENDED JAN. 31, 19901 (1990).

37. For a short history of Kmart, see Arthur Markowitz, 30 Years of Kmart, 1962-1992: A Historical Overview, DisCOUNT STORE NEWS, Feb. 17, 1992, at 40.

38. Christina Duff, Blue-Light Blues: Kmart's Dowdy Stores Get a Snazzy Face Lift, But Problems Linger, WALL ST. J., Nov. 5, 1993, at A1.

39. For a description of Antonini's rise through the ranks of Kmart, see Isadore Barmash, $K$ Mart's Heir Apparent: Joseph E. Antonini; $A$ Discounter Who Counts on Consumer Research, N.Y. TIMES, Dec. 21, 1986, \& 3, at 6. 
fashionable line of women's clothing using actress Jaclyn Smith as a spokeswoman. ${ }^{40}$ Antonini was elevated to the offices of President and Chief Operating Officer in $1986^{41}$ and named Chairman and Chief Executive Officer in $1987 .^{42}$

In his first letter to shareholders in Kmart's 1987 Annual Report, Antonini reported record sales and earnings for the previous year but conceded that, despite the records, Kmart's "sales plans were not met."43 Antonini then described "a number of important programs to improve the sales and profitability of the $\mathbb{K}$ mart discount department store business and to make Kmart the store of choice among shoppers in America." 44 In addition to internal restructuring and increased advertising, Antonini announced "a heavy capital investment in a number of retail automation programs, the most important of which is the installation of Point-of-Sale systems in our stores." 45 The goal of this automation was to improve inventory control and decrease labor costs, something that Kmart's main competitor Wal-Mart had already achieved. ${ }^{46}$ Despite extensive efforts to automate during Antonini's tenure, ${ }^{47} \mathrm{Kmart}$ 's inventory control problems persisted and were cited by observers as one of the primary causes of Antonini's downfall. ${ }^{48}$

The other primary concern for Antonini relating to Kmart's discount store operations was the age and condition of the stores themselves. When Antonini assumed the helm, the average age of the approximately $2,200 \mathrm{Kmart}$ discount stores was fifteen years. ${ }^{49}$

40. Duff, supra note 38 , at A4.

41. Jacob M. Schlesinger, K Mart Names Joseph Antonini To President's Post, WALL ST. J., Aug. 20, 1986, at 22.

42. KMART CORPORATION, 1988 PROXY STATEMENT 6 n.1 [hereinafter all Kmart Proxy Statements will be cited as [YEAR] PROXY STATEMENT].

43. KMART CORPORATION, 1987 ANNUAL REPORT TO SHAREHOLDERS 2 [hereinafter all Kmart Annual Reports will be cited as [YEAR] ANNUAL REPORT].

44. Id. at 2-3.

45. Id at 4.

46. Duff \& Ortega, supra note 1 , at A1.

47. See, e.g., 1990 ANNUAL REPORT, supra note 43 , at 8 (reporting on the installation of point-of-sale scanning and satellite systems in Kmart stores between mid-1986 and 1990); 1991 ANNUAL REPORT, supra note 43, at 2 (describing Kmart's "Partners in Merchandise Flow" initiative, which "involves state-of-the-art just-in-time merchandise delivery and Electronic Data Interchange with ... key vendors").

48. See, e.g., Howes, supra note 8 (listing "[o]perational miscues in merchandising and inventory controls" as one of three "nagging problems [that] brought down Antonini"); Neuborne, supra note 5, at 1B (listing "[i]nventory glitches" as one of four reasons "[w]hy Antonini is out").

49. Angela G. King, Kmart Tries to Remodel Its Image, DETROIT NEws, Dec. 12, 1993, at $1 \mathrm{D}$. 
Many of those stores had "water-warped floors, broken light fixtures, shelves placed too close together and cheap displays set in the middle of aisles." 50 As of early 1990-shortly after Antonini announced a "renewal program" to relocate, expand or refurbish virtually all existing Kmart discounts stores in the United States-only ten percent of Kmart stores were less than three years old while more than forty percent of stores at both Target and Wal-Mart were less than three years old. ${ }^{51}$

Antonini's original renewal plan called for Kmart to relocate 280 stores, expand 620 stores, refurbish 1,260 stores, and close thirty stores at a cost of approximately $\$ 2.3$ billion. ${ }^{52}$ In January 1994, the board of directors revised the renewal program to provide for relocation of an additional 500 stores previously slated for expansion or refurbishment after deciding that larger-format discount stores would be more productive and competitive than the smaller stores contemplated by the original renewal plan. ${ }^{53}$ The costs of the renewal program escalated to over $\$ 3.5$ billion. ${ }^{54}$

Despite Antonini's efforts to improve Kmart's discount stores, same-store sales at Kmart discount stores rose an average of only three percent during Antonini's first four years at the helm, as compared to Wal-Mart's average of twenty percent. ${ }^{55}$ One retail economist commented that "Wal-Mart is eating Kmart's breakfast, lunch, dinner and midnight snack.",56

In addition to the problems of inventory control and store renewal in the discount store operations, Antonini struggled throughout his tenure to develop Kmart's specialty retail operations. When Antonini came to power, Kmart owned three specialty retailers in the United States-Walden Book Company, Inc. (book stores), Pay

50. Duff \& Ortega, supra note 1, at A1.

51. Kara Swisher, Attention, Shoppersl; Here Come the Big, Flashy Discount Chains, WASH. POST, Aug. 11, 1991, at H1. In an interview shortly after his ouster from the company, Antonini recalled the first years of his tenure, saying: "We had an old base of stores. Target and Wal-Mart were opening new stores next to us. That's the difference. It's a deja vu for us, 15 and 20 years ago when we were opening new stores against our competition." Antonini talks back, DiSCOUNT STORE NEWS, Apr. 3, 1995, at 43.

52. 1989 ANNUAL REPORT, supra note 43, at 7.

53. 1995 ANNUAL REPORT, supra note 43, at 19.

54. 1993 ANNUAL REPORT, supra note 43, at H9. As of the 1995 Annual Meeting, Kmart had renovated about $70 \%$ of its stores. Angela G. King, Kmart Meeting Frustrates Investors; Firm Resurrects Blue-Light Special, Fails to Pick New Leader, DETROIT NEWS, May 24, 1995, at C1.

55. Duff, supra note 38 , at A4.

56. White, supra note 2, at D1-D2. 
Less Drug Stores Northwest, Inc. (super drug stores), and Builders Square, Inc. (home improvement stores). ${ }^{57}$ Kmart also owned Bargain Harold's Discount Limited, a Canadian retailer. ${ }^{58}$ Moreover in $1987 \mathrm{Kmart}$ entered into joint ventures with Bruno's, Inc., a leading food retailer in the Southeast United States, to develop a combination discount and grocery store called "American Fare" and with Makro, Inc., owner of four warehouse clubs in Cincinnati, Washington, D.C., Philadelphia, and Atlanta, to sell groceries and general merchandise. ${ }^{59}$ Finally, Kmart owned substantial equity investments in subsidiaries of Melville Corporation, which operated Kmart's domestic footwear departments, and in Coles Myer Ltd., the largest retailer in Australia. ${ }^{60}$

Just months before Antonini's ascension to the top posts at Kmart, his predecessor, Bernard Fauber, had cited "saner diversification" as one of the keys to Kmart's future success. ${ }^{61}$ But upon assuming the top posts, Antonini seized on the vision of creating a combination discount and specialty retailer by developing and acquiring other specialty retailers. In March 1988, Kmart purchased a fifty-one percent share of $\mathrm{Makro}^{62}$ and took full ownership a year later, when Kmart purchased PACE Membership Warehouse, Inc. and announced plans to convert all Makro stores into Pace Warehouse Clubs. ${ }^{63}$ In the fall of 1988 , Kmart opened two Office Square stores in the Chicago area. ${ }^{64}$ Office Square, a warehouse office supply business, grew to five stores before being sold to OfficeMax, Inc., which subsequently was acquired by Kmart. ${ }^{65}$ In January 1989, Kmart opened the first American Fare store in Atlanta

57. 1987 ANNUAL REPORT, supra note 43, at 19-20.

58. Id. at 20. Eight experimental Bargain Harold's stores in upstate New York were closed in 1987. Id. Kmart eventually sold Bargain Harold's in October 1990. 1994 PROXY STATEMENT, supra note 42 , at V-29.

59. 1987 ANNUAL REPORT, supra note 43, at 22.

60. Id. at 21.

61. Harlan S. Byrne, New Look at Kmart-The Retailer Goes Upscale And Its Earnings Follow Suit, BARRON's, May 11, 1987, at 8.

62. 1988 ANNUAL REPORT, supra note 43 , at 4.

63. 1989 ANNUAL REPORT, supra note 43, at 18. Pace sold substantialiy all of its assets to Sam's Club, a division of Wal-Mart, in January 1994. 1993 ANNUAL REPORT, supra note 43 , at 6 .

64. 1988 ANNUAL REPORT, supra note 43, at 4-5.

65. 1990 ANNUAL REPORT, supra note 43, at 22 (stating that in November 1990, Kmart acquired a $21.6 \%$ equity interest in OfficeMax, which previously had acquired all five Office Square stores, and Kmart had the right to acquire additional equity in OfficeMax under certain conditions); 1991 ANNUAL REPORT, supra note 43, at 25 (stating that Kmart increased its ownership in OfficeMax, Inc. to $93 \%$ in November 1991). 
and had plans for another in Charlotte, North Carolina. ${ }^{66}$ Kmart viewed these stores as "laboratories for developing a working food and general merchandise combination concept," ${ }^{67}$ and eventually converted them into Super Kmart Centers, a format combining the traditional Kmart discount store with a supermarket's food offerings. ${ }^{68}$ Kmart opened two Sports Giant stores in the Detroit metropolitan area in 1989.69 In March 1990, Kmart acquired The Sports Authority, Inc., an operator of a chain of eight large-format sporting goods stores, ${ }^{70}$ and later that year converted the Sports Giant stores into Sports Authority stores. ${ }^{71}$ In 1992, Kmart added the Borders Inc. book store chain in the United States, ${ }^{72}$ six discount stores in the Czech Republic, and seven discount stores in Slovakia. ${ }^{73}$ Kmart further expanded its international operations in 1994, opening new discount stores in Mexico and Singapore. ${ }^{74}$ Antonini's vision for Kmart apparently would have dotted the world with Kmart Power Centers-shopping centers featuring Kmart discount stores surrounded by Kmart-owned specialty stores, including PACE Membership Warehouse, Builders Square, PayLess Drug Store, Waldenbooks, The Sports Authority, OfficeMax, and Borders. ${ }^{75}$

Antonini's efforts to automate and renew Kmart's discount stores and expand and improve Kmart's specialty stores required significant amounts of capital. Contending that Kmart's common stock was undervalued, Antonini announced a plan in January 1994 to raise capital by creating and issuing separate classes of common stock whose terms would be tied to four of Kmart's specialty retail subsidiaries: The Sports Authority, Inc.; Builders Square, Inc.; Borders Group Inc. ${ }^{76}$ and OfficeMax, Inc. ${ }^{77}$ The proposal was

66. 1989 ANNUAL REPORT, supra note 43 , at 36 .

67. Id. at 12 .

68. 1992 ANNUAL REPORT, supra note 43, at 15. On subsequent developments with Super Kmarts, see Future of Super K Ripening for Kmart, DISCOUNT STORE NEWS, Mar. 20,1995 , at 31 .

69. 1989 ANNUAI REPORT, supra note 43 , at 5 .

70. Id.

71. 1990 ANNUAL REPORT, supra note 43 , at 10-11.

72. 1992 ANNUAL REPORT, supra note 43, at 26.

73. Id. at 6 .

74. 1994 ANNUAL REPORT, supra note 43, at 9.

75. 1992 ANNUAL REPORT, supra note 43, at 11.

76. Formerly Borders-Walden Inc., it included Borders, WaldenBooks, and Planet Music. Kmart Restructures Unit, Names Two Top Officials, WALl ST. J., Nov. 30, 1994, at B4.

77. Susan Tompor, Stock Plan Creates a New Kmart: Four Spinoffs Carry Risk For Retailer, Shareholders, DETROIT NEwS, Jan. 6, 1994, at C1. 
known as the "targeted stock proposal." "Targeted stock" is the name given by Wall Street bankers to a separate class or series of a company's common stock with returns tied to the performance of a certain subsidiary or other division of the company. ${ }^{78}$

Under the terms of the targeted stock proposal, shareholders were asked to authorize the amendment of Kmart's Restated Articles of Incorporation to provide for the issuance of shares of common stock in series to be created by the board of directors. Each of the series would be common stock of Kmart but would be designed to reflect separately the performance of a specialty retail subsidiary. The common stock outstanding at the time the targeted stock was to be issued also would constitute Kmart common stock, and would reflect Kmart's discount stores, any retained interest in the specialty retail subsidiaries (Kmart intended to retain about seventy to eighty percent interest in each subsidiary), and any other businesses of Kmart. The timing, sequence, and size of each offering of targeted stock would be determined by the board of directors without further vote of the shareholders. ${ }^{79}$

By the time Antonini announced the targeted stock proposal, investors and analysts had already begun to suggest that Kmart's foray into specialty retailing was a mistake and that Kmart should sell all of its specialty retail holdings. ${ }^{80}$ Shortly after announcement of the targeted stock proposal, SWIB issued a statement urging shareholders to vote against the targeted stock proposal and against five incumbent Kmart directors who were up for reelection. ${ }^{81}$ SWIB criticized Kmart's performance during Antonini's tenure and argued that Kmart's acquisition of specialty retail stores had "distracted Kmart from its core discount business." 82 SWIB's opposition to the targeted stock proposal was quickly joined by other investors. ${ }^{83}$

78. For short but useful discussions of targeted stock, see Lyn Perlmuth, On Target, INSTITUTIONAL INVESTOR, July 1, 1995, available in WESTLAW, Allnews Database, 1995 WL 10026304; Jennifer Reingold, Heartburn, FIN. WORLD, September 26, 1995, available in WESTLAW, Allnews Database, 1995 WL 8083296.

79. 1994 PROXY STATEMENT, supra note 42, at 45-82.

80. See, e.g., King, supra note 49, at $1 \mathrm{D}$.

81. Christina Duff, Pension Fund Calls on Kmart's Holders To Reject Plan for New Classes of Stock, WALL ST. J., May 10, 1994, at A2.

82. Id.

83. Christina Duff, Kmart Investor Joins Opposition To Stock Plan, WALL ST. J., June 1, 1994, at A4 (College Retirement Equities Fund); Kmart Stock Plan Opposed, N.Y. TIMES, June 3, 1994, at D5 (California Public Employees' Retirement System and the New York City pension fund); Stephanie Strom, Textile Union Opposes Kmart Stock Issue, N.Y. Times, May 19, 1994, at D5 (pension funds of Amalgamated Clothing and Textile Workers 
Also after the announcement of the targeted stock proposal, both Moody's Investors Service Inc. ${ }^{84}$ and Standard \& Poor's Ratings Group $^{85}$ lowered their ratings of Kmart outstanding indebtedness because of concern over the profitability of Kmart's discount stores. In a particularly pointed statement, Standard \& Poors noted that Kmart's financial performance had been "slowly deteriorating since $1988, " 86$ the first full year of Antonini's tenure.

But both Kmart and its investment bankers felt the targeted stock proposal was the best way to maximize shareholder value, even after shareholders rejected the idea. ${ }^{87}$ Furthermore, even among those who opposed the proposal, reasons for the opposition differed. Some investors wanted Kmart to sell all of the specialty retailing operations, arguing that the specialty retailers were a distraction from Kmart's main business of discount retailing. Other investors wanted the company to create a tax-free spin-off of the specialty retailers to shareholders. Still others believed that the stock market would not value targeted stock appropriately and wanted Kmart to sell its own common stock instead. Institutional investors may have opposed the proposal because they were not allowed to vote to authorize so many new shares for issuance or because they could not vote for a plan that allowed employees to buy stock at a discount. Finally, some investors appeared to oppose the proposal simply to cast an emotional vote against Kmart's management. 88

The fact that Kmart's proposal for raising money by issuing securities to the public came before the shareholders was unusual, and as noted above, its defeat by shareholders was "one of the most astonishing investor rebellions in corporate history." 89 The shareholder vote was unusual because most corporations access the capital markets through the issuance of additional securities upon approval of the board of directors only. Kmart could have taken this

Union).

84. Business Briefs: Despite Kmart's Renovations, Moody's Again Lowers Debt Ratings of Retailer, WALL ST. J., Mar. 9, 1994, at B4.

85. Kmart Corp. Debt Totaling $\$ 3.7$ Billion Downgraded by S\&P, WALL ST. J., April 19,1994 , at B2.

86. Id.

87. Bankers Undaunted, supra note 2, at 1; $c f$. Don Longo, When the Subject is Kmart, What Happens to Objectivity?, DISCOUNT STORE NEWS, July 18, 1994, at 12 ("Antonini's plan to fully unlock the inherent value of these specialty retail units while at the same time raising capital for accelerating the modernization of the core discount store division is sound.").

88. Bankers Undaunted, supra note 2, at 46.

89. Woodruff \& Dobrzynski, supra note 2 , at 42. 
course, except that Kmart's management perceived the trading price of Kmart common stock to be below its "true" value. Antonini and the board, therefore, followed the counsel of investment bankers at Lehman Brothers, who advised that Kmart could maximize the proceeds of a public offering by issuing targeted stock. Because Kmart's charter did not allow for the issuance of targeted stock, Kmart was required to seek approval of shareholders to amend the corporate charter before accessing the capital markets.

Investor rejection of the targeted stock proposal was shocking because shareholder approval of management-proposed charter amendments normally is pro forma. ${ }^{90}$ In this instance, the rules regulating voting on the amendment were contained in the Michigan Business Corporation Act, which requires "the affirmative vote of a majority of the outstanding shares" for approval of any charter amendment. ${ }^{91}$ Of the 416 million shares outstanding, 108.6 million shares $(26.1 \%$ of the total shares outstanding) were voted against the proposal, including many of the 19 million shares held by employees. $^{92}$ An additional twenty-eight percent of the total outstanding shares abstained. ${ }^{93}$ When the voting was over, John Wilcox, chairman of Georgeson \& Co., Kmart's proxy solicitor, took the prize for understatement, saying: "It was worse than we predicted." 94

90. See Frank H. EASTERBROOK \& DANIEL R. FISCHEL, THE ECONOMIC STRUCTURE OF CORPORATE LAW 83 (1991) ("[M]anagers' recommendations on fundamental corporate changes, amendments of bylaws, or other matters are routinely followed. . . ."); cf. David S. Freeman, Shark Repellant Charter and Bylaw Provisions, 16 J. CORP. L. 491, 519 n.13 (1991) ("Although historically almost all shark repellant charter proposals have been accepted by shareholders, the high success rate is attributable in part to prescreening and active proxy solicitation by the proposing company."); Jonathan $R$. Macey, Corporate Law and Corporate Governance: A Contractual Perspective, $18 \mathrm{~J}$. CoRP. L. 185, 191 (1993) (arguing that shareholders face significant obstacles in opposing management-proposed charter amendments because shareholders are "rationally ignorant" and because "insiders who want to enact charter amendments that reduce shareholder wealth can bundle these welfare-reducing amendments together with other unrelated proposals which shareholders favor"). Although institutional investors have become more active and successful in passing shareholder proposals, see William W. Bratton \& Joseph A. McCahery, Regulatory Competition, Regulatory Capture, and Corporate Self-Regulation, 73 N.C. L. REV. 1861, 1906-10 (1995), there is no evidence that this activism has translated into more rejections of management proposals.

91. MICH. COMP. LAWS ANN. § 450.1611 (West 1994). The same rule applies to Delaware corporations, per DEL. CODE ANN. tit. 8, \& 242 (1995), and also in states that have adopted MODÉL BUSINESS CORP. ACT $\$ 10.03$ (1984).

92. Woodruff and Dobrzynski, supra note 2, at 42.

93. Id.

94. Id. 
Immediately after the proxy contest, SWIB representative James Severance seemed to gloat: "We wanted to force this company to rethink their direction. ... Either you replace the strategy or the strategist."95 But Antonini seemed intent on accomplishing the substance of the targeted stock proposal without shareholder approval. ${ }^{96}$ He suggested that the vote was a "misunderstanding," while outside director (later Chairman) Donald Perkins labelled it "a communications problem."97 Antonini hired Professor John Pound of the Kennedy School of Government at Harvard to act as an intermediary for Kmart in its relations with about twenty institutional investors that together held more than fifteen percent of Kmart stock. Unfortunately for Antonini, after conducting interviews with representatives of each of the investors, Pound concluded that the institutions all wanted $\mathrm{Kmart}$ to sell the specialty retail subsidiaries. ${ }^{98}$

Antonini listened. In November 1994, Kmart executed highly successful initial public offerings of OfficeMax ( $\$ 642$ million $)^{99}$ and The Sports Authority ( $\$ 233.7$ million) $)^{100}$ and sold its entire stake in Coles Myer for approximately $\$ 928$ million. ${ }^{101}$ In addition, Kmart announced its intention to sell the Borders Group ${ }^{102}$ and Builders Square. ${ }^{103}$

Also after the proxy contest, Antonini appointed four new executive vice presidents from outside the company, ${ }^{104}$ perhaps in

95. $I d$.

96. $I d$.

97. $I d$.

98. Judith H. Dobrzynski, Attention, Kmart Stockholders: Victory, BUS. WK., Sept. 5, 1994 , at 8.

99. Kmart Spins Off OfficeMax Division, N.Y. Times, Nov. 3, 1994, at D5.

100. Sports Authority's Stock Offering Soars, N.Y. TIMES, Nov. 19, 1994, at 44 (noting that The Sports Authority's stock soared to $\$ 24$ after being offered at $\$ 19$ on the New York Stock Exchange). On subsequent problems at The Sports Authority, see David A. Markiewicz, Life After Kmart: Without Retailer, It Isn't Smooth Sailing for Sports Authority, DETROIT NEws, May 7, 1995, at 1D.

101. Kmart Sells Stake in Coles Myer, WALL ST. J., Nov. 7, 1994, at B9.

102. New Issues Pipeline: Borders Group Inc., INVESTORS' BUS. DAILY, Dec. 1, 1994, at A6. Kmart subsequently sold all but $13 \%$ of the shares in Borders in an initial public offering, New Securities Issues, WALL ST. J., May 25, 1995, at B9, and later agreed to sell all of its remaining shares back to Borders. Borders Group Inc.: Bookseller Agrees to Buy Kmart's Remaining Stake, WALL ST. J., July 18, 1994, at B4.

103. Can Kmart's Builders Square Stand On Its Own? INVESTOR's Bus. DAILY, Jan. 25,1995 , at A4.

104. Christina Duff, Kmart Taps Chinni, a Macy Veteran, To Help Revitalize Its Merchandising, WALL ST. J., Feb. 16, 1995, at B4 (discussing the appointment of Charles Chinni to direct merchandising); New Blood: Kmart Corp. Has Brought in Three Executives to Help Reform the Company, DETROIT NEwS, Nov. 23, 1994, at 3E (discussing 
an attempt to answer critics who claimed that he was too loyal to longtime Kmart employees who could not get the job done. ${ }^{105}$ Despite Antonini's efforts to respond, shareholders demanded his replacement and the board of directors ultimately acceded to that demand. ${ }^{106}$

In retrospect, Antonini's Kmart-despite many positive developments-seems to have had two distinguishing characteristics: (1) Antonini's inability to establish a business strategy and maintain $\mathrm{it}^{107}$ and (2) incessant shareholder carping about KKmart's performance. ${ }^{108}$ These problems, of course, were interdependent. Shareholders typically do not complain when a company is being managed well and making inroads in its product markets, and Kmart's shareholders were no exception. They complained because Kmart was losing the discount store competition to Wal-Mart and Target. From the time Antonini took control in 1987 to the time of his resignation in 1995, Kmart's market share of total discount retail sales

the appointment of Marvin P. Rich to head strategic planning, finance, and administration, Kenneth Watson to head marketing and product development, and Ronald J. Floto to run Super Kmart centers).

105. Howes, supra note 8 , at $* 4$.

106. See supra notes 4-13 and accompanying text.

107. More than six years after Antonini took control, one commentator declared, "Unfortunately, changing direction is a habit at Kmart." James B. Treece, Kmart: Slick Moves-Or Running in Place?, Bus. WK., Jan. 17, 1994, at 28. Interestingly, Antonini was asked shortly after he resigned what advice he would give to business students. He responded, "You have to have a strategy, you have to have a game plan, it has to be long term and you have to stick to it." Daniel Howes, Antonini Says He Failed to Heed Kmart Shareholders, DETROIT NEwS, Mar. 24, 1995, at A1.

108. From the foregoing account of the targeted stock proposal, shareholder pressure on Antonini is evident in the last year or so of his tenure, but shareholders became active in Kmart early in Antonini's reign. In 1990 Kmart was targeted for shareholder activism by the United Shareholders Association, a shareholder-rights group formed by T. Boone Pickens. Melinda Wilson, 'Pension Power' Targets Kmart, CRAIN's DET. BuS., Oct. 1, 1990, at 1. At Kmart's 1990 Annual Meeting, three institutional investors made proposals recommending corporate governance reforms relating to confidential proxy voting, staggered terms for board members, and Kmart's poison pill. 1990 PROXY STATEMENT, supra note 42 , at 11-16. All three proposals were nonbinding and were opposed by Kmart's board of directors. Only the proposal relating to the poison pill passed. Wilson, supra at 1. At Kmart's 1995 Annual Meeting, 61\% of Kmart's shareholders voted in favor of a nonbinding proposal calling for annual elections of directors. Kmart's board of directors is currently staggered. Kmart Says Board Is Close To Selecting a New CEO, WALL ST. J., May 24, 1995, at B4. Kmart's board, under pressure from SWIB, later agreed to support a proposal to shorten the term of the poison pill by three years, and Kmart's shareholders approved such a proposal at the 1991 Annual Meeting. 1991 PROXY STATEMENT, supra note 42, at 12; Kmart Holders Vote To Shorten the Term Of Poison-Pill Plan, WALL ST. J.; May 30, 1991, at B10. 
dropped from $34.5 \%$ to $22.7 \%$, while Wal-Mart's rose from $20.1 \%$ to $41.6 \%{ }^{109}$

A focal point of shareholders' concerns, especially during the contest over the targeted stock proposal, was the price of Kmart's stock. ${ }^{110}$ During that contest, SWIB took out an advertisement in The Wall Street Journal comparing the average annual shareholder return of Kmart to Wal-Mart over the previous five years. ${ }^{11}$ On the day before Antonini's resignation, Kmart shares closed at twelve dollars per share-significantly less than the price when he took over. $^{112}$

On the other hand, Antonini's inability to maintain a consistent business strategy seemed to stem at least partially from his constant attempts to placate shareholders. Antonini's inability to stabilize Kmart's course was evidenced by the seemingly frantic pace of the acquisition and sale of specialty retailers described above, by numerous studies, reviews, and task forces he ordered apparently to defuse shareholder criticism, ${ }^{113}$ and by the frequent reshuffling of his management team. ${ }^{114}$ Inc.).

109. Duff \& Ortega, supra note 1, at A6 (citing statistics from Tactical Retail Solutions

110. See, e.g., Daniel Howes, 2 Investor Groups Join Kmart Opposition, DETROIT NEwS, June 1, 1994, at E1 (stating that College Retirement Equities Fund opposed the targeted stock proposal because of Kmart's "significant long-term decline in market share, profitability, operating earnings and share price").

111. State of Wisconsin Investment Board, Advertisement, WALL ST. J., May 24, 1994, at $\mathrm{C} 13$.

112. Antonini took office on October 1,1987 , and Kmart's stock was trading at $\$ 403 / 8$ per share. At the time, Kmart had approximately 202 million shares outstanding. KMART CORPORATION, FORM 10-Q QUARTERLY REPORT FOR QUARTER ENDED OCTOBER 28, 1987 (number of shares as of November 13,1987). Kmart announced a two-for-one stock split in 1992. At the time of the split, Kmart's stock was trading at $\$ 537 / 8$. Laura Liebeck, Kmart Hits 30 With Upbeat Earnings Report, DiSCOUNT STORE NEWS, Apr. 6, 1992, at 3. As of March 3, 1995, Kmart had nearly 459 million shares outstanding. 1995 PROXY STATEMENT, supra note 42, at 4.

113. After disappointing earnings in the first quarter of 1989 , for example, Antonini announced a study of Kmart's distribution capabilities to improve inventory control. Don Longo, Kmart's Aggressive Plans Call For \$40B Sales by 1995, DIsCOUNT STORE NEwS, June 5, 1989, at 81. At the 1994 Annual Meeting, while the votes against the targeted stock proposal were being counted, Antonini announced the formation of a "task force" comprised of corporate officers to implement cost savings. Laura Liebeck, Kmart Unveils Task Force to Ax $\$ 800 M$ in 2 yrs., DisCount STORE NEws, Dec. 5, 1994, at 3, 125. Even the board of directors seemed to adopt this strategy for placating shareholders. Upon Antonini's ouster as chairman, the board of directors announced a "strategic review" of Kmart's business, including "merchandising, leadership, financial policies and operational execution." Duff \& Lublin, supra note 5, at A3.

114. See supra note 104 and accompanying text. 
The picture that emerges shows Antonini torn between efforts to prove that his vision for Kmart ultimately would prevail in the marketplace and efforts to show shareholders and the financial press, in visible and tangible ways, that he was creating a company that could compete with Wal-Mart and Target. After his resignation, Antonini attributed his downfall to a failure to listen to investors, but he claimed that pressure from shareholders, "the New York media, the local media and the financial media ... was so great that it wouldn't allow us to do our job."115 'These comments reveal the conflict that Antonini's actions exhibited. He could not simultaneously respond to investors and ignore them.

\section{KMART's CoRporate Governance Problem AND How THE CORPORATE GOVERNANCE SYSTEM DEALT WITH IT}

Berle and Means defined the central problem of corporate governance as the separation of ownership and control. ${ }^{116}$ Ownership rests in shareholders, control in managers. ${ }^{117}$ Berle and Means observed the divergence of interests of owners and managers and asked the question that has dominated corporate law ever since: " $[\mathrm{H}]$ ave we any justification for assuming that those in control of a modern corporation will also choose to operate it in the interests of the owners?"118 The answer to that question, they argued, depends on "the degree to which the self-interest of those in control may run parallel to the interests of ownership and, insofar as they differ, on the checks on the use of power which may be established by political, economic, or social conditions."119 The corporate governance system aims to secure, to the extent practicable, the alignment of interests of owners and managers.

According to Berle and Means, this alignment of interests was secured in the nineteenth century American corporation by a "series of protections"120 aimed at shielding shareholders from abuse. ${ }^{121}$ But as those protections were eroded, shareholders were forced to

115. Howes, supra note 107 , at A1.

116. ADOLF A. BERLE \& GARDINER C. MEANS, THE MODERN CORPORATION AND PRIVATE PROPERTY 112-16 (revised ed. 1968).

117. Berle and Means describe these two groups in chapters entitled "The Dispersion of Stock Ownership" and "The Evolution of Control." Id. at 47-111.

118. Id. at 113.

119. Id. at 113-14.

120. Id at 122 .

121. Id. at $128-40$. 
look elsewhere for assistance. ${ }^{122}$ Berle and Means argued that the only protection against managerial abuse besides a shareholder revolt was the fact that companies eventually might need to access the capital markets, thus requiring managers to act in a manner that would encourage future investors to purchase the company's securities. $^{123}$

Berle and Means thus considered two possible constraints on managerial abuse: internal constraints (the "series of protections") $)^{124}$ and external constraints (capital markets). ${ }^{125}$ The story they told showed corporate law evolving inexorably away from internal constraints and relying more on external constraints. ${ }^{126}$

The work of Berle and Means inspired a generation of corporate law scholars to search for additional internal constraints that might improve the corporate governance system. ${ }^{127}$ During the 1980 s, a powerful new paradigm largely displaced scholarship in the Berle and Means tradition. Usually referred to as the "contractarian model," contracts." 129 In the most prominent formulation of the contractarian model, Frank Easterbrook and Daniel Fischel describe this nexus of contracts as "a set of implicit and explicit contracts" among "those who associate voluntarily in the corporation," 130 including shareholders, managers, creditors, and employees.

Although the nexus-of-contracts metaphor may have lost some of its currency, ${ }^{131}$ the description "contractarian" now extends to

122. Berle and Means told their erosion story through a series of chapters under the heading "Regrouping of Rights: Relative legal position of ownership and control." Id. at 119-252.

123. Id. at 131-33.

124. Id. at $122-28$.

125. Id. at 131-33.

126. Id. at 119-40. For a skeptical view of the Berle and Means story, see WALTER WERNER \& STEVEN T. SMITH, WALL STREET 113-29 (1991).

127. For an excellent description of the evolution of corporate scholarship from Berle and Means to present, see Edward B. Rock, America's Fascination With German Corporate Governance 2-12 (U. Penn. Inst. for Law \& Econ. Discussion Paper No. 164, 1994); see also Jason S. Johnston, The Influence of The Nature of the Firm on the Theory of Corporate Law, 18 J. CORP. L. 213, 221-32 (1993)(discussing the evolution in corporate law scholarship).

128. For an introduction to the contractarian model, see Michael Klausner, Corporations, Corporate Law, and Networks of Contracts, 81 VA. L. REV. 757, 767-72 (1995).

129. Michael C. Jensen \& William H. Meckling, Theory of the Firm: Managerial Behavior, Agency Costs, and Ownership Structure, 3 J. FIN. ECON. 305, 310-11 (1976).

130. EASTERBROOK \& FISCHEL, supra note 90, at 12.

131. See William W. Bratton, The Economic Structure of the Post-Contractual Corporation, 87 Nw. U. L. REV. 180, 191-98 (1992) (arguing that Easterbrook and Fischel 
matters beyond the initial metaphor. Like Berle and Means and their intellectual descendants, contractarians acknowledge the separation of ownership and control, but conceptualize the separation in terms of the now-familiar problem of "agency costs."132 Under the contractarian model, the purpose of the corporate governance system is the minimization of agency costs. ${ }^{133}$ Contractarians view external constraints-including not only capital markets, but also other markets-as relatively effective methods of managerial discipline and generally oppose efforts to impose additional internal constraints on managers. ${ }^{134}$

Although the contractarian approach to corporate law has been challenged vigorously, ${ }^{135}$ this Article does not join in that challenge. Indeed, the structure of the following analysis is explicitly contractarian. ${ }^{136}$ The purpose of this Article is more modest: it is to determine whether the corporate governance system adequately addresses Kmart's corporate governance problem.

\section{A. Kmart's Corporate Governance Problem}

As noted above, the directors of a corporation face two distinct problems with respect to their efforts to control managers: "moral hazard" and "adverse selection." Moral hazard arises from the inability of directors to control the actions of the managers they hire and may result in shirking or in the diversion of corporate assets. Adverse selection arises from the inability of directors properly to

retreated from the nexus-of-contracts theory because of shortcomings revealed in the late 1980s).

132. Jensen \& Meckling, supra note 129 , at 308-10.

133. See, e.g., EASTERBROOK \& FISCHEL, supra note 90, at 10; OLIVER E. WILLIAMSON, THE ECONOMIC INSTITUTIONS OF CAPITALISM 298-325 (1985).

134. Bratton describes this as the contractarian "presumption against regulation." Bratton, supra note 131 , at $186-87$.

135. See, e.g., MERRITt B. FoX, FinANCE AND INDUSTRIal PERFormanCE IN A DYNAMIC ECONOMY 142-43 (1987); Victor Brudney, Corporate Governance, Agency Costs, and the Rhetoric of Contract, 85 COLUM. L. REV. 1403, 1411-27 (1985); Lynne L. Dallas, Two Models of Corporate Governance: Beyond Berle and Means, 22 U. MICH. J.L. REFORM 19, $24-29$ (1988); Roberta S. Karmel, Implications of the Stakeholder Model, 61 GEO. WASH. L. REV. 1156, 1156-58 (1993); Martin Lipton \& Steven A. Rosenblum, A New System of Corporate Governance: The Quinquennial Election of Directors, $58 \mathrm{U}$. CHI. L. REV. 187, 190-202 (1991); David Millon, Communitarians, Contractarians, and the Crisis in Corporate Law, 50 WASH. \& LEE L. REV. 1373, 1377-90 (1993).

136. The analysis assumes, for example, that corporations exist for the benefit of the shareholders, that managers of corporations will favor their own interests over those of the shareholders, and that the goal of the corporate governance system is to align the interests of managers with shareholders. 
judge the competence of the managers they hire and may result in the hiring of incompetent managers.

Kmart long performed below investor expectations, but no one accused Antonini of managerial abuse: there were no allegations of extravagant executive perquisites as was the case with Ross Johnson at RJR Nabisco; ${ }^{137}$ Antonini appears to have been tireless in his efforts to promote the company (i.e., no shirking); and there were no accusations of theft, fraud, or diversion of corporate opportunities. Kmart, therefore, did not appear to suffer the consequences of the moral hazard problem. Kmart either was faced with managerial incompetence, an adverse selection problem, or Antonini's ouster was an error. ${ }^{138}$

The evidence suggests that Kmart's shareholders viewed Antonini as incompetent. As described above, Kmart's shareholders complained both about Kmart's specialty retail strategy and about Antonini's inability to improve Kmart's discount operations. Viewed more generally, Kmart's shareholders lacked confidence both in Antonini's ability to formulate strategy (i.e., many shareholders did not approve of the specialty retail strategy) and in his ability to administer an approved strategy (i.e., although shareholders seemed to accept the need to update Kmart's discount stores, they did not believe that Antonini had implemented this strategy efficiently). Both as a strategist and as an administrator, therefore, Antonini was perceived as incompetent, and as noted above, the only cure for incompetence is replacement. It is possible that a manager could be competent as a strategist but not as an administrator, or vice versa. In such a circumstance, a company might elect to replace the manager only in the area of his or her incompetence (for example, by appointing another manager or the board of directors to perform that role) while retaining the manager to perform the other role. If Antonini had been perceived as a competent administrator, for

137. See Bryan BurRough \& JoHn Helyar, Barbarians at the Gate: The FAIL OF RJR NABISCO 92-97 (1990).

138. One might imagine a circumstance in which the board of directors replaces a competent manager (i.e., one whose performance meets shareholder expectations) for reasons that appear rational to the directors but are not value enhancing for the shareholders. For example, if an executive is particularly abrasive or condescending to the directors, the executive might be replaced with a more congenial personality. Although arguably rational from the directors' viewpoint, such action is not in the interests of the shareholders unless the executive's personality shortcomings translate into performance deficiencies. Indeed, given the understanding of incompetence employed herein, see supra note 17, it is fair to state that the replacement of any manager must be justified on grounds of incompetence or should be considered an error. 
example, the shareholders may have been satisfied when he acceded to their demands to sell the specialty retailers (i.e., when shareholders usurped his role as strategist). In the end, however, Antonini's agreement to change strategy was insufficient, and Kmart's shareholders caused Antonini's replacement as strategist and as administrator.

It is exceedingly difficult, and perhaps impossible, to judge whether the shareholders were correct, whether Antonini was in fact "incompetent" in either role, because there is no accepted standard by which managerial competence is measured. One might compare Antonini's business decisions with those of Sam Walton as a rough approximation of Antonini's competence as a strategist. ${ }^{139}$ But this analysis cannot account for the fact that no two companies are identical, and it does not measure Antonini's abilities as an administrator. In the case of Kmart, Antonini's strategic decisions were praised until Kmart performed below expectations. ${ }^{140}$ This might suggest that the decisions were bad, but it also might suggest that the execution was bad or that Kmart's disappointing performance was attributable to factors largely unrelated to Antonini, such as the location and condition of Kmart stores when Antonini inherited power. ${ }^{141}$

139. Cf. Khanna \& Poulsen, supra note 25 , at $924-38$ (comparing actions by managers of firms during the three years prior to filing for bankruptcy with actions by managers of firms that performed better in search of evidence of incompetence or self-serving behavior).

140. For example, oft-quoted industry analyst Kurt Barnard was quoted in February 1993 with regard to the possibilities for Kmart's specialty stores: “"The chains represent the right thing at the right time, done correctly... . Relatively low prices and a huge assortment--those are what make those category killers go." "Joln P. Cortez, Kmart Unleashes Its "Category Killer" Chains, ADVERTISING AGE, February 1, 1993, at S-4. Less than three months later, Barnard was touting the benefits of a spinoff of the specialty stores. Kmart Talk of Spinoff Continues Specialty Stores Are a Possibility, ATLANTA J. \& CoNST., May 23, 1993, at H8.

141. In a reminder of this fact, one commentator recently quoted an analyst discussing the state of Kmart when Antonini ascended to the top:

Said one analyst: "Sales growth [in 1986] was mostly attributable to the specialty store segment and not the traditional discount general merchandise category. Furthermore, much of this revenue growth comes as a result of an increase in specialty store revenue caused by acquisitions [Home Centers of America, Waldenbooks and Pay Less Drug Stores] being included for a full year in 1986, while only partially included in 1985."

This analyst also pointed out that Kmart experienced the lowest compounded growth over a five-year period (1982 to 1986) at $8 \%$; compared with Zayre at $20 \%$ and Wal-Mart at $31 \%$. Over the same five-year period, Kmart's net income declined $5.6 \%$. 
This is not to suggest that competence is irrelevant, but merely that it is difficult to measure. In addition, it serves as a cautionary note by admission of the possibility that Kmart may have had neither a moral hazard problem nor an adverse selection problem, but that perhaps Antonini's forced resignation was an error.

Fortunately, from a corporate governance perspective, the most interesting question is not whether Antonini was in fact incompetent-that would reveal only whether an error was committed in this instance-but instead whether the process by which Antonini's competence was evaluated was likely to maximize Kmart's expected value. In short, what matters is whether the corporate governance system effectively mediates competing views regarding managerial incompetence. Kmart's corporate governance problem, therefore, arose from the fact that some of Kmart's shareholders believed Antonini should be replaced. What the corporate governance system resolves is how much power those shareholders have to act on those beliefs.

\section{B. External Constraints on Managerial Behavior}

Berle and Means identified capital markets as a constraint on managerial abuse. Since Berle and Means, economists have argued that several additional market mechanisms constrain managerial behavior. Among those additional external constraints are the market for corporate control, product markets, and managerial labor markets, each of which is discussed below. ${ }^{142}$ The purpose of this section is not to catalog the myriad external constraints-that has been done effectively elsewhere ${ }^{143}$ - but rather to evaluate the possible effects of those constraints on the management of Kmart.

\section{Capital Markets}

In the contractarian paradigm, the role of capital markets in the corporate governance system is to provide managers with incentives to maximize stock values for shareholders. If managers fail to maximize stock values, they may forego portions of their compen-

Tony Lisanti, Can Kmart Return to Health, or Is It Reprising an Old Vision, DiscouNT STORE NEWS, Feb. 20, 1995, at 15.

142. Cf. Bratton \& McCahery, supra note 90, at 1866 (referring to these three markets collectively as the "market" strategy for solving the management-shareholder agency problem).

143. See, e.g., Henry N. Butler, The Contractual Theory of the Corporation, 11 GEO. MASON L. REV. 99, 110-20 (Summer 1989). 
sation that are based on stock price performance, they may be fired by the board of directors, or they may be replaced following a takeover by someone who expects to make money by purchasing the company and improving its performance. Whether capital markets are able to fulfill this monitoring role properly in the corporate governance system depends on whether the quality of management's performance is reflected accurately in the price of the corporation's stock. Management expert Peter Drucker has concluded that stock markets are not well-equipped to reflect managerial performance:

The stock market is surely the least reliable judge [of managerial performance] or, at best, only one judge and one that is subject to so many other influences that it is practically impossible to disentangle what, of the stock market appraisal, reflects the company's performance and what reflects caprice, affects the whims of securities analysts, short-term fashions and the general level of the economy and of the market. ... 144

Implicit in Drucker's indictment of capital markets are two criticisms of the ability of capital markets to reflect managerial performance accurately: (1) Capital markets are not efficient because stock prices reflect "caprice," "the whims of securities analysts," and "short-term fashions"; and (2) Even perfectly efficient capital markets would not be very good at judging managerial performance because stock prices are influenced by information on so many matters besides managerial performance, such as the general state of the economy and of the market. If valid, either of these criticisms of the ability of capital markets to reflect managerial performance, standing alone, would argue for reducing the corporate governance system's reliance on capital markets. Together, they form a powerful argument against the conception of capital markets in the contractarian paradigm.

Increasingly, the view that capital markets are inadequate measures of managerial performance is supported by financial economists, who frame the issue in terms of market efficiency. The Efficient Capital Markets Hypothesis (ECMH) is one of the most influential ideas to emerge from the theory of modern finance. ${ }^{145}$ The ECMH contemplates three forms of market efficiency:

144. MONKs \& MINNow, supra note 29, at 36 (quoting Private Letter from Peter F. Drucker to Robert Monks, June 17, 1993).

145. For an entertaining history of the development of the ECMH and related theories, including anecdotes about the primary academic proponents, see PETER L. BERNSTEIN, CAPITAL IDEAS (1992). 
"weak-form efficiency" occurs if current stock prices incorporate all information in past stock prices, so that an investor who knows only the pattern of past stock prices cannot consistently outperform the market; (2) "semistrong-form efficiency" occurs if current stock prices incorporate all publicly available information, so that an investor who knows only the pattern of past stock prices plus, for example, financial statements or news reports, cannot consistently outperform the market; and (3) "strong-form efficiency" occurs if current stock prices incorporate not only all publicly available information but all material information that is known to at least one investor, so that no investor can consistently outperform the market. ${ }^{146}$

These three forms of market efficiency all relate to the capacity of the capital markets to incorporate information in stock prices immediately so that no one may use the information to make excess profits. In other words, they are descriptions of different levels of "informational efficiency." Although it is widely accepted that some inefficiency must exist to induce investors to trade, ${ }^{148}$ considerable empirical evidence supports the weak and semistrong forms of informational market efficiency. ${ }^{149}$ In addition, the strong-form

146. For excellent introductions to the ECMH, see RICHARD A. BREALEY \& STEWART C. MYERS, PRINCIPLES OF CORPORATE FINANCE 287-310 (4th ed. 1991); STEPHEN A. ROSS ET AL., CORPORATE FINANCE 359-87 (3d ed. 1993).

147. See Ian Ayres, Back to Basics: Regulating How Corporations Speak to the Market, 77 VA. L. REV. 945, 968 (1991) ("The ECMH concerns whether a stock market is 'informationally' efficient: that is, whether the current market price immediately reflects different categories of existing information.").

148. See, e.g., Fischer Black, Noise, 41 J. Fin. 529, 530 (1986) ("If there is no noise trading, there will be very little trading in individual assets."); Sanford J. Grossman \& Joseph E. Stiglitz, On the Impossibility of Informationally Efficient Markets, 70 AM. ECON. REV. 393, 393 (1980) (stating that stock prices must vary from fundamental values enough to account for the marginal costs of information).

149. See, e.g., ROSS ET AL., supra note 146, at 372 ("Our view of the literature is that the evidence, taken as a whole, is strongly consistent with weak-form efficiency."); $i d$. at 376 ("Although there are exceptions, the event-study tests generally support the view that the market is semi-strong form . . . efficient."). Several recent studies of mutual funds examine with mixed results the ability of mutual fund managers to outperform the market. Compare Burton G. Malkiel, Returns from Investing in Equity Mutual Funds 1971 to 1991, 50 J. FiN. 549, 571 (1995) ("[T]his study of mutual funds does not provide any reason to abandon a belief that securities markets are remarkably efficient.") with William $N$. Goetzmann \& Roger G. Ibbotson, Do Winners Repeat? Patterns in Mutual Fund Return Behavior, 20 J. PORTFOLIO MGMT. 9, 9-10 (Winter 1994) (mutual funds with aboveaverage performance persist); Mark Grinblatt \& Sheridan Titman, The Persistence of Mutual Fund Performance, 47 J. FIN. 1977, 1983 (1992) (same); Darryll Hendricks et al., Hot Hands in Mutual Funds: Short-Run Persistence of Relative Performance, 1974-1988, 48 J. FIN. 93, 93-95 (1993) (same). 
efficiency theory has some empirical support, ${ }^{150}$ although the bulk of the evidence suggests that capital markets are not strong-form efficient. ${ }^{151}$

Just because share prices react immediately to information, however, does not mean that those reactions are accurate. ${ }^{152}$ Nevertheless, proponents of the ECMH believe that efficient markets not only incorporate information immediately, but also reflect rational expectations about the future value of securities. ${ }^{153}$ In other words, they believe that capital markets exhibit "fundamental-value efficiency."154 Lynn Stout recently noted, "During the 1970s and 1980 s, the notion that informational efficiency necessarily implies fundamental-value efficiency, and that stock market prices consequently provide accurate estimates of stocks' funclamental values, enjoyed great popularity."155 Financial economists now widely agree

150. See, e.g., Eugene F. Fama \& Kenneth R. French, Permanent and Temporary Components of Stock Prices, 96 J. POL. ECON. 246, 265-66 (1988) (showing that lower earnings lead to stock price declines a few days before the earnings are publicly announced).

151. See, e.g., Ross ET AL., supra note 146, at 381 (citing studies showing abnormal returns from insider trades and concluding that "strong-form efficiency does not seem to be substantiated by the evidence").

152. Cf. Donald C. Langevoort, Theories, Assumptions, and Securities Regulation: Market Efficiency Revisited, 140 U. PA. L. REV. 851, 856 (1992) ("If stock price behavior is completely and mindlessly arbitrary-a true random walk-statistical tests would demonstrate an absence of arbitrage opportunities. Prices would be unbiased in the sense that they would show no systematic tendency to be too high or too low."); Lawrence $\mathrm{H}$. Summers, Does the Stock Market Rationally Reflect Fundamental Values?, 41 J. FIN. 591, 599-600 (1986) (although "both theoretical and empirical considerations suggest the likelihood that market valuations differ frequently and substantially from fundamental values," Summers does not dispute the "central message of the huge literature on market efficiency," namely, "the supreme difficulty of earning abnormal returns making use only of publicly available information").

153. Langevoort, supra note 152, at 856-57. Langevoort observes:

Much of the efficient markets literature ... makes the ... claim that financial markets are built on rational expectations about asset values. The explicit or implicit assumption is that information impounded quickly in stock prices is nothing but information reasonably related to expectations about future values. Used in this way, it is entirely plausible to claim that prices reflect the most Id. rational possible assessment of present value.

154. For a recent discussion of the distinction between "informational efficiency" and "fundamental efficiency," with ample references to other sources, see Lynn A. Stout, Are Stock Markets Costly Casinos? Disagreement, Market Failure, and Securities Regulation, 81 VA. L. REV. 611, 646-50 (1995). For an argument that the notion of fundamental value is "fantastic," see Murray Glickman, The Concept of Information, Intractable Uncertainty, and the Current State of the "Efficient Markets" Theory: A Post Keynesian View, $16 \mathrm{~J}$. POST KEYNESIAN ECON. 325, 332-33 (1994).

155. Stout, supra note 154 , at 648 . 
that, at least in some circumstances, stock prices do not accurately reflect fundamental values. ${ }^{156}$

Attempts to identify and explain deviations from fundamental values suffer from the fact that, in most instances, fundamental values are unknowable. ${ }^{157}$ Generally, the most that one can do is to test actual stock prices against predicted stock prices, but the failure of actual and predicted prices to coincide does not necessarily indicate that stock markets are inefficient; it could indicate that the model used to predict prices is inaccurate. ${ }^{158}$

The most popular stock price predictor over the past thirty years has been the Capital Asset Pricing Model (CAPM), ${ }^{159}$ which attempts to predict stock prices based on the level of systematic or nondiversifiable risk. ${ }^{160}$ Recent tests of the accuracy of CAPM have been disappointing. Fama and French concluded, for example, that "our tests do not support the most basic prediction of the [CAPM], that average stock returns are positively related to the market

156. See, e.g., Werner F.M. DeBondt \& Richard Thaler, Does the Stock Market Overreact?, 40 J. FIN. 793, 795 (1985) (mean reversion of prices); Werner F.M. DeBondt \& Richard Thaler, Further Evidence on Investor Overreaction and Stock Market Seasonality, 42 J. FIN. 557, 579 (1987) (same); David N. DeJong \& Charles H. Whiteman, The Temporal Stability of Dividends and Stock Prices: Evidence from the Likelihood Function, 81 AM. ECON. REv. 600, 614-15 (1991) (stock price volatility not explained by news about future dividends); J. Bradford DeLong \& Andrei Shleifer, The Stock Market Bubble of 1929: Evidence from Closed-end Mutual Funds, 51 J. ECON. HIST. 675, 675-79 (1991) (discounts in prices of closed-end mutual funds); Burton G. Malkiel, The Valuation of Closed-End Investment-Company Shares, 32 J. FIN. 847, 857-58 (1977) (same); R. Hal Mason \& Maurice B. Goudzwaard, Performance of Conglomerate Firms: A Portfolio Approach, 31 J. FIN. 39, 46-47 (1976) (conglomerate discount); Kenneth D. West, Bubbles, Fads and Stock Price Volatility Tests: A Partial Evaluation, 43 J. FIN. 639, 639 (1988) ("[S]tock prices are more volatile than can be explained by a standard constant-expectedreturn model."); see also SIDNEY COTTLE ET AL., GRAHAM AND DODD's SECURITY ANALYSIS 43 (5th ed. 1988) ("In general, investment practitioners now concede the existence of an intrinsic value that differs from price.").

157. RONALD J. GILSON \& BERNARD S. BLACK, THE LAW AND FINANCE OF CORPORATE ACQUISITIONS 137 (2d ed. 1995) ("[W]e don't know what the 'right' price for an asset is. Thus we can't test ECMH directly, by comparing the actual price to a theoretically correct price.").

158. Id. at 116 ("[A]11 asset pricing models offer a normative theory of how assets should be priced. If assets are not priced as the theory predicts, that could mean the theory is wrong. But it could also mean that assets are mispriced.").

159. The development of CAPM is generally credited to William F. Sharpe, Capital Asset Prices: A Theory of Market Equilibrium Under Conditions of Risk, 19 J. FIN. 425, 436-42 (1964); John Lintner, Security Prices, Risk, and Maximal Gains from Diversification, 20 J. FIN. 587, 597-601 (1965); and Jan Mossin, Equilibrium in a Capital Asset Market, 34 ECONOMETRICA 768, 769-83 (1966).

160. For an introduction to CAPM, see BREALEY \& MYERS, supra note 146, at 155-73; RosS ET AL., supra note 146, at 271-307. 
[betas]."161 One conclusion that might be drawn from the failure of CAPM to withstand empirical testing is that the model is too simple to predict stock prices accurately; ${ }^{162}$ another is that securities are not priced rationally.

This latter attack on securities pricing has been launched in recent years by proponents of theories of "noise trading."163 "Noise trading" occurs when investors trade for reasons unrelated to information about payoffs of the investment. ${ }^{164}$ The most prominent view of noise trading suggests that investors who trade based on noise are irrational. In the words of Fischer Black, "People who trade on noise are willing to trade even though from an objective point of view they would be better off not trading. Perhaps they think the noise they are trading on is information. Or perhaps they just like to trade."165

Although economists have long recognized the existence of such irrational trading, the importance of irrational trading to price formation usually has been discounted on the ground that investors trading based on information will drive prices toward fundamental values. DeLong et al. summarize the case against the importance of irrational trading as follows:

161. Eugene F. Fama \& Kenneth R. French, The Cross-Section of Expected Stock Returns, 47 J. FIN. 427, 428 (1992). But see Fischer Black, Beta and Return, J. PORTFOLIO MGMT., Fall 1993, at 8, 9 (arguing that beta is "alive and well" after Fama and French); Dongcheol Kim, The Errors in the Variables Problem in the Cross-Section of Expected Stock Returns, 50 J. FIN 1605, 1605 (1995) (arguing that Fama and French's findings are subject to the errors-in-variables problem that could underestimate the predictive value of beta). "Beta" is a measurement of market risk that indicates how sensitive a security's price is to movements of the broader market. See BREALEY \& MYERS, supra note 146, at 143-45; ROSS ET AL., supra note 146, at 301-03.

162. Responding to this need for more complex predictors of stock prices, economists have developed other models, the most prominent of which is the Arbitrage Pricing Theory (APT), developed by Stephen Ross. See Stephen A. Ross, The Arbitrage Theory of Capital Asset Pricing, 13 J. ECON. THEORY 341, 355-56 (1976). APT is based on the notion that arbitrage in the financial markets will eliminate price differences in comparable-risk securities.

163. See Black, supra note 148, at 529-30; J. Bradford De Long et al., Noise Trader Risk in Financial Markets, 98 J. POL. ECON. 703, 705 (1990); Andrei Shleifer \& Lawrence H. Summers, The Noise Trader Approach to Finance, 4 J. ECON. PERSP. 19, 30-31 (Spring 1990).

164. Black, supra note 148, at 529, 531 ("In my basic model of financial markets, noise is contrasted with information" and "[n]oise trading is trading on noise as if it were information"); Sanford J. Grossman, Dynamic Asset Allocation and the Informational Efficiency of Markets, 50 J. FIN. 773, 774 (1995) ("I first used the concept of noise to describe the extent to which prices move for stochastic reasons unrelated to payoffs.").

165. Black, supra note 148, at 531; cf. ROBERT J. SHILLER, MARKET VOLATILITY 57-60 (1989) (arguing that investors trade because they enjoy trading). 
[I]rrational investors are met in the market by arbitrageurs who trade against them and in the process drive prices closer to fundamental values. Moreover, in the course of such trading, those whose judgments of asset values are sufficiently mistaken to affect prices lose money to arbitrageurs and so eventually disappear from the market.... Noise traders thus cannot affect prices too much and, even if they can, will not do so for long. ${ }^{166}$

Recent proponents of the importance of noise trading in price formation contend that trading by rational investors (i.e., investors trading on information or "arbitrageurs") is more limited than once thought and thus less effective at driving prices towards fundamental values. ${ }^{167}$ In addition, behavioral studies suggest that investor irrationality may be more common and systematic than "the random sort that classical theory holds will cancel out."168

Sanford Grossman has developed another view of "noise" in stock prices that differs substantively from the view that noise traders are irrational, a position that Grossman criticizes as a "derogatory view [that] is not a helpful description of the noninformational role of markets."169 Grossman contends that noise in stock prices is created by allocational price changes (i.e., price changes caused for reasons unrelated to new information about asset payoffs), such as "cross-

166. DeLong et al., supra note 163, at 704 (citing Milton Friedman, The Case for Flexible Exchange Rates, in ESSAYS IN POSITIVE ECONOMICS 157 (1953), and Eugene F. Fama, The Behavior of Stock-Market Prices, 38 J. Bus. 34 (1965), as "forcefully" making the argument against the importance of noise trading).

167. Id. at 705-06.

168. Langevoort, supra note 152, at 862 . After discussing behavioral studies suggesting "the tendency of persons to make probabalistic decisions based on salient or easily recalled information, rather than on base-rates and other more complete data sets," id. at 859, "the tendency of people to be overconfident in their predictive abilities," $i d$., and "the tendency to value that which is possessed more highly than that which is not: to value out-of-pocket losses more than opportunity costs," id. at 859-60, Langevoort explains the sorting function under classical theory as follows:

Explanations for why the market operates efficiently are frequently based on the belief that even "uninformed" decision-making by market participants is improved by the consensus effect. Mistakes, biases, and excessive optimism or pessimism are removed from the price-setting process because the random, uninformed biases of individuals in the market will cancel each other out, resulting in a market that on average exhibits a capacity for greater predictive accuracy than the forecasts for any individual trader. For this effect to operate with substantial cleansing power, however, investors must operate in a largely independent fashion with unsystematic biases. On the other hand, if their errors take on a systematic or contagious character, this analysis weakens.

Id. at 862 (footnote omitted).

169. Grossman, supra note 164 , at 774 . 
sectional changes in wealth, risk preferences, liquidity needs, unanticipated investment opportunities, and all factors that do not directly relate to the payoffs on the securities being traded."170

One implication of all noise trading theories is that capital markets are not fundamental-value efficient. ${ }^{171}$ But even if stock prices deviate from fundamental values, theories of noise trading do not predict whether prices are too high or too low in relation to fundamental values. Some economists argue, however, that stock prices may be systematically wrong about fundamental values, thus diminishing the ability of capital markets to play a monitoring role in the corporate governance system. ${ }^{172}$ Paul Milgrom and John Roberts, for example, build from the premise that managers ideally should strive to maximize a firm's fundamental value, which they define as the sum of the current and future earnings of the firm. ${ }^{173}$ From this premise, they reason that capital markets provide proper incentives to managers only if "maximizing the fundamental value of the firm to its shareholders is equivalent to maximizing the value of the firm's shares."174 Milgrom and Roberts contend that this congruence of fundamental value and stock price occurs only if the strong form of the ECMH is valid because "even if markets use all public information perfectly to forecast efficiently [i.e., even if the semi-strong form of the ECMH is valid], that information may still reflect more fully efforts that boost short-term earnings than ones that increase long-term values."175 In other words, either form of the ECMH other than the strong form implies that some information

170. Id. at 775. Grossman provides two well-known illustrations in support of his theory: "the fall in global equity prices associated with the $1987 \mathrm{crash}$, and the rise in real interest rates in Germany following German unification in 1990." Id. The first can be explained by "a significant fraction of investors becoming more risk averse about equities, thus seeking to reduce their equity holdings" by lowering prices. Id. at 776. The second can be explained by the "massive capital expenditure needed to rebuild East Germany," resulting in higher interest rates to induce the flow of capital to Germany. Id.

171. Black, supra note 148 , at 532.

172. PAUL MILGROM \& JOHN ROBERTS, ECONOMICS, ORGANIZATION AND MANAGEMENT 471 (1992); Robert W. Rosenthal \& Ruqu Wang, An Explanation of Inefficiency in Markets and a Justification for Buy-and-Hold Strategies, 26 CANADIAN J. ECON. 609, 609-12 (1993) (market prices systematically understate fundamental values because owners are occasionally forced to sell to raise cash for exogenous reasons).

173. MILGROM \& ROBERTS, supra note 172 , at 471.

174. Id. at 477; see also Ayres, supra note 147, at $985-86$ (maximizing underlying profits of a corporation and maximizing the present value of a corporation's stock "are only identical if a corporation's stock is traded on an exchange that is both fundamentally efficient and strong-form informationally efficient").

175. MILGROM \& ROBERTS, supra note 172 , at 477. 
relevant to the fundamental value of a company will be excluded in establishing the company's stock price, and the information most likely to be excluded is information relating to the long-term value of the company. To the extent that such information is excluded, the stock price will send a deficient signal to the managers of the company. The ability of capital markets to play a monitoring role in the corporate governance system, therefore, depends on the validity of strong-form efficiency-a highly improbable proposition.

Milgrom and Roberts join many others who contend that stock prices overemphasize short-term value, ${ }^{176}$ but their claim that capital markets are shortsighted creates a puzzle: If markets systematically undervalue the long-term prospects of companies because markets lack adequate information regarding the companies, why don't managers who are creating long-term value simply disclose more about what they are doing? One explanation may be that managers will not disclose information about the future prospects of their company if that information will benefit competitors. ${ }^{177}$ Murray Glickman recently argued from a post-Keynesian perspective that virtually all shareholders focus on short-term results rather than longterm expectations because they care about liquidity; in his words, "their specific motivation for holding financial rather than real assets [is] to free themselves from total dependence on" long-term performance. ${ }^{178}$ Milgrom and Roberts suggest another answer. They contend that investors normally will find gathering and evaluating information easier if it involves short-term performance rather than long-term potential of a company. The result is that stock prices will become more sensitive to indicators of short-term performance than to indicators of long-term value, and executives will emphasize "activities that boost short-term performance compared to those

176. For examples in the legal literature, see LoUIS LOWENSTEIN, WHAT'S WRONG WITH WALL STREET: SHORT-TERM GAIN AND THE ABSENTEE SHAREHOLDER 205-18 (1988); Thomas Lee Hazen, The Short-Term/Long-Term Dichotomy and Investment Theory: Implications for Securities Market Regulation and for Corporate Law, 70 N.C. L. REV. 137, 142-43 (1991); Lipton \& Rosenblum, supra note 135, at 188.

177. Cf. EASTERBROOK \& FISCHEL, supra note 90, at 26:

Managers seek to disclose all the information that is privately optimal to investors, because that will induce investors to part with more money for their shares. But some disclosures may be beneficial to other firms, too, and unless legal rules set up a requirement of reciprocal disclosure none of the firms may find it beneficial to disclose information that is valuable to investors.

178. Glickman, supra note 154 , at $332-33$. 
whose benefits will be hidden from investors for a long period of time." $" 179$

A final attack against fundamental-value efficiency was discussed recently by Lynn Stout, who argued that a model of stock pricing that takes account of the fact that investors have heterogeneous expectations about the future prospects of a company "preserves the assumption of investor rationality while nevertheless explaining how informationally efficient stock markets can produce prices that fail to reflect best estimates of fundamental value." 180

The foregoing discussion suggests that the price of Kmart's stock may not have reflected Kmart's fundamental value for several reasons: (1) Kmart stock may be subject to one of the many wellaccepted deviations from fundamental value (e.g., the conglomerate discount); (2) Kmart's stock may have been wrongly priced because investors were irrational or because of allocational price changes; (3) the capital markets might have undervalued Antonini's efforts to improve Kmart's long-term performance as Milgrom and Roberts' argument suggests; or (4) investors may simply have had heterogeneous expectations for Kmart's future prospects. If Kmart's stock were mispriced in any of these ways, the implications for corporate governance would be significant. ${ }^{181}$ Even if Kmart stock were accurately priced according to Kmart's fundamental value, those prices may not have reflected Antonini's performance. As Peter Drucker suggested, stock prices reflect information on many factors other than managerial performance. ${ }^{182}$

179. MILGROM \& ROBERTS, supra note 172 , at 471 . They add:

Worse, this problem can be self-reinforcing. Short-term investors are inclined to gather the information that is most valuable for forecasting short-term price changes. Realizing that short-term performance is the prime determinant of prices, these investors will then be inclined to devote even more resources to getting early and accurate information about earnings, neglecting the difficult, Id. costly, and time-consuming task of assessing long-term prospects.

180. Stout, supra note 154 , at $651-52$. This view of capital markets closely resembles Glickman's post-Keynesian approach. See Glickman, supra note 154, at 336 . For discussions of heterogeneous expectations in the finance literature, see Robert Jarrow, Heterogeneous Expectations, Restrictions on Short Sales, and Equilibrium Asset Prices, 35 J. FIN. 1105 (1980); Edward M. Miller, Risk, Uncertainty, and Divergence of Opinion, 32 J. FIN. 1151 (1977); Robert E. Verrecchia, Information Acquisition in a Noisy Rational Expectations Economy, 50 ECONOMETRICA 1415 (1982).

181. See infra Part IV.A for the implications of markets that are not fundamental-value efficient.

182. See supra note 144 and accompanying text. 
With respect to Kmart's corporate governance problem, therefore, it is possible that the capital markets were sending bad signals to Antonini, to Kmart's board of directors, and to investors regarding Antonini's performance. Even if the stock price were appropriately valued, however, the capital markets qua corporate governance mechanism cannot solve the adverse selection problem. Capital markets, standing alone, cannot correct for incompetence. To the extent that they accurately reflect performance, they provide incentives to improve performance, but an executive who already is exerting full effort will be unable to respond to these incentives. The most that capital markets can do to solve the adverse selection problem, therefore, is: (1) to send accurate signals to another corporate governance mechanism-either the market for corporate control or the board of directors-that the manager is incompetent and needs to be replaced; and (2) to prevent the manager from accessing additional capital, thus making the company less competitive and ultimately (if the market for corporate control or the board of directors does not intervene) driving the company out of business.

\section{Market for Corporate Control}

In his article on the market for corporate control, Henry Manne introduced the study of takeovers as a corporate governance mechanism. ${ }^{183}$ Manne noted that a "fundamental premise underlying the market for corporate control is the existence of a high positive correlation between corporate managerial efficiency and the market price of the shares of that company."184 In other words, this constraint on managerial behavior also depends on the ability of capital markets to reflect accurately the quality of managerial performance. Assuming that such a correlation exists, the theory underlying the market for corporate control posits that managers who do not maximize the value of a firm are susceptible to takeover by third parties who may gain by purchasing the firm's shares at a price above the market price but below the value of the firm if it were well managed. ${ }^{185}$

183. See Henry G. Manne, Mergers and the Market for Corporate Control, 73 J. Pol. ECON. 110 (1965).

184. Id. at 112 .

185. Subsequent research suggests that at least some takeovers are indeed motivated by managerial inefficiency. Michael C. Jensen, Takeovers: Their Causes and Consequences, J. ECON. PERSP., Winter 1988, at 21, 27-28. Ian Ayres and Peter Cramton note that most theories of the market for corporate control address managerial incompetence, not managerial abuse. Ayres \& Cramton, supra note 15, at 1052. 
Since Manne wrote, there have been many developments in the market for corporate control. The 1980s saw the rise of hostile takeovers and an outpouring of scholarship both in support of and in opposition to Manne's thesis. ${ }^{186}$ The early 1990 s witnessed a precipitous decline in the number of hostile takeover bids, resulting from the confluence of a number of events, including changes in law $^{187}$ and in the availability of money to finance takeovers following the collapse of the junk bond market. ${ }^{188}$

Although many commentators still praise the role of the market for corporate control in the corporate governance system, ${ }^{189}$ others are not so sanguine. ${ }^{190}$ During the early 1990s, when takeovers all but disappeared from the corporate radar screen, John Pound declared: "In [the] view [of economists], takeovers were an efficient means of corporate governance because it was inherent in the American financial system that shareholders would be passive and directors uninvolved. ... Seldom has an entire philosophy proved so wrong in so short a time."191 Since Pound's bold report of the death of the market for corporate control, mergers and acquisitions have

186. For an excellent summary of the debate, see Roberta Romano, $A$ Guide to Takeovers: Theory, Evidence and Regulation, 9 YALE J. ON REG. 119 (1992).

187. Courts have been extremely active in evaluating new takeover developments in the 1980s and 1990s. In CTS Corp. v. Dynamics Corp. of America, 481 U.S. 69, 94 (1987), the Supreme Court approved a state antitakeover statute for the first time, thus validating the so-called "second generation" antitakeover statutes adopted in the wake of Edgar v. MITE Corp., 457 U.S. 624 (1982). Many of the most important changes occurred in the Delaware courts. See, e.g., Paramount Communications v. QVC Network, 637 A.2d 34 (Del. 1994) (invalidating restrictive provisions in merger agreement); Paramount Communications v. Time Inc., 571 A.2d 1140, 1151 (Del. 1989) (approving the "just say no" defense); Revlon v. MacAndrews \& Forbes Holdings, 506 A.2d 173 (Del. 1986) (requiring the board to conduct a fair auction once the company is "in play"); Moran v. Household Int'l, 500 A.2d 1346 (Del. 1985) (upholding poison pill); Unocal Corp. v. Mesa Petroleum Co., 493 A.2d 946 (Del. 1985) (subjecting defensive measures to enhanced judicial scrutiny). For a recent discussion of the development of Delaware jurisprudence, see Paul L. Regan, The Unimportance of Being Earnest: Paramount Rewrites the Rules for Enhanced Scrutiny in Corporate Takeovers, 46 HASTINGS L.J. 125 (1994).

188. See Stephen M. Bainbridge, Redirecting State Takeover Laws at Proxy Contests, 1992 WIS. L. REV. 1071, 1085-86.

189. See, e.g., EASTERBROOK \& FISCHEL, supra note 90, at 171 ; Jonathan R. Macey \& Geoffrey P. Miller, Corporate Governance and Commercial Banking: A Comparative Examination of Germany, Japan and the United States, 48 STAN. L. REV. 73, 101-105 (1995); Romano, supra note 186, at 129-33.

190. See, e.g., Amar Bhide, Efficient Markets, Deficient Governance, HARV. Bus. REV., Nov.-Dec. 1994, at 128, 136-37; Melvin A. Eisenberg, The Structure of Corporation Law, 89 COLUM. L. REV. 1461, 1497 (1989); Lipton \& Rosenblum, supra note 135, at 198-201.

191. John Pound, The Rise of the Political Model of Corporate Governance and Corporate Control, 68 N.Y.U. L. REV. 1003, 1005 (1993). 
come back with a flourish, setting new records in 1994 and again in 1995. ${ }^{192}$ Admittedly, this activity is qualitatively different than the hostile takeover activity of the $1980 \mathrm{~s},{ }^{193}$ and this difference may affect the ability of the market for corporate control to correct managerial incompetence because friendly mergers tend not to be motivated by managerial incompetence and often do not result in the replacement of managers. ${ }^{194}$ Moreover, the inconsistency of the takeover market may be cause for concern, depending on the role the market for corporate control is to play in the corporate governance system. According to Henry Butler, "it is the threat of takeover, not the actual occurrence of a takeover, which serves to align managers' interests with shareholders' interests."195 But if there are long periods during which, for whatever reason, the threat of takeover is diminished, the corporate governance role of the market for corporate control will be correspondingly diminished. Furthermore, if the market for corporate control is expected to correct for incompetent management, threats are not enough. As noted above, no incentive-no matter how great-can cause a manager to perform beyond his or her ability. The only corrective for incompetence is replacement of the incompetent manager, and to accomplish this, the market for corporate control must do more than threaten. It must act.

Kmart has so far been spared from takeover bids. For a short time, rumors circulated that Dayton-Hudson, the parent company of Target, was interested in acquiring $\mathrm{Kmart},{ }^{196}$ but those rumors were

192. Steven Lipin, Let's Do It: Disney to Diaper Makers Push Mergers and Acquisitions to Record High, WALL ST. J., Jan. 2, 1996, at R8 (citing figures from Securities Data Co.).

193. See, e.g., Steven Lipin, Let's Get Together: In Today's Mergers, One Plus One Must Equal More Than Two, WALL ST. J., Aug. 1, 1995, at A1 ("[U]nlike the manic merger action of the 1980 s, the combinations being assembled these days aren't about instant gratification and the milking of corporate coffers. They're about long-term growth and competition."); Richard Thomson, Corporate US Junks Excesses of Eighties Merger Mania, THE TIMES (London), Aug. 7, 1995, at 35 (observing that "although the sums are huge, the atmosphere is not the same as that of the 1980s mania" and noting that in 1988 there were 66 hostile bids, but in 1995 there have been only 19 hostile bids). But see id. (noting that the number of hostile takeovers is rising); Steven Lipin, Big Corporations Making Knockout Bids Take the Fight out of Friendly Rescuers, WALL ST. J., Nov. 8, 1995, at $\mathrm{C1}$ (discussing a "boom in mergers and an increasing number of hostile bids").

194. See Kenneth J. Martin \& John J. McConnell, Corporate Performance, Corporate Takeovers, and Managerial Turnover, 46 J. FIN. 671 (1991).

195. Butler, supra note 143, at 112.

196. Christina Duff \& Gregory A. Patterson, Kmart Insiders Are Worrying That Retailer May Be Dayton Hudson Takeover Candidate, WALL ST. J., Jan. 27, 1995, at C2. 
later dismissed as "pie in the sky."197 Institutional investors attempted to make Kmart a more appealing target by supporting a measure at the 1990 Annual Meeting advocating the repeal of Kmart's poison pill. ${ }^{198}$ The board of directors ultimately acceded to the shareholder pressure, phasing out the poison pill in $1995 .^{199}$

The absence of a takeover bid for Kmart prior to Antonini's ouster may simply be a testament to the effectiveness of Kmart's poison pill. Alternatively, the absence of a bid could be the result of the general lull in takeover activity during the early 1990s. Or it may be that potential acquirors did not sense the "flagrant incompetence or abuse" among management that would allow them to make a profit from Kmart. Finally, it may simply be a question of timing and Kmart may eventually be acquired. Whatever the explanation, it is clear that if the problem with Kmart was managerial incompetence, the market for corporate control was at best slow to act and at worst ineffective in that it did not cause the replacement of Antonini.

\section{Product Markets}

Ronald Gilson and Mark Roe have asserted, "The most elegant monitoring mechanism is intense product market competition."200 Jeffrey Gordon contends that a competitive product market "will discipline managers more vigorously than any board could."201 In another forum, Gilson elaborated on the basic concept:

A competitive market for the good or service the corporation produces disciplines management long before the market for corporate control or any other element of the corporate governance system can operate. In this sense, much of corporate governance operates only because product markets are not perfectly competitive; takeovers, for example, were not an important factor in industries with competitive product markets because the discipline of such

197. Richard Halverson, Kmart Dividend in Peril; Undervalued Retailer a Takeover Candidate, DisCOUNT STORE NEWs, Mar. 20, 1995, at 29.

198. See supra note 108.

199. See supra note 108.

200. Ronald J. Gilson \& Mark J. Roe, Understanding the Japanese Keiretsu: Overlaps Between Corporate Governance and Industrial Organization, 102 YALE L.J. 871, 891-95 (1993).

201. Jeffrey N. Gordon, Institutions as Relational Investors: $A$ New Look at Cumulative Voting, 94 ColuM. L. REV. 124, 124 n.1 (1994). 
markets operates much more quickly than the market for corporate control. ${ }^{202}$

Although product markets may act quickly in sending signals regarding a firm's lack of competitiveness, the real disciplining effect of product markets may not be felt for years. Indeed, Michael Jensen has commented that "product ... markets are slow to act as a control force, [and] when product . . . disciplines take effect it can be too late to save much of the enterprise."203 Jensen's observation suggests that the proper role of product markets in the corporate governance system may be to provide incentives for managers who hope to survive over the long term and to inflict the ultimate punishment-"exit" or bankruptcy-as a last resort for companies that fail to heed the signals.

With respect to Kmart's corporate governance problem, the product markets sent strong signals that Kmart was being outmaneuvered by Wal-Mart. ${ }^{204}$ But it is not clear that Antonini was

202. Gilson, supra note 22, at 655 ; see also Butler, supra note 143 , at 114 (describing the role of product market competition in corporate governance); Ronald J. Gilson, Evaluating Dual Class Common Stock: The Relevance of Substitutes, 73 VA. L. REV. 807, 828-29 n.57 (1987) (stating that "in a world where the product market operates to align the interests of management and shareholders, little role is left for the market for corporate control"); Mark J. Roe, Some Differences in Corporate Structure in Germany, Japan, and the United States, 102 YALE L.J. 1927, 1994-95 (1993) (explaining the impact of a competitive market on an international scale). For a formal examination of the role of product competition in reducing managerial slack, see Oliver D. Hart, The Market Mechanism as an Incentive Scheme, 14 BELL J. ECON. 366 (1983).

203. Michael C. Jensen, The Modern Industrial Revolution, Exit, and the Failure of Internal Control Systems, 48 J. FIN. 831, 850 (1993); see also Eisenberg, supra note 190, at 1489 (arguing that an "imperfectly competitive market will not quickly convert unfair selfdealing or inefficiency into insolvency" because "[m]ost publicly held corporations have sufficient resources and market power to absorb substantial losses").

204. In a recent report on American industry, Forbes listed Kmart as twenty-first of 25 "Drug and discount" retailers for which numbers were available in terms of average return on equity over the past five years. Zina Moukheiber, Retailing, FORBES, Jan. 1, 1996, at 156, 157-58. The following are selected numbers, taken from the Forbes article, comparing Kmart, Wal-Mart, and median numbers for drug and discount retailers:

\begin{tabular}{||c|c|c|c||}
\hline & Industry Median & Kmart & Wal-Mart \\
\hline \hline $\begin{array}{c}\text { Return on Equity } \\
\text { (5 years) }\end{array}$ & $12.9 \%$ & $4.2 \%$ & $27.3 \%$ \\
\hline $\begin{array}{c}\text { Return on Capital } \\
\text { (12 months) }\end{array}$ & $8.7 \%$ & $2.5 \%$ & $14.0 \%$ \\
\hline $\begin{array}{c}\text { Sales Growth } \\
\text { (5 years) }\end{array}$ & $7.5 \%$ & $2.8 \%$ & $26.4 \%$ \\
\hline
\end{tabular}


to blame. Although he was at the controls for over seven years, he inherited massive problems at Kmart. This suggests a possible shortcoming of product markets as mechanisms for evaluating managerial performance that is largely overlooked in the corporate governance literature: namely, that product markets punish past mistakes until they are corrected and sometimes long thereafter. When poor management performance issues the call to arms, product markets lumber to the front, often not engaging in battle for some time. Certainly the threat to long-term management tenure is present, but product markets may punish a manager for assuming leadership of a company with many problems. ${ }^{205}$

Another shortcoming of product markets as a corporate governance mechanism is that managers can circumvent their disciplining effect through diversification. When managers acquire lines of business that have different business cycles, the managers are (intentionally or unintentionally) insulating themselves from product market discipline. ${ }^{206}$ Empirical evidence on the effect of diver-

205. This can be seen more clearly in the case of Antonini's successor, Floyd Hall, as Kmart is the subject of rumors of impending bankruptcy. See infra note 317 and accompanying text.

206. For the suggestion that managers sometimes pursue acquisitions for personal gains, see Yakov Amihud \& Baruch Lev, Risk Reduction as a Managerial Motive for Conglomerate Mergers, 12 BELL J. ECON. 605, 606 (1981):

Quite often, a firm's failure to achieve predetermined performance targets, or in the extreme case the occurrence of bankruptcy, will result in the managers' losing their current employment and seriously hurting their future employment and earnings potential. Such "employment risk" cannot be effectively diversified by managers in their personal portfolios, since unlike many other sources of income such as stocks, human capital cannot be traded in competitive markets. Riskaverse managers can therefore be expected to diversify this employment risk by other means, such as engaging their firms in conglomerate mergers, which generally stabilize the firm's income stream and may even be used to avoid the disastrous effects bankruptcy has on managers.

See also Randall Morck et al., Do Managerial Objectives Drive Bad Acquisitions?, $45 \mathrm{~J}$. FIN. 31, 31-32 (1990) ("Some investments are particularly attractive from the ... perspective [of personal benefits to managers]: they contribute to long term growth of the firm, enable the manager to diversify the risk on his human capital, or improve his job security."). Although this Article concentrates on the effect of diversification on product market discipline, Cynthia Montgomery has identified three reasons why self-interested managers might engage in excessive diversification: (1) "the pleasures of empire building"; (2) to "direct a firm's diversification in a way that increases the firm's demands for his or her particular skills" ("managerial entrenchment"); and (3) to reduce "total firm risk, thus improving their personal positions while not benefitting the firm's stockholders." Cynthia A. Montgomery, Corporate Diversification, J. ECON. PERSP., Summer 1994, at 163, 166. Montgomery also suggests two profit maximization rationales for the diversification: (1) firms may obtain market power through diversification by reducing the effects of 
sification (and the resulting reduction in product market discipline) on firm performance is difficult to interpret, primarily because defining diversification and measuring the returns from diversification are extremely difficult undertakings. Nevertheless, as a general rule, "firms with higher levels of diversification are less profitable than firms with lower levels of diversification."207 Diversification, therefore, usually does not benefit shareholders, who are wellequipped to diversify themselves. ${ }^{208}$

Although Antonini may have been pursuing a diversification strategy for personal gains, this seems unlikely. Kmart remained primarily a discount retailer, even after diversification, ${ }^{209}$ and observers of the retail industry generally praised his diversification efforts. ${ }^{210}$ Indeed, one commentator recently suggested that Kmart should have considered selling its discount stores to concentrate on specialty retailing. ${ }^{211}$ The specialty retail strategy, therefore, does not appear to have been designed to shield Antonini from product market discipline, even if it may have had that effect. ${ }^{212}$

competition through cross subsidization, mutual forbearance among competitors who meet in multiple markets, or reciprocal buying among large diversified firms; and (2) firms may use diversification to employ underused resources more profitably (the "resource view"). Id. at 165-68. Of all rationales for diversification (including agency costs), only the resource view is efficiency enhancing. Id. at 164.

207. Montgomery, supra note 206, at 172; see also Mason \& Goudzwaard, supra note 156 , at 39 ("[R]andomly selected portfolios offered superior earnings performance and shareholder returns than did the conglomerates in our sample."); Ronald W. Melicher \& David F. Rush, The Performance of Conglomerate Firms: Recent Risk and Return Experience, 28 J. FIN. 381, 387 (1973) ("[C]onglomerate diversification may be an effective means for obtaining 'defensive diversification,' but it does not seem to be an effective vehicle for obtaining superior or outstanding performance.").

208. On the effects of diversification on shareholder value, see Michael C. Jensen, Agency Costs of Free Cash Flow, Corporate Finance, and Takeovers, 76 AM. ECON. REV. 323,328 (1986).

209. In 1993 approximately $82 \%$ of its revenues were generated by the discount stores. 1993 ANNUAL REPORT, supra note 43, at H6 (showing "general merchandise" sales of $\$ 28.039$ billion and "specialty retail groups" sales of $\$ 6.117$ billion).

210. See, e.g., Laura Liebeck, Kmart Power Centers Evolve Into Strong Contenders, DisCOUNT STORE NEWS, Dec. 6, 1993, at 92 (calling Kmart Power Centers "one of the most innovative retail real estate strategies of the past decade" and predicting "discount store/category-killer combination centers will spring up throughout the nation"); James A. McConville, Kmart "Giving OfficeMax Clout": Management of Superstore Chain to Stay Intact, Company to Remain Autonomous, HFD-WKLY. HOME FURNISHINGS NEWSPAPER, Oct. 28, 1991, at 102, 102 (quoting industry analyst Kurt Barnard as saying, with respect to the acquisition of OfficeMax, "It is a sound and a very sensible move for Kmart to make.").

211. Lisanti, supra note 141 , at 15.

212. In this regard, it is interesting to note that only after $\mathrm{Kmart}$ disposed of most of its specialty retailers have rumors of Kmart's impending bankruptcy begun to circulate. 


\section{Managerial Labor Markets}

Eugene Fama first argued the importance of managerial labor markets in aligning the interests of managers and shareholders, asserting that "the primary disciplining of managers comes through managerial labor markets, both within and outside of the firm.".213 Monitoring within the firm consists of managers monitoring each other, both higher and lower in the hierarchy, ${ }^{214}$ and monitoring outside the firm consists of managers attempting to move from one company to another and being rewarded or penalized based on their past performance. ${ }^{215}$

Many observers of Kmart credit stiff competition among discount retailers with causing Antonini's fall, suggesting that Kmart's limited diversification was insufficient to insulate Antonini forever. See, e.g., Duff \& Ortega, supra note 1, at A1 (arguing that Antonini's forced resignation was an "official verdict" in the battle between Kmart and Wal-Mart); John McManus, Antonini knew what Kmart couldn't be but failed to define what it would be, BRANDWEEK, Mar. 27, 1995, at 16 (praising Antonini's ouster on grounds that "the playing field [between Kmart and Wal-Mart] clearly needs leveling" by bringing in a new manager to Kmart).

213. Eugene F. Fama, Agency Problems and the Theory of the Firm, 88 J. POL. ECON. 288, 295 (1980); see also Fischel, supra note 27, at 1263 ("[M]anagers have strong incentives to maximize the market value of their own services within the firm and to other possible employers.").

214. Fama, supra note 213, at 293:

There is ... much internal monitoring of managers by managers themselves. Part of the talent of a manager is his ability to elicit and measure the productivity of lower managers, so there is a natural process of monitoring from higher to lower levels of management. Less well appreciated, however, is the monitoring that takes place from bottom to top. Lower managers perceive that they can gain by stepping over shirking or less competent managers above them. Moreover, in the team or nexus of contracts view of the firm, each manager is concerned with the performance of managers above and below him since his marginal product is likely to be a positive function of theirs. Finally, although higher managers are affected more than lower managers, all managers realize that the managerial labor market uses the performance of the firm to determine each manager's outside opportunity wage. In short, each manager has a stake in the performance of the managers above and below him and, as a consequence, undertakes some amount of monitoring in both directions.

215. See id. at 292:

The outside managerial labor market exerts many direct pressures on the firm to sort and compensate managers according to performance. One form of pressure comes from the fact that an ongoing firm is always in the market for new managers. Potential new managers are concerned with the mechanics by which their performance will be judged, and they seek information about the responsiveness of the system in rewarding performance. Moreover, given a competitive managerial labor market, when the firm's reward system is not responsive to performance the firm loses managers, and the best are the first to leave. 
Even if managerial labor markets operate as Fama described, ${ }^{216}$ the efficacy of managerial monitoring within Kmart is doubtful in Antonini's case, where there was no monitoring by managers higher than Antonini because he held the top three posts at Kmart, and where any attempts at monitoring from below probably would have been stifled. ${ }^{217}$ In addition, as CEO of Kmart, Antonini may have been less responsive to external labor markets than many managers because chief executive officers tend to retain their positions until retirement. ${ }^{218}$ Admittedly, Antonini may have been different because he was only fifty-three years old when he resigned and because his severance agreement with Kmart contained an unusual provision requiring him to seek other employment after leaving Kmart. ${ }^{219}$ Still, Antonini spent his entire career working for Kmart and a transition to a new executive position probably would prove difficult. Given his many years of high earnings as an officer of Kmart and his generous severance and retirement package, ${ }^{220}$ it seems unlikely that he would need to seek another position to maintain his standard of living. All of this suggests that even if managerial labor markets sometimes constrain managers (as intuitively they should), they did not work very effectively in Kmart.

With respect to Kmart's corporate governance problem, managerial labor markets are relatively innocuous. All the monitoring in the world will not improve an incompetent manager, and there is no mechanism in the managerial labor markets per se for replacing an incompetent manager. The most one might hope for from the managerial labor markets with respect to solving the adverse selection problem is that they will act as a screen against managers who have proved themselves incompetent in previous positions.

216. For an argument that Fama's description of the managerial labor markets is unrealistic, see FoX, supra note 135, at 143-46.

217. Duff, supra note 38, at A1 ("Colleagues describe Mr. Antonini as 'teflon-coated": Complaints and unsolicited suggestions often slide right off."); Faye Rice, Why K mart Has Stalled, FORTUNE, Oct. 9, 1989, at 79 ("Another reason for K mart's problems: Antonini hates bad news. Says one insider: "There is no one to tell him things are going wrong." ").

218. See Eisenberg, supra note 190, at 1495.

219. Duff et al., supra note 12 , at A3, A10.

220. Antonini will receive his annual base salary of $\$ 923,000$ for two years following his resignation, a bonus of $\$ 597,000$ in 1995 and 1996 , and $\$ 527,064$ a year in annual retirement income after his severance period. Laura Liebeck, Kmart Faces the Future-With Frankness, DiscouNT STORE NEWS, May 1, 1995, at 1. 


\section{Internal Constraints on Managerial Behavior}

When Berle and Means thought about internal constraints on managerial abuse, they thought exclusively about shareholder action. ${ }^{221}$ Boards of directors were not part of the solution to managerial abuse; they were the problem. ${ }^{222}$ Later commentators began to look to the board to fulfill its potential as monitor of corporate officers. ${ }^{223}$ This contributed to the expanded use of outside directors, especially during the 1970s and 1980s. ${ }^{224}$ Under the contractarian view of the corporation, internal constraints play a complementary role to the various external constraints in reducing agency costs. ${ }^{225}$ Internal constraints originate from the board of directors and shareholders, both of which are discussed below.

221. Indeed, the thesis of the book is that the inability of shareholders to act effectively-because of the separation of "ownership" and "control"-requires new legal rules to encourage "a wholly new concept of corporate activity," in which "[n]either the claims of ownership nor those of control can stand against the paramount interests of the community." BERLE \& MEANS, supra note 116, at 312.

222. Berle and Means defined "management" to include both the directors and officers of the corporation. Id. at 196. Although "control" frequently was exercised by a person or group other than the board of directors, $i d$. at 207, and the public "up to now has little quarrel" with self-perpetuating boards like those of U,S. Steel or AT\&T, id. at 218, the crux of Berle and Means' argument was that "we have reached a condition in which the individual interest of the shareholder is definitely made subservient to the will of a controlling group of managers." Id. at 244.

223. See, e.g., MELVIN A. EISENBERG, THE STRUCTURE OF THE CORPORATION 170 (1976)

The major effect of according central importance to [the board's] policymaking function ... has been to divert legal and corporate institutions from implementing a cluster of functions which the board can perform, and which cannot easily be performed by any corporate organ except the board: selecting, monitoring, and removing the members of the chief executive's office.

224. Melvin Eisenberg summarized three studies from the early 1970s showing that "[e]mployee-directors held half or more of the board's seats in 29 percent of the approximately 500 manufacturing corporations in a 1973 Conference Board survey, 49.8 percent of the industrials in the Heidrick \& Struggles sample [1971], and 55.9 percent of the 1970 Fortune 500." Id. at 145. In 1989, Jay Lorsch and Elizabeth MacIver reported that $74 \%$ of all directors in 1989 are outsiders and that by $197983 \%$ of all U.S. companies had a majority of outsider directors. JAY W. LORSCH \& ELIZABETH MACIVER, PAWNS OR POTENTATES: THE REALITY OF AMERICA's CORPORATE BOARDS 17-18 (1989).

225. Fischel, supra note 27 , at 1264. Among other things, internal constraints "deal with last-period, or one-time, divergences when the agent rationally concludes that the benefits of the one-time use of discretion is worth whatever penalties may be forthcoming in the employment market for the agent's services." Butler, supra note 143, at 119. 


\section{Board of Directors}

The board of directors acts as an intermediary between the shareholders and the officers. Although some efforts have been made to diversify board membership to include representatives of nonshareholder constituencies, there seems to be very little real threat to the board's current role as protector of shareholder interests. ${ }^{226}$ In that role, the board is widely viewed as the best hope for corporate governance reform, ${ }^{227}$ even though past performance has been disappointing. ${ }^{228}$ Proposals for reforming the board of directors include electing outside directors to a majority of the board seats, ${ }^{229}$ increasing the role of the board in monitoring management performance, ${ }^{230}$ appointing lead outside directors, ${ }^{231}$ electing professional directors, ${ }^{232}$ allowing representatives of large institutional investors

226. For a detailed argument that shareholders are the only constituency the board should represent, see WILLIAMSON, supra note 133, at 298-325.

227. See, e.g., MONKS \& MINOW, supra note 29, at 36; Ronald J. Gilson \& Reinier Kraakman, Reinventing the Outside Director: An Agenda for Institutional Investors, 43 STAN. L. REV. 863, 905 (1991); Martin Lipton \& Jay W. Lorsch, A Modest Proposal for Improved Corporate Governance, 48 Bus. LAW. 59, 74-76 (1992); James M. Tobin, The Squeeze on Directors-Inside is Out, 49 Bus. LAw. 1707, 1752-57 (1994).

228. See, e.g., Jensen, supra note 203, at 862-63:

The job of the board is to hire, fire, and compensate the CEO, and to provide high-level counsel. Few boards in the past decades have done this job well in the absence of external crises. This is particularly unfortunate given that the very purpose of the internal control mechanism is to provide an early warning system to put the organization back on track before difficulties reach a crisis stage.

229. See, e.g., James D. Cox \& Nis Jul Clausen, The Monitoring Duties of Directors Under the EC Directives: $A$ View From the United States Experience, 2 DUKE J. COMP. \& INT'L L. 29, 31-33 (1992); Lipton \& Lorsch, supra note 227, at 67-69; Donald E. Pease, Outside Directors: Their Importance to the Corporation and Protection From Liability, 12 DEL. J. CORP. L. 25, 31-40 (1987).

230. See, e.g., Lipton \& Lorsch, supra note 227, at 72-74.

231. See, e.g., id. at 70-71.

232. See, e.g., John C. Coffee, Jr., Liquidity Versus Control: The Institutional Investor as Corporate Monitor, 91 ColuM. L. REV. 1277, 1360-61 (1991); Gilson \& Kraakman, supra note 227, at 883-92; Christian J. Meier-Schatz, Corporate Governance and Legal Rules: A Transitional Look at Concepts and Problems of Internal Management Control, 13 J. CORP. L. 431, $471-73$ (1988); Nell Minow, Shareholders, Stakeholders, and Boards of Directors, 21 STETSON L. REv. 197, 231-32 (1991); John Pound, The Promise of the Governed Corporation, HARv. BUS. REV., Mar.-Apr. 1995, at 89; A.A. Sommer, Jr., Corporate Governance: The Search for Solutions, 26 U.S.F. L. REV. 695, 711 (1992). 
to have a seat on the board, ${ }^{233}$ and insulating the board from shareholder pressure. ${ }^{234}$

The board of directors of Kmart during the Antonini years did not adopt many of the proposals of the corporate governance reform movement; indeed, the consolidation of power in Antonini's hands raises serious questions about the board's ability to act independently. The first section below examines the possible effects of Kmart's decision to consolidate the positions of CEO and Chairman. The four sections that follow discuss the effectiveness of outside directors, incentive compensation, debt policy, and dividend policy in addressing Kmart's corporate governance problem.

\section{a. Separation of CEO and Chairman Positions}

Proposals for separating the positions of CEO and chairman of the board are common in corporate governance scholarship. ${ }^{235}$ The intuition behind these proposals is straightforward: If the board of directors is to act as an effective monitor of senior management, it must be independent of senior management. As Michael Jensen recently stated:

The function of the chairman is to run board meetings and oversee the process of hiring, firing, evaluating, and compensating the CEO. Clearly the CEO cannot perform this function apart from his or her personal interest. Without the direction of an independent personal leader, it is much more difficult for the board to perform its critical function. Therefore, for the board to be effective, it is important to separate the CEO and Chairman positions. ${ }^{236}$

Despite the intuitive appeal of separation, very few American corporations have separated the positions. ${ }^{237}$ In a recent study of

233. See, e.g., LOWENSTEIN, supra note 176, at 205-18; Jayne W. Barnard, Shareholder Access to the Proxy Revisited, 40 CATH. U. L. REV. 37, 39-41 (1990).

234. See, e.g., Lipton \& Rosenblum, supra note 135, at 224-52 (proposing quinquennial elections of directors to enable them to take a longer term view); Lawrence E. Mitchell, A Critical Look at Corporate Governance, 45 VAND. L. REV. 1263, 1273-83 (1992) (proposing the elimination of shareholder elections and recasting the board as a mediating body among the various corporate stakeholders).

235. See, e.g., Roberta S. Karmel, Is It Time For a Federal Corporation Law?, 57 BROOK. L. REV. 55, 59 (1991); Walter J. Salmon, Crisis Prevention: How to Gear Up Your Board, HARV. BUS. REV., Jan.-Feb. 1993, at 68, 72.

236. Jensen, supra note 203 , at 866 .

237. One of the most visible companies with separate CEO and chairman positions during recent years has been General Motors. See Judith H. Dobrzynski, Jack and John: 2 for the Road at G.M., N.Y. TIMES, July 9, 1995, at D1. General Motors recently announced, however, that the positions would both be held by John F. Smith, Jr. See 
737 large corporations, James A. Brickley, Jeffrey L. Coles, and Gregg Jarrell found that over eighty percent have one person holding both the CEO and chairman titles. ${ }^{238}$ Of the ninety-three firms in the sample that had separated the CEO and chairman positions, over eighty percent had chairmen who were former CEOs, founders, or other top officers of the company or an affiliate; therefore, only $2.57 \%$ of the entire sample had chairmen who were not current or former employees of the company. 239

Antonini was Chairman, CEO, and President of Kmart from 1987 until his ouster as Chairman in January 1995. ${ }^{240}$ With respect to Kmart's corporate governance problem, the failure to separate the positions of CEO and chairman might have had a dramatic effect. Although empirical studies of the effects on corporate performance of separating the positions of $\mathrm{CEO}$ and chairman have yielded mixed results, ${ }^{241}$ there is substantial support for the proposition that independent directors are more likely than inside directors to remove ineffective managers. ${ }^{242}$

\section{b. Outside Directors}

Outside directors-those who are not otherwise employed by the company for whom they are directors-were "discovered" in the early 1970 s, and the number of outside directors on boards of American corporations has increased dramatically over time. ${ }^{243}$ The virtue of outside directors is their presumed independence from incumbent

Robert L. Simison \& Rebecca Blumenstein, GM Decides One Head Is Better Than Two, WALI ST. J., Dec. 5, 1995, at B1 (concluding that "GM's move to reunite the two posts underscores that American boards often turn to split leadership only in an emergency"). 238. James A. Brickley et al., Corporate Leadership Structure: On the Separation of the Positions of CEO and Chairman of the Board 13 (U. of Rochester Financial Research and Policy Studies Working Paper Series No. 95-02, 1995).

239. Id.

240. Antonini's successor, Floyd Hall, was given the same three titles. Christina Duff \& Joann S. Lublin, Kmart Names Retailer Hall To 3 Top Posts, WALl ST. J., June 6, 1995, at $\mathrm{A} 3$.

241. Compare Lynn Pi \& Stephen G. Timme, Corporate Control and Bank Efficiency, 17 J. BANK. \& FIN. 515 (1993) (finding that banks that separate the Chairman and CEO positions tend to outperform banks where the positions are combined); Paula L. Rechner \& Dan R. Dalton, CEO Duality and Organizational Performance: A Longitudinal Analysis, 12 STRATEGIC MGMT. J. 155 (1991) (finding higher performance in firms opting for independent leadership) with Brickley et al., supra note 238, at 22-28 (finding no systematic association between leadership structure and accounting returns and no systematic effects on stock prices from changes in leadership structure).

242. See, e.g., James D. Cox, The ALI, Institutionalization, and Disclosure: The Quest for the Outside Director's Spine, 61 GEO. WASH. L. REV. 1233, 1241 (1993) (citing studies).

243. MONKS \& MiNow, supra note 29 , at 202-04. 
management, which theoretically allows them to guard against managerial abuse and to monitor for managerial incompetence. Because of the presumed effectiveness of outside directors, courts have relied heavily on outside directors to approve transactions involving potential conflicts of interest between the shareholders and management. ${ }^{244}$

Although corporate scholars now have reached a virtual consensus on the need for outside directors ${ }^{245}$ and most public corporations have a substantial percentage of outside directors on their boards, ${ }^{246}$ commentators increasingly have come to recognize that not all outside directors are created equal because many outside directors are not truly independent of the companies on whose boards they serve. ${ }^{247}$ Even truly independent directors operate subject to many practical limitations on their effectiveness: lack of time to perform their duties; inability to have meaningful participation from all directors because boards typically are large; complexity of information necessary to make decisions; lack of cohesiveness within boards; dependence on officers of the company for information (especially when the CEO of the company also serves as the chairman of the board of directors); and confusion about goals and ultimate accountability. ${ }^{248}$ Perhaps predictably, therefore, studies of the

244. For a comprehensive review of situations in which the law currently relies on outside directors, including interested director and officer transactions, derivative litigation, and takeover defense, see Laura Lin, The Effectiveness of Outside Directors as a Corporate Governance Mechanism: Theories and Evidence, 90 Nw. U. L. REV. (forthcoming 1996).

245. Gilson \& Kraakman, supra note 237, at 873 ("At this point in the quest [for the corporate equivalent of the Holy Grail], one solution to the accountability problem has attained the status of conventional wisdom:" that independent outside directors elected by shareholder should monitor management). For endorsements of independent directors, See AMERICAN BAR ASSOCIATION, CORPORATE DIRECTOR'S GUIDEBOOK (2d ed. 1994), in 49 Bus. LAw. 1243, 1272 (1994); ALI PRINCIPLES, supra note 27, at $\S 3$ A.01; EISENBERG, supra note 223, at 170-85; THE BUSINESS ROUNDTABLE, Corporate Governance and American Competitiveness, 46 Bus. LAW. 241, 249 (1990).

246. LORSCH \& MACIVER, supra note 224, at 17-18.

247. For example, nominally independent directors may be lawyers or bankers who have been retained by the corporation. See Stephen M. Bainbridge, Independent Directors and the ALI Corporate Governance Project, 61 GEO. WASH. L. REV. 1034, 1059 (1993); Barry D. Baysinger \& Henry N. Butler, Corporate Governance and the Board of Directors: Performance Effects of Changes in Board Composition, 1 J.L. ECON. \& ORG. 101, 109-10 (1985); Victor Brudney, The Independent Director-Heavenly City or Potemkin Village?, 95 HARV. L. REV. 597, 610-13 (1982). For a review of arguments that outside directors inevitably are controlled by management, see Lin, supra note 244, at 15-20 (discussing the "managerial hegemony theory" of outside directors).

248. See Jensen, supra note 203 , at $862-67$ (discussing the factors that make it difficult for boards to carry out monitoring function); Lipton \& Lorsch, supra note 227, at 64-67 (same); see also LORSCH \& MACIVER, supra note 224, at 84-89 (same); Cox, supra note 
effectiveness of outside directors in improving firm performance have shown mixed results. ${ }^{249}$

Perhaps the most important attribute of directors for the purposes of this Article is that they are the only corporate governance mechanism besides the market for corporate control that has any power to solve the problem of managerial incompetence. Commentators dispute the nature of the outside directors' role, but broad agreement exists that outside directors are in the best position to monitor management. ${ }^{250}$ In addition, commentators agree that certain functions beyond the traditional functions of a board (e.g., selecting senior management, establishing an incentive compensation program, acting as advisors when called upon by senior management, and assuming control of the corporation in an emergency) ${ }^{251}$ should be part of the outside director package, particularly the active monitoring of senior management. ${ }^{252}$

Although Kmart's board of directors consisted primarily of outside directors, those directors were not particularly active. According to reports in the financial press, Kmart's board played almost no role in the formation of Kmart's corporate strategy. ${ }^{253}$ In

242 , at $1235-38$ (same).

249. For a current review of empirical evidence on the effectiveness of outside directors, see Lin, supra note 244.

250. See EISENBERG, supra note 223, at 149-68; Bainbridge, supra note 247, at 1053-57; Gilson \& Kraakman, supra note 227, at 873. But see Cox, supra note 242, at 1273 (concluding that arguments that outside directors can contribute to improved governance beyond the curbing of managerial overreaching are a "false hope").

251. For studies of the workings of boards of directors, see LORSCH \& MACIVER, supra note 224; MYLES L. MACE, DIRECTORS: MYTH AND REALITY (1971).

252. See, e.g., AMERICAN BAR ASSOCIATION, CORPORATE DIRECTOR'S GUIDEBOOK (2d ed. 1994), in 49 BUS. LAW. 1243, 1249-50 (listing proposed oversight responsibilities); ALI PRINCIPLES, supra note 27, at $\S 3.02$ (listing functions and powers of the board of directors); EISENBERG, supra note 223, at 156-68 (describing the functions of the board of directors); LORSCH \& MACIVER, supra note 224, at 181-82 (emphasizing the importance of evaluating the CEO and using outside experts); Jensen, supra note 203, at 862-63 (discussing need for improving the board's ability to "hire, fire, and compensate the CEO").

253. See, e.g., Adam Bryant, Kmart's Chief Turns to Plan B, N.Y. TiMEs, June 16, 1994, at D1 (describing Antonini's role in proposing spinoffs of specialty retailers to the board after shareholders voted against the targeted stock proposal); Arthur Markowitz, Why Kmart's survival matters, DISCOUNT STORE NEWS, Oct. 3, 1994, at 16 (raising questions about "the relationship between chairman Joseph Antonini and the up-to-now compliant board of directors and Antonini's position as someone who maps out both Kmart's strategy and its tactics-over-seeing both the long-term and the day-to-day operations"); Kmart Restructures Merchandising Division: Consolidations to Reflect Joe Antonini's Strategies, DiscounT STORE NEwS, Jan. 7, 1991, at 3 (stating that changes in a restructuring "directly relate to [Kmart's] efforts to execute chairman Joseph Antonini's 
addition, at least until the failed proxy contest over the targeted stock proposal, Antonini was said to rule Kmart with little apparent monitoring by the board. ${ }^{254}$ Moreover, Kmart's board appeared to suffer limitations on its ability to act: the board was large (thirteen directors), ${ }^{255}$ only one of ten outside directors (Donald Perkins) had significant retailing experience, ${ }^{256}$ all outside directors owned only nominal equity stakes in $\mathrm{Kmart},{ }^{257}$ and they met infrequently. ${ }^{258}$ Although Kmart had a nominating committee of the board consisting of six outside directors, ${ }^{259}$ it is not clear whether a nominating

strategies for the '90s. Antonini views centralized merchandising-wherein products are replenished at headquarters using computerized point-of-sale and satellite technology-as key to its ability to maintain in-stock positions at the stores and to build sales").

254. The board's apparent lack of involvement inspired shareholders to take a more active role. See Stephanie Strom, Kmart's Spinoff Plan Drawing Opposition, N.Y. TIMES, June 1, 1994, at D1 (prior to the vote on the targeted stock proposal, James Martin, executive vice president of College Retirement Equities Fund (CREF), said, "In CREF's view, the directors of Kmart have not taken enough of a proactive or independent role throughout this decline, thereby failing to fulfill their oversight duties"); Stephanie Strom, Chairman Loses Title At Kmart, N.Y. TIMES, Jan. 18, 1995, at D1 (after Antonini's ouster as Chairman, SWIB's James Severance recalled, "What galvanized us to act last June was that the board wasn't as involved and active as it should have been.").

255. In addition to Antonini, two other executive officers of Kmart served as directors: Richard S. Miller, Executive Vice President, Super Kmart Centers and Joseph R. Thomas, Executive Vice President, U.S. Kmart Stores. 1994 PROXY STATEMENT, supra note 42, at 30,31 .

256. The following were Kmart's 10 outside directors at the time of Antonini's ouster and a description of their primary occupations: Lilyan H. Affinito, Former Vice Chairman of the Board of Maxxam Group Inc.; Joseph A. Califano, Jr., Chairman and President, Center on Addiction and Substance Abuse at Columbia University, author, and health care consultant; Willie D. Davis, President of All Pro Broadcasting, Inc.; Enrique C. Falla, Executive Vice President and Chief Financial Officer of The Dow Chemical Company; Joseph P. Flannery, Chairman of the Board, President and Chief Executive Officer of Uniroyal Holding, Inc.; David B. Harper, President, David B. Harper Management Co., Inc. and President, New Age Bancorporation; F. James McDonald, Retired President and Chief Operating Officer of General Motors Corporation; J. Richard Munro, Chairman of the Executive Committee of Time Warner Inc.; Donald S. Perkins, Retired Chairman of the Board of Jewel Companies, Inc.; Gloria M. Shatto, President, Berry College. Id. at 2931.

257. The following are the number of shares held by Kmart's outside directors as of March 1, 1994: Lilyan H. Affinito, 4,709 shares; Joseph A. Califano, Jr., 2,968 shares; Willie D. Davis, 2,052 shares; Enrique C. Falla, 2,101 shares; Joseph P. Flannery, 3,098 shares; David B. Harper, 1,968 shares; F. James McDonald, 8,430 shares; J. Richard Munro, 2,923 shares; Donald S. Perkins, 8,423 shares; and Gloria M. Shatto, 2,052 shares. Id. at 31. As of the same date, Antonini held 1,140,032 shares, Miller held 498,627 shares, and Thomas held 642,523 shares, all including stock options and restricted stock. Id.

258. There were 17 meetings of the Board during the fiscal year ended January 26 , 1994. Id. at 33.

259. Id. 
committee can make a significant contribution to the board's independence. ${ }^{260}$ It is not surprising, therefore, that when the board acted to replace Antonini as Chairman and then as CEO, it was only after several months of intense pressure by institutional investors. ${ }^{261}$

Based on the foregoing facts, it would be difficult to assume that Kmart's board of directors fulfilled its role as an independent monitor of Antonini's performance. But it also might be imprudent to assume the contrary. Comments by Chairman Donald Perkins following Antonini's resignation suggest that at least Perkins did not act against Antonini earlier because Perkins believed in Antonini's strategy for the company. ${ }^{262}$ It is possible, therefore, that the board delayed moving against Antonini not because it lacked independence, but because it believed that Antonini was on the right course.

\section{c. Executive Compensation}

Executive compensation generated much political attention in the first half of this decade, culminating in initiatives by Congress ${ }^{263}$ and the $\mathrm{SEC}^{264}$ to discourage perceived excesses in compensation. The political controversy surrounding executive compensation emanated from popular outrage over the absolute dollar levels of CEO compensation; CEO compensation typically is a trivial amount compared with corporate earnings. From a corporate governance

260. See Cox, supra note 242 , at 1243 .

261. Outside directors have proven more effective than inside directors in displacing ineffective managers. Michael S. Weisbach, Outside Directors and CEO Turnover, $20 \mathrm{~J}$. FIN. ECON. 431, 458-59 (1988). It strains credulity to credit Kmart's outside directors with ousting Antonini, however, since they were criticized behind the scenes and in the national press for months before deciding to act.

262. Perkins left no doubt that the shareholders were the driving force behind Antonini's ouster, saying, "The shareholders have made themselves very clear, and we have responded to them. ... The shareholders are every reason for this." Stephanie Strom, Kmart Chief, Under Siege, Resigns Post, N.Y. TIMES, Mar. 22, 1995, at D1. Perkins then noted that he had assumed the position of Chairman in an attempt to fend off pressure from investors while Antonini and his management team executed their strategy: "I hoped that by taking the chairman role that the large investors would give Joe and his management group time to do the things they had to do to be successful. . . . But it has become apparent that Joe doesn't have that time." Id. Perkins's opinion probably carried great weight with the other directors, considering that he was the only director with retailing experience and was chosen by the other directors to replace Antonini as chairman.

263. Revenue Reconciliation Act of 1993, Sec. 13222, Pub. L. No. 103-66, 103d Cong., 1st Sess., approved Aug. 10, 1993.

264. Executive Compensation Disclosure, Exchange Act Release Nos. 33-6962, 34 31327, IC-19032, 57 Fed. Reg. 48,126 (1992) (to be codified at 17 C.F.R. $\$ \S 228,229,240$, 249). 
perspective, absolute dollar levels are relevant only to the extent they affect the incentives of managers to act in the interests of shareholders.

Designing an effective compensation scheme from a corporate governance perspective can be extremely complicated. As Milgrom and Roberts note in the context of their discussion of capital markets, for example, compensation that is tied to stock price may provide an incentive for short-term management. ${ }^{265}$ Ronald Gilson identified several principles to guide the design of an effective compensation scheme but concluded that "[i]mplementing these general principles ... present[s] difficult problems for which there are only judgments, not determinative answers." 266

Whether because of difficulty of design or other reasons, the effectiveness of executive compensation as a monitoring device has been questioned-both by those who claim that compensation levels are too high and those who claim they are not high enough-on grounds that compensation usually does not adequately reflect the executive's performance. ${ }^{267}$ Complicating the debate further is the fact that no one is sure how well incentive compensation of top executives improves corporate performance. Although the empirical evidence suggests that as corporations increase the sensitivity of salary and bonus to current corporate performance, future performance improves, ${ }^{268}$ the link between long-term incentive plans and firm performance has not yet been established. ${ }^{269}$

265. See MILGROM \& RoBERTS, supra note 172 , at $436-37,471$.

266. Gilson, supra note 22 , at 669.

267. See, e.g., MILGROM \& ROBERTS, supra note 172, at 438; Charles M. Elson, Executive Overcompensation-A Board-Based Solution, 34 B.C. L. REV. 937, 945-49 (1993); Michael C. Jensen \& Kevin J. Murphy, Performance Pay and Top-Management Incentives, 98 J. POL. ECON. 225, 261-62 (1990); Susan L. Martin, The Executive Compensation Problem, 98 DICK. L. REV. 237, 251-53 (1994).

268. John M. Abowd, Does Performance-Based Managerial Compensation Affect Corporate Performance?, 43 INDUS. \& LAB. REL. REV. 52S, 52S-55S (1990).

269. See MILGROM \& ROBERTS, supra note 172 , at 442 . A recent study goes some distance toward this conclusion, showing that executive pay responds to long-term performance. John F. Boschen \& Kimberly J. Smith, You Can Pay Me Now and You Can Pay Me Later: The Dynamic Response of Executive Compensation to Firm Performance, 68 J. BUS. 577 (1995). Boschen and Smith studied a longtime series of CEO compensation data and concluded that "a $10 \%$ increase in real returns is associated with a contemporaneous compensation response of only $0.3 \%-0.5 \%$, but a cumulative response of $3 \%$ $5 \%$." Id. at 578. In addition, the authors described the pattern of compensation responses to performance innovations as "hump-shaped," with a small contemporaneous response followed by four years of large significant responses, after which the responses decrease. Id. at 578, 595-600. Finally, the authors observed that the cumulative sensitivity of pay to performance has increased over time and that the time period over which the response 
It is impossible to say whether Antonini's compensation package was optimal, but there is no question that Kmart's board of directors attempted to provide Antonini with an incentive pay arrangement that would encourage good performance. Compensation of Kmart executives had four key components: salaries, incentive bonuses, stock purchases, and stock options. ${ }^{270}$ All four components are intended to reflect performance, but the incentive bonuses (and resulting stock purchases, described below) are most sensitive to changes in the company's performance.

The Compensation and Incentives Committee of Kmart's board of directors typically set a salary goal for executive officers of Kmart at the 50th percentile of salaries for comparable positions based on an annual executive compensation survey in which Kmart and other "multi-billion dollar U.S. retailers" participate. ${ }^{271}$ For example, Antonini's 1994 salary was set at $\$ 923,000$, which was at the fiftieth percentile. ${ }^{272}$ Once established, the salary did not vary based on Kmart's performance, and, as shown by the table below, tended to increase regardless of the previous year's performance.

In addition to salaries, Kmart executives were given the opportunity to receive annual incentive bonuses based on a percentage of the salary range midpoint for a comparable position within the companies participating in the annual executive compensation survey. ${ }^{273}$ For example, in 1994 Antonini received a targeted bonus opportunity equal to sixty-seven percent of such salary range midpoint. ${ }^{274}$ Unlike salaries, incentive bonuses are completely dependent on the company's performance, and Antonini received no bonuses during his last two years at Kmart. The following chart shows Antonini's salaries and incentive bonuses and Kmart's consolidated net income for each full year of his tenure:275

occurs has lengthened since the 1950s. Id. at 602-03.

270. See 1995 PROXY STATEMENT, supra note 42, at 15 (Compensation and Incentives Committee Report on Executive Compensation).

271. Id.

272. See id. at 15-16.

273. Id.

274. See id.

275. Compensation figures in the table were gathered from Kmart's Proxy Statements from 1989-1995. Separate figures for "Salary" and "Bonus" were not provided for 1988. Net income figures in the table were gathered from Kmart's Annual Reports 1989-1995. Note that the net income for 1989 was significantly decreased by a one-time charge of $\$ 422$ million after tax for Kmart restructuring and other charges. Excluding the one-time charge, net income was $\$ 745$ million. 1989 ANNUAL REPORT, supra note 43, at 23. 


\begin{tabular}{|c|c|c|c|c||}
\hline \hline Year & Salary & Bonus & $\begin{array}{c}\text { Total Short- } \\
\text { Term Com- } \\
\text { pensation }\end{array}$ & $\begin{array}{c}\text { Kmart's } \\
\text { Consolidated } \\
\text { Net Income } \\
\text { (Loss) }\end{array}$ \\
\hline \hline 1994 & $\$ 923,000$ & $\$ 0$ & $\$ 923,000$ & $\$ 296,000,000$ \\
\hline 1993 & $\$ 893,000$ & $\$ 0$ & $\$ 893,000$ & $(\$ 974,000,000)$ \\
\hline 1992 & $\$ 850,000$ & $\$ 604,901$ & $\$ 1,454,901$ & $\$ 941,000,000$ \\
\hline 1991 & $\$ 750,000$ & $\$ 795,784$ & $\$ 1,545,784$ & $\$ 859,000,000$ \\
\hline 1990 & $\$ 600,000$ & $\$ 392,625$ & $\$ 992,625$ & $\$ 756,000,000$ \\
\hline 1989 & $\$ 525,000$ & $\$ 373,928$ & $\$ 898,928$ & $\$ 323,000,000$ \\
\hline 1988 & $\mathrm{n} / \mathrm{a}$ & $\mathrm{n} / \mathrm{a}$ & $\$ 925,000$ & $\$ 303,000,000$ \\
\hline
\end{tabular}

In 1994 shareholders approved a Management Stock Purchase Plan, ${ }^{276}$ which provides that at least twenty percent of all annual incentive bonuses must be used and up to $100 \%$ of such bonuses may be used to purchase shares of Common Stock. ${ }^{277}$ Because Antonini did not earn an incentive bonus in 1994, he was not eligible to purchase shares under the plan.

Kmart also maintained a stock option plan, under which certain Kmart executives were granted stock options annually to enable those executives "to develop and maintain a substantial stock ownership position in ... [Kmart's] Common Stock, and create[] a direct link between executive compensation and stockholder return-as the benefit of a stock option cannot be realized unless the stock price appreciates."278 Under the plan, executives were granted options "whose present value (under the Black-Scholes [Stock Option Pricing] model) is equal to a percentage of the salary range midpoint for a comparable position within the companies participating in the ... annual executive compensation survey-with the largest number of option shares being granted to the CEO."279 In 1994 Antonini was granted options to purchase 125,000 shares of Kmart common

276. See 1995 PROXY STATEMENT, supra note 42, at 16.

277. 1994 PROXY STATEMENT, supra note 42, at 113.

278. 1995 PROXY STATEMENT, supra note 42 , at 16.

279. $I d$. 
stock, which placed him "at about the 50th percentile of long-term compensation awards for chief executive officers of retailers participating in the ... annual executive compensation survey."280 That was the same number of options that he received in 1993, but they had a significantly lower valuation. ${ }^{281}$

With respect to Kmart, then, the board apparently attempted to provide Antonini with personal financial incentives, although the ultimate effect of those incentives is impossible to measure. Incentive compensation ensures that an incompetent manager will receive less than a competent manager, but that is undoubtedly small satisfaction to shareholders who suffer the results of incompetent management. No executive compensation scheme yet implemented has been able to correct managerial incompetence.

\section{d. Dividend Policy}

A company's dividend policy determines how much of the company's earnings will be distributed to shareholders and how much will be retained by the company for reinvestment. The board of directors establishes dividend policy. ${ }^{282}$ Financial economists have theorized that investors should be indifferent or hostile toward dividends, ${ }^{283}$ and that managers have strong incentives to retain earnings within the company, resulting in the familiar problem of free cash flow. ${ }^{284}$ Nevertheless, both shareholders and managers act as if they care about, or even desire, dividends. Fischer Black labelled this dissonance between theory and practice the "dividend puzzle."285

280. Id. at 17.

281. Id. at 16-17.

282. See, e.g., DEL. CODE ANN., tit. 8, § 170 (1995); MODEL BUSINESS CORP. ACT $\S$ 6.40(a) (1984). States with a legal capital rule place limits on the amount of dividends the board may declare. For a description of legal capital rules, see BAYLESS MANNING \& JAMES HANKS, LEGAL CAPITAL (3d ed. 1990).

283. The classic work proposing the indifference theorem based on the assumption of "perfect capital markets" is Merton H. Miller \& Franco Modigliani, Dividend Policy, Growth, and the Valuation of Shares, 34 J. Bus. 411, 412 (1961). For a discussion of dividend policy when the assumption of perfect capital markets is removed, see ROSS ET AL., supra note 146 , at 530-35.

284. See Jensen, supra note 208, at 323 (defining "free cash flow" as the amount of cash flow in excess of what a company can profitably reinvest).

285. Fischer Black, The Dividend Puzzle, J. PORTFOLIO MGMT., Winter 1976, at 5, 5; see also Steven V. Mann, The Dividend Puzzle: A Progress Report, Q. J. Bus. \& ECON., Summer 1989, at 3 (discussing the tax and information effects of dividends). 
Although scholars have suggested several possible solutions to the dividend puzzle, ${ }^{286}$ the one that is of most interest in the present context is the agency-cost explanation, which holds that "dividends set in motion mechanisms that reduce the agency costs of management."287 The agency-cost explanation of dividends rests on two assumptions: (1) that the costs to shareholders of free cash flow exceed the costs of paying dividends; and (2) that shareholders are aware of management's proclivity for free cash flows. Because of this awareness, "investors rationally discount a firm's stock price to reflect the expected costs of this form of managerial opportunism. Management thereby acquires an incentive to promise investors credibly that management discretion over dividend policy will not be abused."288 By paying a substantial dividend, management decreases the amount of free cash flow, thus reducing agency costs.

But paying a substantial one-time dividend does not bind management to reductions in agency costs; since management has sole discretion as to dividend policy, "managers can opportunistically reduce or omit dividend payouts at any time."289 For this reason, managers attempt to bind themselves by making a credible commitment to stable dividend payments. ${ }^{290}$ As managers develop a

286. In addition to the agency-cost explanation, an extensive literature suggests that changes in dividend policy signal management's private information about future cash flows. Miller and Modigliani suggested this possibility. Miller \& Modigliani, supra note 283 , at 430 . For the first empirical work explicitly addressing the signaling hypothesis, see Sudipto Bhattacharya, Imperfect Information, Dividend Policy, and "The Bird in the Hand" Fallacy, 10 BELL J. ECON. 259 (1979). Later work includes Paul M. Healy \& Krishna G. Palepu, Earnings Information Conveyed by Dividend Initiations and Omissions, 21 J. FIN. ECoN. 149 (1988); Kose John \& Joseph Williams, Dividends, Dilution, and Taxes: $A$ Signaling Equilibrium, 40 J. FIN. 1053 (1985); Larry H.P. Lang \& Robert H. Litzenberger, Dividend Announcements: Cash Flow Signalling vs. Free Cash Flow Hypothesis?, 24 J. FIN. ECON. 181 (1989); Merton H. Miller \& Kevin Rock, Dividend Policy under Asymmetric Information, 40 J. FIN. 1031 (1985).

Another explanation for why investors care about dividends stems from differential tax rates. Investors in a low tax bracket may desire dividends, while investors in high tax brackets will avoid them. See Fischer Black \& Myron Scholes, The Effects of Dividend Yield and Dividend Policy on Common Stock Prices and Returns, 1 J. FIN. ECON. 1, 2-3 (1974); Merton H. Miller \& Myron S. Scholes, Dividends and Taxes, 6 J. FIN. ECON. 333, 334 (1978).

287. Frank H. Easterbrook, Two Agency-Cost Explanations of Dividends, 74 AM. ECON. REV. 650, 655 (1984); see also Michael S. Rozeff, Growth, Beta and Agency Costs as Determinants of Dividend Payout Ratios, 5 J. FIN. RES. 249 (1982) (concluding that agency costs influence dividend policy).

288. Zohar Goshen, Shareholder Dividend Options, 104 YALE L.J. 881, 888-89 (1995).

289. Id. at 889 .

290. That managers seek stable dividends is well supported by the empirical evidence. For the initial work on this issue, see John Lintner, Distribution of Incomes of Cor- 
reputation for keeping their dividend commitment, investors will pay more for the company's stock because expected agency costs are reduced. Finally, "[a]s the reputation investment increases ... management's potential benefit from opportunistically cutting dividends falls below the value of the squandered reputation investment." 291

The agency-cost explanation of dividends suggests that managers maintain a stable dividend policy to reduce agency costs, thus increasing the value of the firm. ${ }^{292}$ But a stable dividend policy also has costs, including the transaction costs associated with raising new capital, the taxes paid by shareholders if more than the optimal amount of dividends are maintained, and the costs of financial inflexibility. ${ }^{293}$

The law relating to dividend policy is very deferential to managers. ${ }^{294}$ Zohar Goshen recently suggested that because managers tend to adopt suboptimal dividend policies, the law should provide for mandatory shareholder dividend options, thus encouraging dividend policies closer to the optimal level. ${ }^{295}$ Dividend options would allow the directors to retain control over fixing the distribution date and the payout ratio, but would allow each shareholder to choose-independently of the other shareholders-between receiving a cash dividend or a stock dividend. ${ }^{296}$ Although dividend options face legal obstacles (primarily the fact that the tax rules governing dividends would tax both the cash dividends and stock dividends as current income) ${ }^{297}$ and practical obstacles (including identifying the level of earnings that must be distributed and preserving the ability

porations Among Dividends, Retained Earnings, and Taxes, 46 AM. ECON. REV. 97 (1956). Lintner suggested, based on interviews with corporate managers, that firms have long-run target dividend payout ratios and that maintaining stable dividends was extremely important to managers. Id. at 99-103. Lintner argued that managers were likely to change dividends only if changes in earnings were perceived as permanent rather than temporary. Id.

291. Goshen, supra note 288 , at 891 .

292. Id. at 892 .

293. Id. at 892-93.

294. State courts have ruled that dividend decisions are within the sole discretion of directors; therefore, shareholders attempting to challenge managers must overcome the business judgment rule. For two oft-cited cases on this issue, see Sinclair Oil Corp. v. Levien, 280 A.2d 717, 722-23 (Del. 1971) (upholding corporation's decision to pay dividends); Dodge v. Ford Motor Co., 170 N.W. 668 (Mich. 1919) (overturning corporation's decision not to pay dividends).

295. Goshen, supra note 288 , at 884 .

296. Id. at 903.

297. Id. at 906-08. 
of debt holders of the company to specify dividend levels), ${ }^{298}$ Goshen argues that they would achieve the benefits of a stable dividend policy at a lower cost to the firm. ${ }^{299}$

Dividends were a constant source of anxiety during Antonini's tenure. Prior to 1994, Kmart had increased dividends for twenty-nine straight years. ${ }^{300}$ Despite reports during the proxy contest that Kmart's board was reconsidering the dividend policy, ${ }^{301}$ the board refused to budge. Even after Antonini's ouster as Chairman, the board reaffirmed its dividend policy even though profits did not cover dividend payments. ${ }^{302}$ At that time, one portfolio manager was quoted as saying, "The day Kmart substantially cuts the dividend is the day I'll start taking them seriously."303 Kmart finally reduced its dividend by half in April $1995^{304}$ and completely eliminated the remaining dividend in December 1995 as part of an agreement with creditors. $^{305}$

With respect to Kmart's corporate governance problem, dividend policy may have had a profound, albeit indirect, effect by reducing the amount of cash available to Antonini. Because Antonini's plans for Kmart contemplated vast expenditures to update the discount stores and expand the specialty stores, a dividend policy that required large distributions of cash to shareholders left Antonini one viable option for obtaining the money necessary to execute his strategies: access the capital markets. Unfortunately for Antonini, the capital markets were not hospitable to Kmart common stock, Kmart already had a significant amount of public indebtedness, and ratings agencies were poised to lower Kmart's debt rating. ${ }^{306}$ In that environment, the targeted stock proposal must have seemed like a godsend. After all, targeted stock was designed for companies that felt their common

298. Id. at 918-26.

299. For Goshen's discussion of the costs and benefits of dividend options, see $i d$. at 903-06.

300. Shirley A. Lazo, Attention, Kmart Shareholders . . Beleaguered Retailer Won't Raise Payout, BARRON's, Mar. 21, 1994, at 46.

301. See Christina Duff, Kmart May Be Facing Dividend Dilemma, WALL ST. J., June 3, 1994, at C1, C2.

302. Duff \& Lublin, supra note 5, at A3.

303. Id.

304. Christina Duff, Kmart Halves Payout Ahead of Poor Results, WaLl ST. J., Apr. 26, 1995, at A3.

305. Robert Berner, Kmart Ends Payout, Sets Bond Accord, WALL ST. J., Dec. 21, 1995, at A3.

306. For a description of actions by the ratings agencies after the targeted stock proposal, see supra notes 84-86 and accompanying text. 
stock was undervalued by the market. ${ }^{307}$ But as described above, the market never had an opportunity to value the targeted stock because the existing $\mathrm{Kmart}$ shareholders rebelled against the proposal. Kmart's dividend policy, therefore, appears to have been instrumental in the creation of the targeted stock proposal, the defeat of which precipitated Antonini's ultimate downfall. ${ }^{308}$

\section{e. Debt Policy}

A company's capital structure (i.e., the relative levels of debt and equity within a firm) is a matter that corporate law places almost exclusively within the control of the board of directors. Whether the choice of capital structure affects the value of the firm has been a source of much study by financial economists. ${ }^{309}$ The starting point for modern analysis of capital structure is a 1958 article by Franco Modigliani and Merton Miller (MM), ${ }^{310}$ which argued-contrary to the traditional viewpoint-that capital structure is irrelevant to the value of the firm. MM's analysis rests on two crucial concepts: (1) because shareholders of a corporation are able to obtain any mix of debt and equity on their own that the corporation could obtain on

307. See TARGETED STOCK: AN EXECUTIVE SUMMARY 1-2 (1994) (brochure published by Lehman Brothers (investment bank), Price Waterhouse (accounting firm), and Simpson Thacher \& Barlett (law firm)) (on file with author):

In the current environment, companies often experience an equity market penalty for unrelated businesses (the so-called "conglomerate discount"); however, there are few alternatives available for avoiding taxation on a separation of these businesses. Adding further complexity, a legal separation of a company may first require lengthy negotiations with creditors and heightened antitrust scrutiny has increased the uncertainty of completing intra-industry transactions. ...

Traditional restructuring vehicles-such as spin-offs, initial public offering "carve outs" and divestitures-can help a company achieve ... restructuring goals, but often suffer from tax, corporate governance or other limitations.

A more flexible alternative, Targeted Stock, can act as an effective restructuring tool without many of the constraints of other options. Targeted Stock's versatility provides corporate management with unique strategic restructuring flexibility, while addressing the concerns of both equity and fixed Id. income investors.

308. When faced with debt agreements providing for an event of default if Kmart's credit rating fell below investment grade, Kmart finally agreed to discontinue dividend payments. See Robert Berner, Kmart Ends Payout, Sets Bond Accord, WALl ST. J., Dec. 21,1995 , at $\mathrm{A} 3$.

309. For an introduction to issues relating to capital structure, see BREALEY \& MYERS, supra note 146, at 397-414, 421-49; Ross ET AL., supra note 146, at 415-44, 451-79.

310. Franco Modigliani \& Merton H. Miller, The Cost of Capital, Corporation Finance and the Theory of Investment, 48 AM. ECON. REV. 261 (1958). 
their behalf, corporate leverage has no value to investors and will not affect the amount investors will pay for the corporation's securities; and (2) arbitrage extinguishes any price differences between companies based on capital structure as traders command prices reflecting fundamental values.

MM's analysis assumes "perfect capital markets," meaning that information is costless and readily available to all investors, that securities trades do not entail transactions costs, that all securities are infinitely divisible, and that investors trade rationally. But capital markets are not perfect, and three important imperfections suggest that capital structure may affect firm value. First, because payments of interest on debt are deductible, corporate taxes are reduced by the issuance of debt as opposed to equity. ${ }^{311}$ This "tax shield" suggests that as levels of debt increase, the value of the firm increases. But as levels of debt increase, a second imperfection-namely, bankruptcy costs-enters the analysis. ${ }^{312}$ The higher a firm's leverage, the greater the risk of bankruptcy and the lower the value of the firm. A third market imperfection is the existence of agency costs of debt. ${ }^{313}$ As the amount of debt increases, the amount of monitoring required by debt holders increases. Of course, monitoring involves costs, which ultimately are borne by the firm. As debt increases, therefore, the value of the firm may decrease.

Michael Jensen has argued, however, that increased levels of debt actually increase firm values by creating a strong incentive for efficient operations. ${ }^{314}$ Jensen reasons as follows:

Debt creation, without retention of the proceeds of the issue, enables managers to effectively bond their promise to pay out future cash flows. Thus, debt can be an effective substitute for dividends. ... By issuing debt in exchange for stock, managers are bonding their promise to pay out future cash flows in a way that cannot be accomplished by simple dividend increases. In doing so, they give shareholder recipients of the debt the right to take the firm into bankruptcy court if they do not maintain their promise to

311. See JAMES C. VAN HoRnE, FinanCial MANAGEMENT AND POlicy 276-77 (9th ed. 1992).

312. Id. at 284 " With perfect capital markets, zero bankruptcy costs are assumed. If the firm goes bankrupt, assets presumably can be sold at their economic values with no liquidating or legal costs involved.").

313. Id. at 293-94.

314. Michael C. Jensen, Agency Costs of Free Cash Flow, Corporate Finance, and Takeovers, 76 AM. ECON. REV. 323 (1986). 
make the interest and principle payments. Thus debt reduces the agency costs of free cash flow by reducing the cash flow available for spending at the discretion of managers. These control effects of debt are a potential determinant of capital structure. ${ }^{315}$

The effects of the tax shield, bankruptcy costs, and agency costs on the value of the firm are sufficiently complicated that an evaluation of whether a firm has an optimal capital structure is impossible to accomplish with certainty. Apart from periodic reports of reductions in Kmart's bond ratings, ${ }^{316}$ Kmart's debt levels did not receive much attention from the financial press during Antonini's reign. Shortly after Antonini's ouster, however, Kmart was mentioned as a candidate for bankruptcy, ${ }^{317}$ suggesting that the incentive effects of debt described by Jensen probably were exerting some force on Antonini.

This inference is bolstered by an examination of Kmart's financial statements. As of January 25, 1995, Kmart had long-term debt in excess of $\$ 3.7$ billion, ${ }^{318}$ a long-term debt/equity ratio of $.63,{ }^{319}$ and a times interest earned ratio of $3.06 .^{320}$ By way of comparison, as

315. Id. at 324.

316. See supra notes $84-86$ and accompanying text.

317. See, e.g., Financial World Still Waiting for Kmart's Big Turnaround, MorNing NEwS TRIB. (Tacoma, Wash.), Oct. 17, 1995, at E5 (noting "rampant speculation of bankruptcy"); Kmart's Stock Falls to a 13-Year Nadir; SEC Filing Is Cited, WALL ST. J., Dec. 18, 1995, at B6 (blaming 15\% drop in Kmart's stock on concerns over an SEC filing in which Kmart outlined "potential problems the company could face with its debt and in paying off suppliers and factors"); Phyllis Plitch, Whitman Put Contract Seeks to Lessen Risk If Kmart Files Under Chapter 11, WALL ST. J., Dec. 7, 1995, at A9 (reporting that certain creditors of Kmart purchased a right to put accounts receivables if Kmart declares bankruptcy); Linda Sandler, Kmart Should Consider a Chapter 11 Filing As Best Vehicle for Drastic Changes, Some Say, WAIL ST. J., Oct. 16, 1995, at C2 (reporting on analysts' suggestions that Kmart consider declaring bankruptcy as a solution to some of its problems).

318. Includes long-term debt of $\$ 2.011$ billion and capital lease obligations of $\$ 1.777$ billion. 1994 ANNUAL REPORT, supra note 43, at 32. The long-term debt includes medium-term notes ( $\$ 680$ million), mortgages ( $\$ 315$ million), and the following debt securities: $121 / 8 \%$ notes due 1995 ( $\$ 150$ million), $81 / 8 \%$ notes due 2006 ( $\$ 199$ million), $81 / 4 \%$ notes due 2022 ( $\$ 99$ million); $121 / 2 \%$ debentures due 2005 ( $\$ 100$ million), $83 / 8 \%$ debentures due 2022 ( $\$ 100$ million); $73 / 4 \%$ debentures due 2012 ( $\$ 198$ million), and $7.95 \%$ debentures due 2023 (\$299 million). Id. at 45.

319. Kmart had total long-term debt (including capitalized leases) of $\$ 3.788$ billion and total shareholders' equity of $\$ 6.032$ billion. Id. at 32 . All of the ratios in this section are computed following BREALEY \& MYERS, supra note 146, at 677-78.

320. Kmart had earnings before interest and taxes of $\$ 788$ million, 1994 ANNUAL REPORT, supra note 43 , at 31 , depreciation expense of $\$ 724$ million, id. at 33 , and interest expense of $\$ 494$ million. Id. at 31. 
of January 31, 1995, Wal-Mart had long-term debt of over $\$ 9.7$ billion, ${ }^{321}$ a long-term debt/equity ratio of $.76,{ }^{322}$ and a times interest earned ratio of $8.55^{323}$ Although these ratios provide only a rough picture of Kmart's financial position, it is apparent that despite Kmart's lower absolute levels of debt, its ability to meet its obligations was less certain than Wal-Mart's (a fact attributable to Wal-Mart's superior earnings).

No one contends that debt should be the only method of providing incentives to management, but in combination with other external and internal constraints on managerial behavior, debt policy may play an important role in the corporate governance system. In the case of Kmart, debt was present in sufficient quantities to allow an inference that it provided management with some positive incentives for efficiency. As with so many other components of the corporate governance system, however, the incentive effects of debt are unable to cure managerial incompetence.

\section{Shareholders}

Shareholders in public corporations have long been characterized by their passivity and have not been expected to play more than a reactive role in corporate governance. ${ }^{324}$ The recent rise of institutional investor activism has provided an opportunity to reconsider that view of shareholders. Kmart's shareholders played a particularly active role in corporate governance. With respect to Kmart's corporate governance problem, however, the shareholders were constrained somewhat by their inability to fire Antonini directly. They did the next closest thing, threatening to fire the directors if

321. Includes long-term debt of $\$ 7.871$ billion and capital lease obligations of $\$ 1.838$ billion. WAL-MART STORES INC., 1994 ANNUAL REPORT 18.

322. Wal-Mart had total long-term debt (including capitalized leases) of $\$ 9.709$ billion and total shareholders' equity of $\$ 12.726$ billion. Id.

323. Wal-Mart had earnings before interest and taxes of $\$ 4.968$ billion, id. at 17 , depreciation expense of $\$ 1.070$ billion, $i d$. at 20 , and interest expense of $\$ 706$ million, $i d$. at 17.

324. See, e.g., BERLE \& MEANS, supra note 116, at 64 ("[T]he position of ownership has changed from that of an active to that of a passive agent."); EASTERBROOK \& FISCHEL, supra note 90 , at 83 ("Given the combination of a collective action problem and easy exit through the stock market, the rational strategy for most dissatisfied shareholders is to sell rather than incur costs in attempting to bring about change through votes."); $c f$. Bratton \& McCahery, supra note 90 , at 1865 ("It follows from assertions by Berle and Means that shareholders lack any effective means to monitor the firm themselves, that no adjustment of shareholder incentives will cure the problem, and that therefore the state must intervene to pick up the slack by imposing mandatory rules."). 
they did not do the job. ${ }^{325}$ Three aspects of shareholder participation in corporate governance are discussed below: shareholder voting, shareholder suits, and institutional investor activism.

\section{a. Shareholder Voting}

State rules governing shareholder voting in corporations are quite simple ${ }^{326}$ and have remained largely unchanged since the passage of federal securities laws, ${ }^{327}$ although they underwent dramatic changes during the rise of the modern business corporation. ${ }^{328}$ Within the broad grant of authority under Section 14(a) of the Securities Exchange Act of $1934,{ }^{329}$ the SEC has created detailed rules man-

325. Melissa George, Kmart's Antonini Resigns from President, CEO Posts, DES MOINES REG., Mar. 22, 1995, at 10S ("Perkins . . . said Kmart had been informed that at least one large investor was interested in mounting a campaign against the company before its 1995 annual meeting.").

326. See DEL. CODE ANN. tit. 8, §§ 211-31 (1974 \& Supp. 1994); MODEL BUSINESS CORP. ACT $\$ \$ 7.20-7.28$ (1984).

327. The prominent exception to this statement is cumulative voting, which has remained an active source of reform throughout. See Gordon, supra note 201, at 142-46.

328. For example, the right to vote by proxy did not exist at common law unless granted by special authorization, usually by charter provision. See Samuel Williston, The History of the Law of Business Corporations before 1800, in SELECT ESSAYS IN ANGLOAMERICAN LEGAL HISTORY 226 (1909). In the mid-1800s, state general incorporation laws granted shareholders the right to vote by proxy. Leonard $\mathrm{H}$. Axe, Corporate Proxies, $41 \mathrm{MiCH}$. L. REV. 38, 46-48 (1942). Another example of the evolution of state voting rules is the "one share, one vote" rule. Early in the 19th century, state corporation laws provided that each shareholder was entitled to one vote, regardless of the number of shares owned. Joel Seligman, Equal Protection in Shareholder Voting Rights: The One Common Share, One Vote Controversy, 54 GEO. WASH. L. REv. 687, 693 (1986). By the end of the 19th century, most statutes provided for one vote per share of common stock. Id. Early in this century, common stock and preferred stock typically had equal voting rights. Id. at 693-94. Only after 1903 did companies begin to restrict voting rights of certain classes of shares. Id. at 694 . Other developments in state voting rules also emerged. For example, some states authorized the use of voting trusts. See, e.g., S.F. Fowler, Some Features of Tennessee's 1929 Corporation Act, 8 TENN. L. REV. 3, 7 (1929); Harvey Hoshour, The Minnesota Business Corporation Act, 17 MINN. L. REV. 689, 700-02 (1933); Leon D. Metzger, The Business Corporation Law, 38 DICK. L. REv. 77, 91 (1934). Other rules allowed a reduction of supermajority shareholder approval requirements for many actions to a majority. See, e.g., Henry W. Ballantine, Recent Legislation: Changes in the California Corporation Laws (1929), 17 CAL. L. REV. 529, 533 (1929). Some statutes allowed for unanimous written consent of shareholders in lieu of a meeting. See, e.g., Henry W. Ballantine, $A$ Critical Survey of the Illinois Business Corporation Act, 1 U. CHI. L. REV. 357, 387 (1934). Finally, others gave corporations the right to confer voting power upon bondholders. See, e.g., Paul J. Bickel, Ohio's New Corporation Law, 15 GEO. L.J. 409,423 (1927). For an excellent description of changes in the Massachusetts and Illinois statutes from 1886 to 1936, see E. Merrick Dodd, Jr., Statutory Developments in Business Corporation Law, 1886-1936, 50 HARV. L. REV. 27 (1936)).

329. 15 U.S.C. \& 78 n(a) (1994). The SEC is authorized to promulgate rules governing the solicitation of proxies "in the public interest and for the protection of investors." Id. 
dating certain disclosure and procedures in the solicitation of proxies. ${ }^{330}$ Since the adoption of federal proxy rules, controversies regarding shareholder voting tend to be played out on the federal level. ${ }^{331}$

The ability of institutional investors to force A.ntonini's ouster was intimately tied to several shareholder voting rules: (1) the state rule that forced a vote on the targeted stock proposal; ${ }^{332}$ (2) the state rule that required Kmart to obtain the affirmative vote of a majority of the outstanding shares (rather than a majority of the votes cast) to amend its charter to provide for the issuance of targeted stock, ${ }^{333}$ (3) the state rule mandating that shareholders vote to elect directors, which allowed shareholders to pressure directors into

330. 17 C.F.R. $\$ \$ 240.14 a-1$ to $240.14 c-101$ (1995).

331. The most notable recent controversy involved the comprehensive review and less comprehensive amendment to the proxy rules adopted in 1992. See Regulation of Communications Among Shareholders, Exchange Act Release No. 31,326, 57 Fed. Reg. 48, 276 (1992). For a description of the amendments, see Jill E. Fisch, From Legitimacy to Logic: Reconstructing Proxy Regulation, 46 VAND. L. REV. 1129, 1165-70 (1993). During the late 1980s, a controversy erupted with respect to a proposal by the New York Stock Exchange (NYSE) to allow the issuance of "unbundled stock units," which consist of three new securities from existing shares of common stock: a bond, a preferred share, and an equity appreciation certificate. After opposition from the California Public Employees' Retirement System (CalPERS) and other institutional investors on grounds that the proposal violated Rule 19c-4, the NYSE dropped the proposal. See Sixth Annual Review of Developments in Business Financing, 45 Bus. LAW. 441, $446-49$ (1989) (describing unbundled stock units); Shareholder Groups Oppose Exemption for Unbundled Stock Unit Voting Rights, 21 Sec. Reg. \& L. Rep. (BNA) No. 8, at 304 (Feb. 24, 1989). A controversy similar to the one surrounding unbundled stock units occurred in 1986 after the NYSE proposed a rule permitting dual-class common stock. For a sampling of the many articles written on this controversy, see Daniel R. Fischel, Organized Exchanges and the Regulation of Dual Class Common Stock, 54 U. CHI. L. REV. 119 (1987); Gilson, supra note 202; and Jeffrey N. Gordon, Ties That Bond: Dual Class Common Stock and the Problem of Shareholder Choice, 76 CAL. L. REV. 1 (1988). In an attempt to solve the dual-class common stock controversy, the SEC adopted Rule 19c-4, which was later struck down in Business Roundtable v. SEC, 905 F.2d 406, 407 (D.C. Cir. 1990). The New York Stock Exchange, the American Stock Exchange, and NASDAQ resolved the controversy in early 1995 by adopting a uniform voting right listing standard. For a description of the standard, see Robert Todd Lang, Shareholder Voting Rights-The New Uniform Listing Standard, INSIGHTS, Feb. 1995, at 4. A constant source of controversy under the proxy rules has been Rule 14a-8, the shareholder proposal rule. For a recent discussion of the shareholder proposal rule, see Alan R. Palmiter, The Shareholder Proposal Rule: A Failed Experiment in Merit Regulation, 45 ALA. L. REV. 879 (1994).

332. MICH. COMP. LAwS ANN. $\$ 450.1611$ (West 1995) (requiring shareholder approval of charter amendments).

333. Id. (requiring "the affirmative vote of a majority of the outstanding shares" for approval of charter amendments). 
requesting Antonini's resignation; ${ }^{334}$ and (4) the federal proxy rules that laid the ground rules for the solicitation of proxies with respect to the targeted stock proposal. ${ }^{335}$

These voting rules not only mandated a shareholder vote on the targeted stock proposal, which was as much a decision of corporate business strategy as an issue of capital structure, but the rules also determined the ground rules of the confrontation and (by dictating the number of shareholder votes necessary for approval) the outcome of the vote. In addition, these voting rules allowed shareholders to exert pressure for change on the board of directors. Still, with respect to Kmart's corporate governance problem, shareholder voting rules have at best an indirect connection. As noted above, shareholders are not empowered to replace incompetent officers, but voting rules enable shareholders to threaten to replace directors who fail to replace incompetent officers. Whether such indirect power over officers is meaningful depends on whether shareholders can make the threat against directors credible. In the case of Kmart, ownership was sufficiently concentrated and shareholders were sufficiently determined to pose a real threat, as exhibited by their victory against the targeted stock proposal.

\section{b. Shareholder Suits}

Roberta Romano has described the role of shareholder suits within the corporate governance system as follows: "Shareholder litigation is accorded an important stopgap role in corporate law. Liability rules are thought to be called into play when the primary governance mechanisms ... fail in their monitoring efforts but the misconduct is not of sufficient magnitude to make a control change worthwhile." ${ }^{\text {"336 }}$ Although less dramatic than the market for corporate control, shareholder suits also are considered a remedy to be used only in extreme circumstances, and their major impact may be in the threat rather than the execution.

334. Id. $\$ 450.1402$ (West 1995) (requiring an annual meeting of shareholders for the election of directors); $i d$. $\S 450.101$ (West 1995) (proscribing the adoption of bylaws delegating to the directors the right to elect or dismiss directors).

335. 17 C.F.R. $\$ \$ 240.14$ a to $240.14 c-101$ (1995).

336. Roberta Romano, The Shareholder Suit: Litigation Without Foundation?, 7 J.L. ECON. \& ORGANIZATION 55, 55 (1991); cf. Bratton \& McCahery, supra note 90, at 1865-66 (referring to shareholder suits as the "fiduciary" strategy for solving the problem of agency costs and noting that, under this strategy, "process rules that provide entrepreneurial lawyers with financial incentives to enforce fiduciary norms address the shareholders' collective action problem"). 
Shareholder suits might serve to increase the value of a corporation in two ways: (1) providing compensation to shareholders (in the case of direct actions) or the corporation (in the case of derivative actions) for wrongs committed by corporate officers and directors; and (2) deterring corporate officers and directors from wrongdoing. ${ }^{337}$ Whether shareholder suits actually serve either of these functions has been the subject of extensive debate. ${ }^{338}$ The empirical evidence suggests that compensation from shareholders suits is minimal, and that attorneys are the primary beneficiaries. ${ }^{339}$ In addition, Roberta Romano has found little empirical support for the use of shareholder suits as a monitoring device. ${ }^{340}$ In a recent article, Reinier Kraakman, Hyun Park, and Steven Shavell suggest that shareholder suits are not intrinsically flawed, but suffer from the fact that a shareholder's incentives to bring suit may diverge from the interests of the corporation or other shareholders. ${ }^{341}$

Kmart was not the subject of a major shareholder suit during Antonini's tenure, although some board members reportedly were concerned about the prospect of being sued just prior to Antonini's resignation. Even if shareholder suits work as their proponents hope, they would have done little to solve Kmart's corporate governance problem because, although shareholders may be able to sustain a

337. Reinier Kraakman et al., When Are Shareholder Suits in Shareholder Interests?, 82 GEO. L.J. 1733, 1736 (1994) ("[A] derivative suit increases corporate value in two circumstances: if the prospect of suit deters misconduct or, alternatively, if the suit itself yields a positive recovery net of all costs that the corporation must bear as a consequence of suit.").

338. See, e.g., Janet C. Alexander, Do the Merits Matter? A Study of Settlements in Securities Class Actions, 43 STAN. L. REV. 497 (1991); John C. Coffee, Jr., The Regulation of Entrepreneurial Litigation: Balancing Fairness and Efficiency in the Large Class Action, 54 U. CHI. L. REV. 877 (1987); John C. Coffee, Jr., Understanding the Plaintiff's Attorney: The Implications of Economic Theory for Private Enforcement of Law Through Class and Derivative Actions, 86 COLUM. L. REV. 669 (1986); John C. Coffee, Jr., The Unfaithful Champion: The Plaintiff as Monitor in Shareholder Litigation, LAW \& CONTEMP. PROBS., Summer 1985, at 5; Daniel R. Fischel \& Michael Bradley, The Role of Liability Rules and the Derivative Suit in Corporate Law: A Theoretical and Empirical Analysis, 71 CORNELL L. REV. 261 (1986); Kraakman et al., supra note 337; Roberta Romano, Corporate Governance in the Aftermath of the Insurance Crisis, 39 EMORY L.J. 1155 (1990); Romano, supra note 334 .

339. Romano, supra note 336 , at 84.

340. Id. at 85; see also Fischel \& Bradley, supra note 338, at 277-83 (concluding that derivative suits are not an important monitoring device because they lead to only slight market reactions to court decisions).

341. Krakman et al., supra note 337, at 1736. 
claim for gross incompetence as a breach of the duty of care, success on such claims is exceedingly rare. ${ }^{342}$

\section{c. Institutional Investor Activism}

The increasing power of institutional investors in corporate governance in the United States has been well chronicled. ${ }^{343}$ Many commentators have expressed optimism that the concentration of ownership in the hands of institutional investors would allow them to overcome the collective action problems that exist where there are many individual investors, thus improving the monitoring of corporate managers. ${ }^{344}$ Others are skeptical. ${ }^{345}$ With seemingly unintentional understatement, John Matheson and Brent Olson recently concluded, "Apparently, no consensus has emerged about the proper role of institutional shareholders in modern corporate governance. ${ }^{.346}$

As recently as 1991, Ronald Gilson and Reinier Kraakman identified only three ways in which institutional investors had become active in corporate governance: (1) by protecting "the marlket for corporate control by seeking to block or dismantle takeover defenses erected by portfolio companies without shareholder approval"; (2) by urging "the creation of shareholder advisory committees"; and (3) by

342. Two notable exceptions are Smith v. Van Gorkom, 488 A.2d 858, 870-93 (Del. 1985), and Francis v. United Jersey Bank, 432 A.2d 814, 817-29 (1981).

343. For an excellent examination of the data regarding the growing presence of institutional investors, see Coffee, supra note 232, at 1329. See also Bratton \& McCahery, supra note 90, at 1867 (arguing that institutional investor activism is a "third strategy"-in addition to enforcing fiduciary rules through shareholder suits and market constraints-for dealing with the problem of agency costs).

344. See, e.g., Bernard S. Black, Agents Watching Agents: The Promise of Institutional Investor Voice, 39 UCLA L. REV. 811, 813 (1992); Bernard S. Black, The Value of Institutional Investor Monitoring: The Empirical Evidence, 39 UCLA L. REV. 895, 917-27 (1992) [hereinafter, Black, Monitoring]; Bratton \& McCahery, supra note 90, at 1906-10; Alfred F. Conard, Beyond Managerialism: Investor Capitalism?, 22 U. MICH. J.L. REFORM 117, 131-39 (1988); George W. Dent, Jr., Toward Unifying Ownership and Control in the Public Corporation, 1989 WIS. L. REV. 881, 923-24; Ronald J. Gilson \& Reinier Kraakman, Investment Companies as Guardian Shareholders: The Place of the MSIC in the Corporate Governance Debate, 45 STAN. L. REV. 985, 990-91 (1993); Gilson \& Kraakman, supra note 227, at 883-92; John H. Matheson \& Brent A. Olson, Corporate Cooperation, Relationship Management, and the Trialogical Imperative for Corporate Law, 78 MINN. L. REV. 1443, 1480-91 (1994); Pound, supra note 191, at 1041-46.

345. See, e.g., Stephen M. Bainbridge, The Politics of Corporate Governance, 18 HARV. J.L. \& PUB. POL'Y 671, 694-99 (1995); Bainbridge, supra note 247, at 1054 n.108; Helen Garten, Institutional Investors and the New Financial Order, 44 RUTGERs L. REV. 585, 63031 (1992); Edward B. Rock, The Logic and (Uncertain) Significance of Institutional Shareholder Activism, 79 GEO. L.J. 445, $472-76$ (1991).

346. Matheson \& Olson, supra note 344, at 1465. 
seeking "direct input into the selection of outside directors." 347 As noted, since that time, institutional investors appear to have become more active in corporate governance. ${ }^{348}$ Kmart is a case in point: SWIB and other institutional investors pressured the board to fire Antonini. Such activism by institutional investors is a relatively new phenomenon, but it seems to be becoming more common. ${ }^{349}$

Much scholarship relating to the role of institutional investors in corporate governance addresses whether institutional investors are able to overcome the collective action problem-that is, whether the expected benefits of action outweigh the expected costs. ${ }^{350} \mathrm{Al}-$ though a single institutional investor in the United States is unlikely to hold more than a small percentage of the outstanding shares of any corporation, and thus will receive only a small percentage of any gains from activism while incurring all or a large share of the costs, recent levels of participation in corporate governance by institutions suggest that they will participate in corporate governance, at least when they can obtain economies of scale (such as when they propose the removal of antitakeover provisions to multiple firms), ${ }^{351}$ or when, as in $\mathrm{Kmart}$, investors perceive a crisis that is not being addressed by the directors or officers of the corporation.

347. Gilson \& Kraakman, supra note 227, at 868.

348. But see Jill E. Fisch, Relationship Investing: Will It Happen? Will It Work?, 55 OHIO ST. L.J. 1009, 1029-34 (1994) (arguing that most institutional investors have not progressed beyond reading proxy statements and exercising their right to vote).

349. See, e.g., Alison L. Cowan, Borden's Board Ousts Chief to Calm Investors, N.Y. TIMES, Dec. 10, 1993, at D1 (stating that directors ousted Anthony D'Amato from his position as Chairman and CEO of Borden); Kenneth N. Gilpin, Big Investor Talked, Grace Listened, N.Y. TIMES, Apr. 10, 1995, at D1, D2 (reporting that Chairman J. Peter Grace, Jr. had been forced from post at W.R. Grace); Del Jones, CEOs Feel the Power of Institutions: Big Investors Take a More Activist Role, USA TODAY, Aug. 9, 1993, at B1 (describing the role of institutional investors in ousting CEOs at General Motors, Westinghouse, American Express, IBM, and Eastman Kodak).

350. Commentators have suggested various ways in which those costs and benefits are likely to be calculated. See, e.g., Coffee, supra note 232, at 1287 (observing that long-term investing may require investors to sacrifice liquidity); Fisch, supra note 348, at 1029-34 (arguing that institutional investors will not engage in "relationship investing" unless they are allowed to obtain special benefits); Gordon, supra note 201, at $126 \mathrm{n} .5$ (describing the high costs of "exit" by shareholders who own large blocks of stock and the resulting attractiveness of participation in corporate governance as an option to exiting); Robert C. Pozen, Institutional Investors: The Reluctant Activists, HARV. BUS. REV., Jan.-Feb. 1994, at 140 (general counsel and a managing director of Fidelity Investments argue that although institutional investors do influence the way companies are run, they are not interested in the day-to-day management of any portfolio company and will become active only if the expected costs of a course of action are less than the expected benefits).

351. See Bernard S. Black, Shareholder Passivity Reexamined, 89 MicH. L. REV. 520 , 580-84 (1990). 
With regard to the problem of managerial incompetence, economies of scale are largely inapplicable. Economies of scale in institutional investor activism arise when an institution "offers the same proposal at a number of companies."352 For example, an institution might propose the removal of antitakeover devices at every firm in which it owns stock without investing resources to investigate the details of each firm's devices. This is possible if the institution concludes that no firm should be insulated from the threat of takeover. Decisions regarding the quality of managerial performance, on the other hand, require individual attention because each business is unique. Unlike the situation in which an institution opposes all antitakeover devices, it is not rational to oppose all incumbent managers, and the process of deciding which managers to support and which to oppose is time consuming and expensive.

The type of activism most likely to address managerial incompetence, therefore, is what Mark Roe has described as "crisis monitoring." This is a type of monitoring that "requires neither that the monitors manage day to day nor that they even understand the industry well; they must only be able to identify poor results and evaluate whether those results were due to poor management."353 Even crisis monitoring may be prohibitively expensive, however, as noted recently by Stephen Bainbridge:

Because it is impossible to predict ex ante which corporations are likely to experience [serious long-term] problems, activist institutions will be obliged to monitor all of their portfolio firms. At the bare minimum, activist institutions will be obliged to closely scrutinize corporate disclosures for signs of impending trouble. The length and complexity of corporate disclosure documents makes this an expensive proposition both in terms of time invested and the need for specialized expertise. More important, because corporate disclosures rarely give one a full picture of the corporation's prospects, additional and more costly monitoring mechanisms must be established.

Monitoring costs are only the beginning, of course. Once the problem firm is identified, the activist institution must take steps to address the problem. In some cases, it may suffice for the activist institution to raise the problem with management. Less tractable problems will necessitate 
more extreme remedial measures, such as removal of the incumbent board of directors. ${ }^{354}$

One way of reducing the monitoring costs identified by Bainbridge is to create a third-party monitoring organization, like the Council of Institutional Investors (CII), to serve multiple institutional investors. ${ }^{355}$ The CII "provides a forum for funds to share information and to jointly monitor corporate performance, executive pay and governance related issues." investors is to create a list of companies that have been performing poorly in one or more of the three areas just named. Tim Opler and Jonathan Sokobin recently found that among listed companies, acquisition rates decline, divestiture rates go up significantly and ... top management change slows down (if anything). We interpret this as evidence that institutional activism gets some of its results by forcing change, but not necessarily by removing existing management. Despite well-publicized cases at American Express, Kodak, IBM and General Motors where activism was associated with a change in CEO, most firms on the $1993 \mathrm{CII}$ focus did not experience such a change. 357

Kmart appeared on the $1993 \mathrm{CII}$ list, ${ }^{358}$ and may be added to those companies where activism has been associated with a change in the CEO. Nevertheless, as noted by Opler and Sokobin, active participation by institutional investors like those in Kmart remains episodic.

Recently, legal scholars have suggested that the gap between ownership and control described by Berle and Means is not inherent in modern corporations and that institutional investor activism would become more common if institutions were allowed to narrow that gap by acquiring larger stakes in companies. ${ }^{359}$ These claims have been reinforced by comparing institutional investors in the United States with those in Japan, Germany, and other countries. ${ }^{360}$ The focus of

354. Bainbridge, supra note 345 , at 694 .

355. See Tim C. Opler \& Jonathan Sokobin, Does Coordinated Institutional Activism Work? An Analysis of the Activities of the Council of Institutional Investors, available on the Internet at http://www.cob.ohio-state.edu/dept/fin/faculty/opler/ciiabs.htm.

356. Id. at 4-5.

357. Id. at 14-15.

358. Id. at 28.

359. See, e.g., Black, supra note 351; Mark J. Roe, A Political Theory of American Corporate Finance, 91 CoLUM. L. REV. 10, 53-65 (1991).

360. For recent examples, see Theodor Baums, Corporate Governance in Germany: The Role of the Banks, 40 AM. J. COMP. L. 503 (1992); Bernard S. Black \& John C. 
these comparisons has been ownership concentration; in countries other than the United States, where institutional investors (particularly banks) tend to obtain much higher concentrations of stock ownership, institutional investors often have much closer relationships with managers than is typical in the United States. The primary importance of this strain of scholarship has been the claim that the separation of ownership and control is not the inevitable outcome of an evolution to efficiency, but is historically contingent, and that politics, not economics, has been the primary force behind ownership structure. $^{361}$ That descriptive thesis, however, has normative implications. Bernard Black and John Coffee contend that the "principal policy implication of this new political theory of the American corporation is obvious: deregulate in order to lower the costs of coordination among shareholders."362 Mark Roe states: "[S]ince no corporate governance form seems obviously superior for all firms at all times, we ought to allow competition among governance systems." 363

These insights, although important and potentially far-reaching, are not directly relevant to the discussion here, which concerns the rules that govern institutional investor participation in corporate governance when shareholders, although potentially powerful, are more widely dispersed than investors in many other countries. In the deregulated world promoted by Black, Coffee, Roe, and others, firms with concentrated ownership will likely become "relational investors"364 or will develop "consensus" methods of decisionmaking like those described by Kenneth Arrow. ${ }^{365}$ Arrow defines "consensus" decisionmaking as "any reasonable and accepted means of aggregating

Coffee, Jr., Hail Britannia?: Institutional Investor Behavior Under Limited Regulation, 92 MICH. L. REV. 1997 (1994); Richard M. Buxbaum, Institutional Owners and Corporate Managers: A Comparative Perspective, 57 BROOK. L. REV. 1 (1991); Ronald J. Gilson \& Reinier Kraakman, Investment Companies as Guardian Shareholders: The Place of the MSIC in the Corporate Governance Debate, 45 STAN. L. REV. 985 (1993); Gilson \& Roe, supra note 200; Friedrich K. Kubler, Institutional Owners and Corporate Managers: $A$ German Dilemma, 57 BROOK. L. REV. 97 (1991); Roe, supra note 202.

361. The most complete statement of this position is found in ROE, supra note 353. For critiques of Roe's position, see Bainbridge, supra note 345; Mark Ramseyer, Columbian Cartel Launches Bid for Japanese Firms, 102 YALE L.J. 2005 (1993); Roberta Romano, A Cautionary Note on Drawing Lessons From Comparative Corporate Law, 102 YALE L.J. 2021 (1993).

362. Black \& Coffee, supra note 360, at 1999.

363. ROE, supra note 353 , at 238.

364. For a discussion of relational investing, see Ayres \& Cramton, supra note 15; Bratton \& McCahery, supra note 90.

365. KENNETH J. ARROW, THE LIMITS OF ORgANIZATION (1974). 
individual interests, ${ }^{, 366}$ and argues that the consensus model is an appropriate alternative to "authority" (i.e., centralized decisionmaking) only when the members of the organization have identical interests and identical information. ${ }^{367}$ Under those circumstances, "each member would correctly perceive the best decision according to his interests, and since the interests are in common, they would all agree on the decision. ${ }^{\prime 368}$

Shareholders in traditional public corporations in the United States do not fit well within the consensus model, ${ }^{369}$ which is best suited to small groups where information may be exchanged cheaply to obtain the requisite identity of information. Although the experiences of Germany, Japan, Britain, and other countries suggest that consensus models are possible or even desirable in the corporate context, consensus governance is not yet the norm in the United States, and even proponents of institutional investor activism concede that such a system is "largely aspirational."

Given the current structure of share ownership in the United States, serious questions remain about the value of institutional investor participation in solving the problem of managerial incompetence. Scholars have identified several potential pitfalls for institutional investor activism: (1) whether institutional investors' short-term investment horizons are amenable to corporate governance; ${ }^{371}$ (2) whether institutional investors have the necessary expertise to participate meaningfully in corporate governance, ${ }^{.72}(3)$ whether institutional investors' interests are representative of other shareholders; ${ }^{373}$ (4) whether conflicts of interest faced by institutional investors preclude their effective participation in

366. Id. at 69.

367. Id.

368. Id.

369. Bainbridge, supra note 345 , at 676 ("The modern public corporation precisely fits Arrow's model of an authority-based decision-making structure.").

370. Bratton \& McCahery, supra note 90 , at 1871.

371. See, e.g., MiCHAEL E. PORTER, THE COMPETITIVE ADVANTAGE OF NATIONS 528 (1990); Lipton \& Rosenblum, supra note 135, at 205-13.

372. See, e.g., John M. Conley \& William M. O'Barr, The Culture of Capital: An Anthropological Investigation of Institutional Investment, 70 N.C. L. REV. 823 (1992); Fisch, supra note 348, at 1037-38; Garten, supra note 345, at 629-30; Comment, Regulations $14 \mathrm{~A}$ and $13 D$ and the Role of Institutional Investors in Corporate Governance, 87 NW. U. L. REV. 376, 406-08 (1992).

373. See, e.g., Coffee, supra note 232, at 1328-36; Fisch, supra note 348, at 1038-47; Edward B. Rock, Controlling the Dark Side of Relational Investing, 15 CARDOZO L. REV. 987, 989 (1994); Rock, supra note 345, at 466-78. 
corporate governance, ${ }^{374}$ and (5) whether institutional investors might be prone to overreaching, crossing the line between monitoring and managing. ${ }^{375}$ In addition, studies of the value of institutional investor activism have returned mixed results. ${ }^{376}$

The institutional investors in Kmart were instrumental in Kmart's decision to divest itself of the specialty retailing subsidiaries and in the board's decision to ask for Antonini's resignation. With respect to Kmart's corporate governance problem, therefore, it is clear that active institutional investors had a significant impact, despite their inability to address any perceived problems directly. The more difficult problem, discussed below, is whether institutional investors should have such an impact.

\section{Two FUNDAMENTAL LESSONS FROM KMART}

Over a decade ago, Melvin Eisenberg suggested that the problem of managerial incompetence "may well be ... the most important contemporary problem concerning managerial accountability."377 As

374. See, e.g., Jayne W. Barnard, Institutional Investors and the New Corporate Governance, 69 N.C. L. REV. 1135, 1141 n.39 (1991); Roberta Romano, Public Pension Fund Activism in Corporate Governance Reconsidered, 93 COLUM. L. REV. 795 (1993).

375. Bainbridge, supra note 345 , at 717-23.

376. Two relatively early studies tentatively concluded that institutional investor activism increased firm values. See Fisch, supra note 348, at 1035 (citing Lilli A. Gordon \& John Pound, Active Investing in the U.S. Equity Market: Past Performance and Future Prospects, Report for the California Public Employees' Retirement System 44 (1993)) (activism is "capable of leading to significant value increases"); Black, Monitoring, supra note 376, at 925 (institutional investors "may be able to add value through monitoring"). With respect to the Black article, compare Cox, supra note 242, at 1262 ("Despite the paucity of empirical data upon which he draws and his own cautious observation that fund managers lack the time and prior experience to micro-manage their portfolio companies, Professor Black nevertheless concludes, somewhat wistfully, with the conviction that monitoring is not intrinsically more difficult than trading."). Some more recent studies find that institutional investor activism has little effect. See Stuart L. Gillan \& Laura T. Starks, Relationship Investing and Shareholder Activism by Institutional Investors (manuscript); Kose John \& April Klein, Shareholders Proposals and Corporate Governance (manuscript); Jonathan M. Karpoff et al., Corporate Governance and Shareholder Initiatives: Empirical Evidence (manuscript); Sunil Wahal, Pension Fund Activism and Firm Performance, J. FIN. \& QUANTITATIVE ANALYSIS (forthcoming 1996). Other recent studies find small positive returns from investor activism. Stephen L. Nesbitt, Long-term Rewards from Shareholder Activism: A Study of the "CalPERS Effect", J. APP. CORP. FIN., Winter 1994, at 75; Opler \& Sokobin, supra note 355; Michael P. Smith, Shareholder Activism by Institutional Investors: Evidence from CalPERS, J. FIN. (forthcoming 1996); Deon Strickland et al., A Requiem for the USA: Is Small Shareholder Monitoring Effective, J. FIN. EcoN., February 1996, at 319.

377. Melvin A. Eisenberg, New Modes of Discourse in the Corporate Law Literature, 52 GEO. WASH. L. REV. 582, 590 (1984). 
one of the primary spokesmen for the post-Berle and Means scholars who emphasized legal solutions to the separation of ownership and control, Eisenberg argued that the solution to managerial incompetence lay in creating "a structure that will facilitate an atmosphere of objective internal oversight of, and full information concerning, the top managers' performance, so that the board is in a position to replace top managers who are markedly inefficient, although doing their moral best." $" 378$

Contractarians largely rejected the board of directors as an effective monitoring mechanism, arguing that the solution to managerial incompetence lay ex ante in the screening power of the managerial labor markets and ex post in the power of the market for corporate control to replace any incompetent managers who survived the managerial labor markets. ${ }^{379}$ Indeed, the contractarians appeared to have so much confidence in the power of these markets that when discussing the challenges facing the corporate governance system, they routinely ignored the problem of managerial incompetence or subsumed it into the analysis of managerial abuse. ${ }^{380}$ But as discussed above, the power of managerial labor markets to screen out incompetent managers and the power of takeovers to be a consistent and practical solution to managerial incompetence have proven doubtful. The problem of managerial incompetence, therefore, remains a critical issue for corporate governance scholars.

Among many scholars, hopes for solving the problem of managerial incompetence now rest with active institutional investors. Although the focus of this new scholarship has been on improving the ability of the corporate governance system to replace incompetent managers (reducing type I errors), as discussed above, the corporate governance system also may err by replacing competent managers (type II errors). Structuring legal rules to facilitate the removal of managers by institutional investors has intuitive appeal in the present

378. $I d$.

379. See supra parts II.B.4 and II.B.2, respectively.

380. See, e.g., EASTERBROOK \& FISCHEL, supra note 90 , at 10 (describing agency costs of the separation of ownership and control as diversion of assets, slacking, and unwillingness to take risks); Bainbridge, supra note 247, at $1057 \mathrm{n} .120$ (defining "shirking" to include "behavior ranging from honest mistakes to laziness to culpable self-dealing"); cf. Lipton \& Rosenblum, supra note 135, at 195 ("Proponents of the managerial discipline model tend to view any action taken by managers that conflicts with the wishes of the stockholders as evidence of managerial self-interest .... [and] ignore the possibility that ... the divergence may simply reflect differing perspectives as to the appropriate direction and business plan of the corporation."). 
situation, where shareholders suffer from severe collective action problems, boards are controlled by senior executive officers, and markets are unreliable monitors of managerial incompetence. Even today, however, type II errors may be common, ${ }^{381}$ and if institutional investors became more active in replacing executive officers, type II errors would likely become even more common.

The puzzle thus persists: How can the corporate governance system reduce the total error costs associated with decisions regarding managerial incompetence? When the goal is to reduce total error costs, policy prescriptions must be aimed at improving the ability of the decisionmaking process to generate correct decisions. More specifically, reforms should be aimed at improving the independence of the decisionmaker, the information provided to the decisionmaker, and the incentives of the decisionmaker to make correct decisions. ${ }^{382}$

As illustrated by the foregoing analysis of Kmart, no single corporate governance mechanism yet devised has been able to provide satisfactory independence, information, and incentives. The following discussion draws two fundamental lessons from the analysis of Kmart in an attempt to identify the areas of legal reform most likely to improve the quality of decisions generated by the corporate governance system. The first lesson is that external constraints on managerial behavior will not efficiently solve the problem of managerial incompetence. In the short term, external constraints are limited to providing incentives for good performance and thus allow type I errors. In the long term, an inefficiently managed company may become the target of a takeover or be driven out of business by product markets, but these actions may result in type II errors.

In light of the limited ability of external constraints to solve the problem of managerial incompetence, the best hope for improving the ability of the corporate governance system to solve this problem lies in improving the efficiency of internal constraints. ${ }^{383}$ Since Berle

381. Naveen Khanna and Annette Poulsen compared actions taken by managers of financially distressed firms with more successful firms and concluded that financial distress "is not the result of managers making less competent decisions than their competitors or taking actions that are inconsistent with shareholder wealth maximization." Khanna \& Poulsen, supra note 25, at 938. Previous studies have revealed that managers of firms with poor performance are more likely to be replaced than managers of other firms. See, e.g., Stuart Gilson, Management Turnover and Financial Distress, 25 J. FIN. ECON. 241 (1989); Steven Kaplan \& David Reishus, Outside Directorships and Corporate Performance, $27 \mathrm{~J}$. FIN. ECON. 389 (1990).

382. See supra note 28.

383. In his Presidential Address to the American Finance Association in January 1993, Michael Jensen, who is credited with first conceptualizing the contractarian paradigm, 
and Means, two developments have changed dramatically the ability of internal constraints to address managerial incompetence: corporations have increased the percentage of outside directors on their boards; and (2) institutional investors have acquired larger shares of public corporations and have become more active in internal corporate affairs. The most important contemporary corporate governance issue is how to balance power between independent boards and large institutional investors.

Although substantial experience teaches that concentration of power in the hands of managers does not maximize the value of the firm to shareholders, transferring power to shareholders also has high costs, primarily the destruction of centralized decisionmaking by the board of directors. The second lesson from $\mathrm{Kmart}$ is that institutional investors-even if permitted to participate more directly in decisions regarding managerial incompetence-will not efficiently solve the problem of managerial incompetence. This insight has extensive policy implications for many aspects of the modern corporate governance debate. Section $\mathrm{C}$ discusses policy implications for shareholder involvement in board composition and business policy.

\section{A. Lesson \#1: External Constraints Will Not Efficiently Solve Managerial Incompetence}

In evaluating the ability of the four external constraints discussed above to solve managerial incompetence, it is useful to assume that Antonini was incompetent in the sense that, although he earnestly endeavored to meet shareholder expectations for his performance, he simply was not up to the task. During Antonini's tenure, the external constraints seemed to provide strong incentives for good performance: Kmart stock prices sank; rumors of a takeover of Kmart surfaced; Kmart lost market share to Wal-Mart, Target, and other retailers; and Antonini's compensation suffered. In addition, the directors provided other incentives through Kmart's dividend and debt policies. But these incentives-no matter how strong-could not cause Antonini's replacement.

proclaimed: "[M]aking the internal control systems of corporations work is the major challenge facing economists and management scholars in the 1990s." Jensen, supra note 203 , at 873 . Of course, reformers are not writing on a clean slate. Improving internal controls was the central thrust of post-Berle and Means scholarship, culminating in 1976 in Eisenberg's The Structure of the Corporation: A Legal Analysis. Thus William Bratton's comment: "Corporate law seems to have ended the 1980 s at the same point where it began them-grappling with the problem of excess management power in the Berle and Means corporation.” Bratton, supra note 131, at 182. 
External forces solve managerial incompetence in only two instances: (1) when the market for corporate control directly attacks managerial incompetence by replacing the incompetent manager, and (2) when product markets directly attack managerial incompetence by forcing companies out of business. Both of these solutions to managerial incompetence are effective at replacing managers but are slow and costly responses when compared with action by the board of directors. Again, consider Antonini. Assuming that he was incompetent to manage Kmart, Antonini nevertheless maintained his high office for over seven years before his ouster, and even then neither the market for corporate control nor the product markets were the direct cause of his replacement. ${ }^{384}$

In addition to being slow and costly, both the market for corporate control and product markets may produce substantial type II errors. If the capital markets are not fundamental-value efficient, for example, takeovers may cause the replacement of competent managers because the stock of the companies they manage may be trading at a discount to long-term fundamental value. ${ }^{385}$ Product

384. For another recent and highly publicized example of a CEO who was ousted by a board of directors after severe pressure from external constraints, see Jim Carlton, Apple Ousts Spindler as Its Chief, Puts National Semi CEO at Helm, WALL ST. J., Feb. 2, 1996, at A3 (ouster of Michael Spindler as CEO of Apple Computer, Inc.). For more detailed descriptions of reduced stock prices, fumbled takeover negotiations, lost market share, and other troubles at Apple, see Kathy Rebello et al., The Fall of an American Icon, BUs. Wk., Feb. 5, 1996, at 34; Brent Schlender, Paradise Lost: Apple's Quest for Life After Death, FORTUNE, Feb. 19, 1996, at 64.

385. See Reinier Kraakman, Taking Discounts Seriously: The Implications of "Discounted" Share Prices as an Acquisition Motive, 88 ColuM. L. REV. 891 (1988). Whether capital markets are fundamental-value efficient has important policy consequences for the market for corporate control. As Ronald Gilson and Bernard Black recently noted:

If shareholders are good at valuing public companies, that strengthens the case for a relatively free market in corporate control-for letting shareholders decide whether a target should be sold. Conversely, if shareholders are prone to irrational fads, that strengthens the case for giving the target's board of directors some discretion to resist a takeover proposal that the shareholders would endorse.

GILSON \& BLACK, supra note 157, at 136. This has interesting implications for the debate over corporate charter competition. It has been widely assumed that the adoption of antitakeover statutes in most states, including Delaware, refutes the strong form of the "race to the top" thesis (i.e., that corporate charter competition always produces optimal results). See, e.g., EASTERBROOK \& FISCHEL, supra note 90, at 222; William W. Bratton, Corporate Law's Race to Nowhere in Particular, 44 U. TORONTO L. REV. 401 (1994). If stock prices do not reflect fundamental firm values, however, event studies on the effect of antitakeover statutes on stock prices may not prove that antitakeover statutes are contrary to the long-term interests of shareholders. 
markets, too, may cause type $I I$ errors by punishing companies for past mistakes until they are corrected, and sometimes long thereafter. If a competent manager assumes control of a company in the wake of an incompetent manager, the company may be driven out of business through no fault of the competent manager.

Short of an actual (not merely threatened) takeover or the failure of the business altogether, the most that external constraints can do to solve managerial incompetence is to send signals to shareholders, directors, or potential acquirors that identify a manager's incompetence. Even in this limited role, however, external constraints may be inadequate, depending on the quality of the signals being sent.

In the case of Antonini, for example, although Kmart's board of directors and institutional investors were the direct mechanisms of Antonini's ouster, one inspiration for their action appeared to be the price of Kmart's common stock. ${ }^{386}$ If stock prices fulfilled the hopes of contractarians, stock prices would immediately distill into one convenient measure complex information about managerial performance, and directors would be entitled to rely on stock prices in evaluating performance. As discussed above, however, stock prices may be unable to fulfill their promise. In that case, Antonini's ouster is much more puzzling because it would have been based on a measure that did not accurately reflect his performance.

Other external constraints also may provide inadequate signals of managerial incompetence. Although product markets may be the most reliable indicator of managerial performance over the long term, as noted above, they may punish new managers for past sins. Managerial labor markets undoubtedly screen some incompetent managers at the entry stage, but anecdotal evidence suggests that many incompetent managers thrive despite past failures. ${ }^{387}$

\section{B. Lesson \#2: Institutional Investors Will Not Efficiently Solve Managerial Incompetence}

The most prominent feature of the corporate governance system in Kmart has been the imposing presence of institutional investors. Their dramatic victory in the proxy contest rejecting the targeted stock proposal and their ability to force Antonini's resignation

386. See supra notes 110-12 and accompanying text.

387. See, e.g., Amanda Bennett \& Joann S. Lublin, Teflon Big Shots: Failure Doesn't Always Damage the Careers of Top Executives, WALL ST. J., Mar. 31, 1995, at A1 (describing the careers of William Agee, Frank Lorenzo, Clay Felker, and other executives who continue to find employment despite notable past failures). 
illustrate their willingness to exercise their extensive power. The ability of Kmart's institutional investors to overcome the collective action problem provokes a normative inquiry into the respective roles of shareholders and directors in solving the problem of managerial incompetence: Should institutional investors be encouraged to override the board of directors in matters relating to managerial incompetence, more specifically, in matters of corporate strategy and CEO tenure?

Jeffrey Gordon asked a similar question in regard to Carl Icahn's 1990 struggle to force USX to separate its steel business from its oil business: "[W] USX's shareholders for binding shareholder action?"388 Under current law shareholders have no power over corporate strategy short of launching a control contest or accepting a hostile tender offer. Gordon argued, therefore, that shareholder-manager relations are best characterized by an "absolute delegation rule," which holds that management has "virtually unbounded decisionmaking authority over business matters." tification"390 for this rule is that management has an informational advantage over shareholders, and delegating power over corporate strategy to management increases the value of the firm. ${ }^{391}$ Gordon disputed this justification, arguing that it "does not explain why shareholders would not reserve concurrent power for those occasions, probably rare, when they might wish to assert their business judgment over a particular decision without replacing the board."392 The following sections counter Gordon using both economic and political theory and defend informational advantage as a sufficient justification for the absolute delegation rule. In other words, these sections argue that institutional investors should be discouraged from overriding the board of directors in matters of corporate strategy and CEO tenure to avoid destroying the value of centralized decisionmaking by the

388. Gordon, supra note 30 , at 348.

389. Id. at 351-52.

390. The justification is "standard" not because it has often been employed in deciding the proper level of shareholder participation in decisions regarding corporate strategy, but because it is one of the "familiar . . . explanations for corporate law rules that aggrandize management power vis-a-vis shareholders." Id. at 353.

391. Id. at 353-57. The other standard justification offered by Gordon was that management chooses the state of incorporation, and corporate laws preclude shareholder participation in the formation of corporate strategy so that management can extract governance rents that are significant to them, even if not significant to the firm. Id. at 35758.

392. Id. at 354. 
board of directors. Instead, legal reform should focus on improving director elections and insulating directors from shareholder pressure between elections.

\section{Categories of Shareholder Participation}

Although directors currently are assigned legal responsibility for deciding matters of corporate strategy and CEO tenure, shareholders are responsible for monitoring director performance. ${ }^{393}$ The issue of whether institutional investors should be discouraged from overriding the board of directors in matters of corporate strategy and CEO tenure is at root an issue of the proper scope of shareholder monitoring. In a different article than that in which he made the above observations, ${ }^{394}$ Jeffrey Gordon concluded that institutional investors should avoid participation in policy decisions (which, for purposes of the following discussion, are assumed to include both corporate strategy and CEO tenure decisions ${ }^{395}$ ) because: (1) the need to limit the costs of action will lead to "consensus generic policies"-essentially attempts to obtain economies of scale-that are unlikely to maximize firm value and may simply be wrong for some firms; (2) institutions attempt to develop expertise in stock-picking and marketing, not management, and therefore are not competent to second-guess management on policy matters without costly restructuring; and (3) activism on policy issues will engender political opposition against "monopoly capital" or invite political pressure. ${ }^{396}$

In place of policy participation, Gordon advocates "generic board composition" participation-that is, participation in which shareholders attempt to influence the selection of directors by changing the process or criteria for selection. ${ }^{397}$ More specifically, generic board composition participation might take the form of "press[ing] for director nominations from a pool of professional

393. This is the familiar problem of "Who monitors the monitors?" Fortunately, Armen Alchian and Harold Demsetz solved the problem by showing that the ultimate monitor should be the residual claimant (in the case of corporations, the shareholders), who would have the proper incentives to monitor well. See Armen A. Alchian \& Harold Demsetz, Production, Information Costs, and Economic Organization, 62 AM. ECON. REV. 777,782 (1972). Unfortunately, the collective action problem distorts shareholder incentives. A positive externality of this collective action problem, however, is that it creates an opportunity for much legal and economic scholarship on corporate governance issues.

394. Gordon, supra note 201.

395. See infra note 473.

396. Id. at 129-32.

397. Id. at 133. 
directors" or "press[ing] in a general way for directors of a particular sort, help[ing] develop a pool of potential director nominees, and/or press[ing] for nomination of particular individuals." ${ }^{\text {398 }}$ The central feature of this type of participation is "an institutional role in the selection of directors-whether by their categorical or individual qualifications-that will enhance the directors' sense of accountability to shareholders, creating not just an 'independent' director, but an 'accountable' director."399 Occasionally, Gordon states, shareholders might want to switch to "active board composition" participation-that is, "monitor[ing] the performance of the company and, in the case of poor performance where the board itself has not appropriately intervened, tak [ing] steps to change the board."400

Both types of board composition participation subsume a separate and less intrusive type of participation, which Gordon labels "board structure" participation. ${ }^{401}$ This type of participation attempts to construct a board of directors that is truly independent of the CEO on the assumption that independent boards are more effective monitors than boards comprised of inside directors. ${ }^{402}$ Board structure participation does not require shareholders to acquire substantial firm-specific information; instead, shareholders merely encourage "good governance" reforms. ${ }^{403}$ Similarly, generic board composition participation requires only that the shareholders gather and evaluate information about credentials or backgrounds of potential directors, not that they acquire extensive firm-specific information. Both active board composition and policy participation, on the other hand, may require shareholders to acquire substantial amounts of firm-specific information, depending on the inclination of the particular shareholder. As Gordon explains with respect to the active board composition position: "The institution could measure performance by objective criteria, such as comparative stock price performance in the industry or various accounting measures, for example, return on equity, or it could attempt to engage in more

398. Id.

399. Id.

400. Id. at 134.

401. Id. at 133.

402. Id. Typical activities under this heading would include electing a majority of independent directors, forming nominating and compensation committees made up exclusively of independent directors, and separating the chairman and CEO positions. Id.

403. Id. 
complicated analysis of the firm's business environment and strategies. $" 404$

Gordon views generic and active board composition participation as complementary strategies. Under his preferred regime, generic participation would be employed on an ongoing basis to ensure the election of highly qualified directors; meanwhile, active participation would be used to replace existing directors only when the company has been performing poorly and the directors have failed to act appropriately.

The following discussion supports Gordon's view that institutional investors should not participate in policy decisions of the corporation but should concentrate their efforts on board composition. Although the analysis supports Gordon's primary conclusion, the rationale underlying the present analysis is much different than Gordon's rationale for discouraging policymaking by shareholders. Even if all of Gordon's objections to institutional investor participation in policy matters were overcome, a fundamental objection to such participation would remain - namely, that institutional investor activism diminishes the value of centralized decisionmaking by the board of directors without offsetting benefits.

\section{The Value of Centralized Decisionmaking}

More than two decades ago, in a work generally addressing the limits of organization, Kenneth Arrow provided a useful framework for thinking about the effects of shareholder participation in corporate governance. ${ }^{405}$ Arrow began with the observation that in virtually all organizations, centralized decisionmaking-which Arrow called "authority"-is the rule. ${ }^{406}$ Arrow argued that authority has value to an organization because it coordinates the activities of members of the organization, thus economizing information costs. ${ }^{407}$

404. Id. at 134 .

405. ARROW, supra note 365 .

406. Id. at 63 .

407. Id. at 68; $c f$. Bainbridge, supra note 247 , at 1053 ("[T] he firm can reduce uncertainty and complexity by providing a central decisionmaker having the power to direct how various inputs will be utilized by the firm."). Easterbrook and Fischel argue that centralized decisionmaking in the corporation is a form of division of labor, in which "[t]hose who have wealth can employ it productively even if they are not good managers; those who can manage but lack wealth can hire capital in the market; and the existence of claims that can be traded separately from employment allows investors to diversify their investment interests." EASTERBROOK \& FISCHEL, supra note 90, at 11; see also Eugene F. Fama \& Michael C. Jensen, Separation of Ownership and Control, 26 J.L. \& ECON. 301, 309 (1983) (describing the "nearly complete separation and specialization of decision 
Authority also generates agency costs, as discussed above. ${ }^{408}$ Recognizing that such costs are inherent in authority, Arrow suggested that a necessary counterweight to authority is "responsibility." "409 Decisionmakers may be held responsible in various ways, for example, by subjecting their decisions to an active higher authori$t^{410}$ or to a special authority with limited jurisdiction ${ }^{411}$ or by allowing a higher authority to select the central decisionmaker at specified intervals. ${ }^{412}$ One key to organizational success is striking the proper balance between authority and responsibility. Arrow observes:

To serve its functions, responsibility must be capable of correcting errors but should not be such as to destroy the genuine values of authority. Clearly, a sufficiently strict and continuous organ of responsibility can easily amount to a denial of authority. If every decision of $A$ is to be reviewed by $B$, then all we have really is a shift in the locus of authority from $A$ to $B$ and hence no solution to the original problem.

To maintain the value of authority, it would appear that responsibility must be intermittent. ${ }^{413}$

For purposes of corporate governance, the central authority is the board of directors, which manages or supervises the management of the affairs of the corporation. ${ }^{414}$ In accordance with Gordon's preference for board composition participation, corporate law makes directors responsible to shareholders-at least nominally-primarily through annual elections. Other formal mechanisms for introducing responsibility into the director/shareholder relationship, primarily through policy participation, have been severely limited, in recognition of the fact that challenging authority in this manner imposes

control and residual risk bearing" in large corporations). Regardless of the rationale for centralized decisionmaking, the arguments against supplanting it through shareholder activism hold.

408. See supra text accompanying note 132.

409. ARROW, supra note 365, at 73-76. Arrow's notion of responsibility is analogous to "monitoring" and "bonding" in an agency relationship. Jensen \& Meckling, supra note 129 , at 308.

410. Arrow gives the example of a division manager who is responsible to the president of a corporation. He notes that "[a]t best, of course, devices of this type merely relocate the problem." ARROw, supra note 365 , at 77.

411. Judicial authority is the prime example here. Id.

412. Id.

413. Id. at 77-78.

414. DEL. CODE ANN., tit. 8, § 141(a) (1988); MODEL BusINESS CORP. ACT $\S 8.01$ (1984). 
costs on the corporation. ${ }^{415}$ For example, the business judgment rule restricts the access of shareholders to courts ${ }^{416}$ and the shareholder proposal rule regulates the access of shareholders to the proxy machinery. ${ }^{417}$ Regulating shareholder participation in the context of shareholder litigation or proxy solicitations is relatively simple because both involve a formal legal procedure to which access may be restricted.

Gordon contends, however, that even if the informational advantage of the board of directors justifies a delegation of authority in the ordinary case, that advantage does not justify an "absolute delegation rule" without something more:

Since each shareholder can decide for herself to vote [an] initiative, the absolute delegation rule is desirable for shareholders only if it plausibly protects against the possibility that other shareholders will mistakenly vote for a misbegotten shareholder initiative. Thus, the information argument requires a claim that not only is management

415. For a discussion of these competing values in the corporate context, see Stephen M. Bainbridge, In Defense of the Shareholder Wealth Maximization Norm: A Reply to Professor Green, 50 WASH. \& LEE L. REV. 1423, 1439-40 (1993).

416. With respect to the business judgment rule, see Michael P. Dooley \& Norman Veasey, The Role of the Board in Derivative Litigation: Delaware Law and the Current ALI Proposals Compared, 44 Bus. LAW. 503, 522 (1989):

The power to hold to account is the power to interfere and, ultimately, the power to decide. If stockholders are given too easy access to courts, the effect is to transfer decisionmaking power from the board to the stockholders or, more realistically, to one or few stockholders whose interests may not coincide with those of the larger body of stockholders. By limiting judicial review of board decisions, the business judgment rule preserves the statutory scheme of centralizing authority in the board of directors. In doing so, it also preserves the value of centralized decisionmaking for the stockholders and protects them against unwarranted interference in that process by one of their number. Although it is customary to think of the business judgment rule as protecting directors from stockholders, it ultimately serves the more important function of protecting stockholders from themselves.

See also Waltuch v. Conticommodity Servs., Inc., 833 F. Supp. 302, 306 (S.D.N.Y. 1993) (citing the foregoing favorably); Granada Invs. v. DWG Corp., 823 F. Supp. 448, 455 (N.D. Ohio 1993) (citing the foregoing as support for the proposition that "the business judgment rule [ensures] that the directors, and not the shareholders, manage the corporation, as is required by state statutes").

417. See, e.g., Palmiter, supra note 331, at 886-92 (discussing reasons for limiting shareholder access to proxy machinery); Patrick J. Ryan, Rule 14a-8, Institutional Shareholder Proposals, and Corporate Democracy, 23 GA. L. REV. 97, 113 (1988) (noting that SEC imposed restrictions on the shareholder proposal rule to prevent its abuse); see also George W. Dent, Jr., SEC Rule 14a-8: A Study in Regulatory Failure, 30 N.Y.L. SCH. L. REV. 1, 14-16 (1985) (describing costs of the rule); Susan W. Liebeler, $A$ Proposal to Rescind the Shareholder Proposal Rule, 18 GA. L. REV. 425, 454-57 (1984) (same). 
ordinarily better situated to make correct business decisions, but also that other shareholders will systematically overrate the benefits of alternative shareholder proposals. ${ }^{418}$

This analysis misses Arrow's fundamental insight that "[i]f every decision of $A$ is to be reviewed by $B$, then all we really have is a shift in the locus of authority from A to B." ${ }^{\prime 419}$ In addition, by assuming that a majority of shareholders need to act to influence corporate policies, Gordon fails to take into account the effect that less-thanabsolute delegation will undoubtedly have on informal channels of communication between shareholders and directors. Although, as Gordon notes, it seems unlikely that the majority of shareholders would systematically choose value-decreasing policies over the objections of management, ${ }^{420}$ granting shareholders collectively the power to vote on alternative policies greatly enhances the power of shareholders individually to apply pressure for change through informal channels. And regulating informal shareholder participation, like that in $\mathrm{Kmart}$, is much more difficult than regulating shareholder litigation or proxy solicitations because there is no practical method of preventing shareholders from informally contacting directors.

Even without a rule allowing broad shareholder participation in policy matters, institutional investors have begun to exercise significant influence through informal channels. In the Berle and Means corporation, informal participation was restricted by the board, which often chose not to listen or respond to shareholder concerns and suffered no adverse consequences from such a decision because no shareholder was large enough to retaliate. Institutional investors have increased the size of their share holdings, however, and they now command attention because of their potential to oust (or at least embarrass) directors in annual elections. The result is that the balance between authority and responsibility has shifted significantly towards responsibility in recent years.

\section{A Theory of Representation for Corporate Shareholders}

Arrow's analysis suggests that centralized decisionmaking adds value to corporations and identifies the balance of authority and responsibility as the key to maximizing that value; however, Arrow offers very little direction about how to strike the proper balance of authority and responsibility. Political theory, or more specifically, the

418. Gordon, supra note 30 , at 354.

419. ARROW, supra note 365 , at 78 .

420. Gordon, supra note 30, at 354-56. 
theory of representation, adds more texture to Arrow's insight, and teaches that the proper balance between authority and responsibility depends on the goal in designing a centralized decisionmaking mechanism. The following analysis proposes that directors serve the corporation best when they are allowed to use their independent judgment to represent the interests of shareholders and that, in such a system, the best check against managerial incompetence is meaningful director elections, not shareholder participation in deciding corporate policies.

Debates among political philosophers over the concept of representation have a long history, ${ }^{421}$ and most political theorists have concluded (like Arrow) that centralized decisionmaking-in this lexicon, "representation"-has value to a large organization. Giovanni Sartori suggests that representation has three distinct meanings: (1) the "juristic" meaning implies deputization by, or mandate from, the people being represented, so that the representative has no independent will but merely carries out the instructions of the people being represented, ${ }^{422}$ (2) the "sociological" meaning emanates from the fact of a resemblance or similarity that has nothing to do with voluntary selection or awareness; ${ }^{423}$ and (3) the "political" meaning suggests accountability or responsibility to the people being represented, but implies an independent will of the representative. ${ }^{424}$ It is impossible to determine in the abstract which form of representation is superior. ${ }^{425}$ That decision is inherently tied to the context of the representation.

421. For an excellent and oft-cited discussion of representation, with substantial historical information, see HANNA F. PITKIN, THE CONCEPT OF REPRESENTATION (1967).

422. Giovanni Sartori, Representational Systems, in 13 INTERNATIONAL ENCYCLOPEDIA OF THE SOCIAL SCIENCES 464, 465 (David L. Sills ed., 1968). For example, in the context of a law school, one might observe that "Jack and Jill are the student representatives conveying student demands for a tuition freeze to the Dean."

423. Id. at 465. Again in the law school context, one might contend that "Jack and Jill are representative of many students at the law school because they are interested in careers in environmental law."

424. Finally, in the law school context, one might note that "Jack and Jill are representing student interests in the debate over building expansion." Id. at 466 . Pitkin uses different words, but ends up with essentially the same concepts as Sartori. See PITKIN, supra note 421, passim; see also A.H. BIRCH, REPRESENTATION 15 (1971) (discussing the primary usages of the term "representative").

425. But cf. PITKIN, supra note 421 , at $144-67$ (attempting to mediate the mandateindependence controversy in the abstract, arguing that a representative who "habitually does the opposite of what his constituents would do" or who "does nothing" but carry out the orders of constituents is a representative "in name only"). 
The juristic meaning of representation sacrifices the benefits of centralized decisionmaking discussed above because the locus of authority no longer is with the representative but with the represented. In addition, in the context of the modern public corporation, representation by mandate is usually impractical or thought to be undesirable. Perhaps for this reason, shareholders have been restricted from giving instructions to directors through formal channels. As institutional investors become more active, however, incidents of juristic representation undoubtedly will proliferate through informal channels. Kmart is an example of such representation: institutional investors pressured Kmart's board to fire Antonini and the board complied. ${ }^{426}$

The sociological meaning of representation has gained increased attention in the corporate context recently, with calls to make directors more like shareholders by requiring minimum ownership interests in the corporation. Stock ownership is a deceptively simple answer to the principal/agent problem because although it provides directors with an incentive to maximize share price (with all of the attendant difficulties in doing so, as discussed above), it does not dictate the means to that end. With respect to means, different opinions inevitably exist. ${ }^{427}$ In the Kmart proxy contest, for example, opposition to the targeted stock proposal was voiced by shareholders with many different reasons for opposition. ${ }^{428}$ Although the opponents were able to agree on their opposition to the targeted stock proposal, they may not have agreed on a proper course of action afterwards. ${ }^{429}$

Although the director/shareholder relationship in modern public corporations may have some incidents of juristic or sociological representation, the dominant form of representation follows Sartori's political meaning. A key characteristic of this form of representation is the independence of the representative. ${ }^{430}$ Once it is admitted

426. Id. at 145 .

427. Bainbridge, supra note 345 , at 676 ("[M]ost shareholders presumably come to the corporation with profit-making as their principal goal. Their investment time horizons, however, are likely to vary from short-term speculation to long-term buy-and-hold strategies, which in turn is likely to result in disagreements about corporate strategy.").

428. See supra text accompanying note 88 .

429. Although all of the investors interviewed by John Pound at the request of Antonini wanted Kmart to sell the specialty retail subsidiaries, see supra text accompanying note 98 , these investors were not the only ones who opposed the targeted stock proposal.

430. Edmund Burke may be the person most closely identified with this view of representation. See EDMUND BURKE 20-21 (Isaac Kramnick ed., 1974). For a fuller account of Burke's concept of representation, see PITKIN, supra note 421, at 168-89; cf. 
that the representative may exercise independent judgment contrary to the will (though presumably not contrary to the interests) of the represented, it is possible to contend that the representative has lost the quality of "representation" and has become an "oligarch."431 This tension is what Hanna Pitkin calls the "central classic controversy in the literature of political representation." ${ }^{32}$ She frames the controversy as follows: "Should (must) a representative do what his constituents want, and be bound by mandates or instructions from them; or should (must) he be free to act as seems best to him in pursuit of their welfare?"433 Pitkin observes, however, that this statement of the controversy is actually misleading, because effective representation must have elements of both mandate and independence. ${ }^{434}$ In other words, the concept of representation implies that: (1) the representative must sometimes act independently or there is nothing more than the represented acting directly through an agent; ${ }^{45}$ and (2) the representative must act in the interests of the represented and thus normally not act in conflict with their wishes-otherwise the constituents cannot be said to be represented in any real sense. ${ }^{436}$

Of course, there is much room for play in a concept of representation that mixes elements of juristic representation with elements of political representation. There is no "right" answer in every situation to the issue of the proper mix, and the resolution depends on one's views "about what is represented; about the nature of interests, welfare or wishes; about the relative capacities of representative and constituents; and about the nature of the issues with which the representative must deal."437

BIRCH, supra note 424, at 37-49 (comparing Burke's views to others in England, America, and France).

431. PITKIN, supra note 421, at 150 (quoting Hillaire Belloc \& G.K. ChESTERTON, THE PARTY SYSTEM 17 (1911)).

432. Id. at 145 .

433. Id. "at 145. Sartori frames the debate as a choice between serving "the people" versus serving "the nation." See Sartori, supra note 422 , at 466.

434. PITKIN, supra note 421, at 166.

435. In such a case, the representative may be said to be "standing for" the represented, but not "acting for" them. PITKIN, supra note 421, at 153.

436. If the representative habitually acts contrary to the interests of the represented, there is at most formal representation. Id. Note that the congruence of interests and wishes requires the further assumption that what the represented wish for is actually in their interests. Id. at 156-62.

437. Id. at 210. 
In the context of corporate law, the mix between accountability to shareholders (mandate) and independence traditionally has been left ambiguous. Consider Easterbrook and Fischel:

Voting serves its principal role in permitting those who have gathered up equity claims to exercise control. Short of aggregating, however, some sort of collective informationgenerating agency is necessary. In a firm, the managers serve this function, and consequently it is unlikely that voters would think themselves able to decide with greater insight than the managers do. No wonder voters delegate extensively to managers and almost always endorse their decisions. But this acquiescence should not obscure the fact that managers exercise authority at the sufferance of investors. ${ }^{438}$

Whether the mix at any particular time leans too far in one direction or the other has seemed to depend more on personal predilection than systematic analysis. For example, Berle and Means argued that independence had overpowered accountability to the detriment of the shareholder. ${ }^{439}$ More recently, commentators have expressed concern that the pendulum may swing in the other direction..$^{40}$

Accepting the need for independent responsibility among corporate directors may lead to a situation in which the directors not only contravene the will of the shareholders, but act against their interests, ${ }^{441}$ either by design (moral hazard) or through incompetence (adverse selection). If market forces are ineffective constraints on moral hazard or adverse selection of directors (as may be inferred from the above discussion of the effect of market constraints on officers), shareholders must monitor directors to ensure that directors are acting in the interest of shareholders. When shareholders monitor directors, however, they run the risk of destroying the value of centralized decisionmaking. Thus the challenge in finding the right mix of accountability and independence

438. EASTERBROOK \& FISCHEL, supra note 90, at 67.

439. See BERLE \& MEANS, supra note 116 , at 122 .

If we are to assume that the desire for personal profit is the prime force motivating control, we must conclude that the interests of control are different from and often radically opposed to those of ownership; that the owners most Id. emphatically will not be served by a profit-seeking controlling group.

440. See Lipton \& Rosenblum, supra note 135 , at 188.

441. Sartori, supra note 422 , at 409. 
lies in gauging the relative costs of different types of shareholder monitoring.

As noted previously, shareholder monitoring of directors may involve essentially two forms of participation in the corporate governance process: board composition participation and policy participation. Corporate law currently provides formal mechanisms for both types of shareholder participation. Annual director elections determine board composition. Shareholder suits and shareholder initiatives usually involve policy participation. These formal mechanisms for shareholder participation are extremely ineffective at producing any real participation. Director elections are controlled by incumbent managers, and although it is theoretically possible for shareholders to participate in policy decisions through shareholder suits or shareholder proposals, as noted previously, corporate law has a decided bias against shareholder monitoring of policy matters through these formal mechanisms. ${ }^{42}$ Institutional investors who wish to influence the board of directors, therefore, typically resort (at least in the first instance) to pressure through informal channels.

John Pound praises shareholder participation through informal channels and contends that corporations should work more like government, where elections provide the mechanism for removing directors who do not respond to pressure through informal means. ${ }^{443}$ He calls this the political model of corporate governance and claims that this is the way "corporate statutes originally envisioned" things: "shareholders elect directors and directors monitor managers." 444 Pound claims that "[ $t]$ he most significant and defining aspect of the new political process is the rise of informal, political mechanisms to supplant, and even replace, the extreme measure of the formal voting challenge." ${ }^{445}$ These informal mechanisms are made possible by the increased concentration of share ownership in the hands of institutional investors. The result, according to Pound, is that corporate governance will begin to work much more like democratic politics in the public sector. ${ }^{446}$ The primary problem with Pound's analysis is that the medium of informal communication with the board of directors lends itself to policy participation rather than board

442. See supra notes $416-18$ and accompanying text.

443. Pound, supra note 191, at 1005-06, 1012.

444. Id. at 1006 .

445. Id. at 1008 .

446. Id. This view of corporate governance turns Ross Perot's 1992 presidential campaign promise to "run government like a business" on its head, suggesting that businesses should be run like a government! 
composition participation, a result that imposes significant costs on the decisionmaking process.

The primary difference in costs between board composition participation and policy participation is that shareholder monitoring of policy through informal channels forfeits the benefits of information cost economization that result from centralized decisionmaking. As observed by Stephen Bainbridge, "Large-scale institutional involvement in corporate decisionmaking seems likely to disrupt the very mechanism that makes the Berle-Means corporation practicable; namely, the centralization of decisionmaking authority in the board of directors." 447 The fact that institutional investors might act only in crisis situations does not reduce the costs of such action because if they are to override the board of directors, presumably the institutions must acquire as much information as the board.

The potential benefits of policy monitoring arise from the possibility that institutional investors would correct a mistaken business strategy or replace an incompetent CEO. But if board composition participation has been effective, there would be few differences of opinion between directors and shareholders and those that arise would be honest differences of opinion, in which directors believe they are pursuing the best interests of the shareholders, even when the shareholders disagree. This hearkens back to Pitkin's concept of representation, in which the representative must sometimes act independently but normally does not act in conflict with the wishes of the constituents. ${ }^{488}$ If directors are "representatives" of shareholders in this sense, there would be no reason to suspect that shareholders would systematically make better decisions regarding business strategy or replacing an incompetent CEO.

\section{Policy Implications}

The foregoing analysis suggests that the costs of allowing shareholders to monitor policy matters are great in comparison with the costs of allowing shareholders to monitor board composition, and that the marginal benefits of monitoring policy matters, if any, are small. These conclusions depend, however, on the ability of shareholders to elect directors who represent shareholder interests in the sense of representation described by Pitkin and Sartori. The policy implications follow naturally: Board composition participation

447. Bainbridge, supra note 345 , at 719-20.

448. See supra notes $433-36$ and accompanying text. 
should be encouraged to ensure representation and policy participation should be discouraged to avoid destruction of cost savings from centralized decisionmaking. The following sections propose two areas of concentration for future reform efforts: (1) because the primary mechanism for board composition participation in the current corporate governance system is annual director elections, such elections should be improved; and (2) because policy participation depends on a credible threat against directors from shareholders, boards should be insulated from that threat between elections by increasing the independence of directors and by lengthening the number of years between director elections.

\section{Encouraging Board Composition Participation}

The primary mechanism for board composition participation in the current corporate governance system is annual director elections. Sartori suggested that an effective counterweight to independence is free elections: "If he who is elected is not regarded as the representative of those who elect him, the election simply creates, per se, an absolute ruler.... Hence we need both election and representation." 449 Although corporate law provides for annual elections of directors, the elections typically do not offer a real choice. Elections of this type do not ensure effective representation, but merely provide the appearance of representation.

Director elections must be made more meaningful. There is no shortage of reform proposals on this issue, usually focusing on improving the nominating process. ${ }^{450}$ The foregoing analysis suggests that reform designed to enhance shareholder participation in director elections should be pursued. In addition to the many reforms already proposed, one aspect of this issue that has not been extensively addressed is the role of state shareholder voting rules.

State voting rules have been largely ignored by corporate law scholars since the passage of the Securities Exchange Act of 1934. 451 One prominent exception to this neglect is Frank Easterbrook and Daniel Fischel's claim that the structure of state shareholder voting

449. GIOVANNI SARTORI, THE THEORY OF DEMOCRACY REVISITED 29-30 (1987); see also Sartori, supra note 422 , at 467.

450. For a recent discussion, including a summary of proposals, see Carol Goforth, Proxy Reform as a Means of Increasing Shareholder Participation in Corporate Governance: Too Little, But Not Too Late, 43 AM. U. L. REv. 379, 448-53 (1994).

451. With respect to rules placing control over the corporate voting agenda in the hands of management, see Bratton \& McCahery, supra note 90, at 1873 (stating that "the law reform movement tends to press against only the federal side of a two-sided system"). 
laws-that is, "who votes, using what institutions-is contractual, and efficient too." "452 It is contractual in the sense that states typically allow firms great flexibility in choosing voting rules, and it is efficient in that such flexibility enables firms to adopt rules that promote the wealth of investors. Easterbrook and Fischel support this claimed efficiency by arguing that "[e]nduring practices are the best evidence of what constitutes the optimal allocation of resources on voting procedures."453 They add that the federal proxy rules, which displaced these "long-standing voluntary arrangements," are "not entitled to the same presumption of efficiency."454

Although Easterbrook and Fischel are selective in their discussion of state voting rules, their arguments relating generally to the efficiency of state voting rules are problematic in several respects. First, they assume that state voting rules are the result of a competitive market for corporate charters, which provides states with an incentive to adopt rules that will operate to the benefit of investors. But even Easterbrook and Fischel concede that the strong form of this argument-that "competition among states for incorporations always produces the optimal result" ${ }^{345}$ - has been refuted by the adoption of antitakeover statutes in most states, including Delaware. ${ }^{456}$ At best, one can argue now that "competition creates a powerful tendency for states to enact laws that operate to the benefit of investors. $\$ 457$

452. EASTERBROOK \& FISCHEL, supra note 90, at 63; see also Gordon, supra note 201, at 141-65 (discussing the history of cumulative voting).

453. Id at 81 .

454. Id. at 82.

455. Id. at 222.

456. $I d$.

457. Id. This is the familiar debate over whether the competition for corporate charters is a "race to the bottom" or a "race to the top." For the seminal works in this debate, see William L. Cary, Federalism and Corporate Law: Reflections Upon Delaware, 83 YALE L.J. 663 (1974); Ralph K. Winter, Jr., State Law, Shareholder Protection, and the Theory of the Corporation, $6 \mathrm{~J}$. LEGAL STUD. 251 (1977). For a recent defense of Delaware and state competition, see ROBERTA ROMANO, THE GENIUS OF AMERICAN CORPORATE LAW (1994). William Bratton has argued that no one (including Romano) currently defends the extreme positions in the debate, and that all scholars now seek some middle ground. See Bratton, supra note 131, at 401 . Several commentators have argued that the market for corporate charters is susceptible to supply-side inefficiencies. See Ian Ayres, Supply-Side Inefficiencies in Corporate Charter Competition: Lessons From Patents, Yachting and Bluebooks, 43 KAN. L. REv. 541 (1995); Lucian A. Bebchuk, Federalism and the Corporation: The Desirable Limits on State Competition in Corporate Law, 105 HARV. L. REV. 1437 (1992); Jonathan Macey \& Geoffrey Miller, Toward an Interest-Group Theory of Delaware Corporate Law, 65 TEX. L. REV. 469 (1987). 
Second, even if competition among states for corporate charters would produce the optimal voting rules over the long run, existing state voting rules should not necessarily be characterized as "longstanding." It is true that state voting rules have remained essentially unchanged for many years, but that probably is a function of the fact that the passage of the Securities Exchange Act of 1934 effectively halted change on the state level by shifting the forum for change to the federal level. Prior to the passage of the federal securities laws, state voting rules changed dramatically and often. Since the federal securities laws, there have still been important controversies and developments in shareholder voting, but they have centered on federal regulations. The fact that state voting rules have lain dormant for half a century should not be taken as evidence of their efficiency.

Finally, some existing state voting rules are demonstrably inefficient. One obvious candidate for this ignominious distinction is the procedure governing director elections. Directors are universally elected through plurality voting, but plurality voting is widely recognized as a "flawed system" for political elections. ${ }^{458}$ For example, in a recent study of nine election methods in British union elections, where voters ranked their preferences among several candidates, Jonathan Levin and Barry Nalebuff found that plurality voting frequently produced a different winner than the eight other methods, all of which obtained similar results. ${ }^{459}$

Unlike most political elections, elections of corporate directors typically are uncontested. Obviously, in an uncontested election the voting system is irrelevant. If corporate director elections were contested more often, the choice of voting system would assume increased importance, and alternatives to plurality voting, for example, approval voting ${ }^{460}$ or the single transferable vote, ${ }^{461}$ would probably increase the quality of representation (i.e., the resulting directors would better reflect the collective preferences of the shareholders). Although Easterbrook and Fischel did not defend as efficient the plurality voting system for the election of directors, it

458. See, e.g., Jonathan Levin \& Barry Nalebuff, An Introduction to Vote-Counting Schemes, J. ECON. PERSP., Winter 1995, at 3, 6-8.

459. Id. at 18. ("The other methods essentially differed only when there was a voting cycle, and even then, it did not affect the winner.").

460. Robert J. Weber, Approval Voting, J. ECON. PERSP., Winter 1995, at 39.

461. Nicolaus Tideman, The Single Transferable Vote, J. ECON. PERSP., Winter 1995, at 27 . 
serves as one obvious example that not all state voting rules are efficient. $^{462}$

The rule that toppled the targeted stock proposal requires the affirmative vote of a majority of the outstanding shares for approval of any charter amendment. Although all abstentions are effectively votes against a proposed amendment, shareholder apathy has not traditionally been an obstacle to approval of charter amendments proposed by management. The purpose of this rule appears to be to prevent management (which typically proposes charter amendments) from changing the terms of the "corporate contract" without the approval of a majority of the parties. Seen in this light, the rule makes sense. But as the size of institutional investor holdings increases, the traditional justification for the rule loses some of its force and the character of the rule changes. Instead of acting as an incentive to management to get out the vote, the rule skews the playing field in favor of opposition shareholders. Because a certain percentage of abstentions are inevitable, ${ }^{463}$ shareholders who oppose a proposed amendment may succeed in defeating it by convincing fewer than a majority of the outstanding shares (sometimes much fewer, as in Kmart) of the correctness of their position. Meanwhile, proponents of proposed charter amendments are forced to obtain the affirmative vote of a majority of outstanding shares in all events.

One might argue that this advantage for opponents cannot compensate for other obstacles, including the still popular "Wall Street Rule" (which states that investors who are dissatisfied with management can sell their shares and invest in another company that they find more hospitable) and management control over the proxy machinery. Nevertheless, if skewing the voting rules in favor of opposition shareholders is intended to compensate for other advantages of management, this is rough justice indeed. Moreover, the rule works against shareholder proposals in the same way that it works against management proposals. There appears to be no convincing efficiency justification for this voting rule.

If state shareholder voting rules are inefficient, why have they been so resistant to change over the past half century? One partial

462. It is presumed here that efficiency increases as shareholders choose directors who are more closely aligned with shareholder interests.

463. See, e.g., Roe, supra note 202, at 1937 tbl. I (showing high concentrations of share ownership in seven large German firms and the percentage of shares voted at the shareholder meetings averaging $58.33 \%$ ). As illustrated by Kmart, even when shares are highly concentrated in the hands of institutional investors, abstentions will occur for reasons unrelated to the collective action problem. 
explanation may be that offered above, namely, that the federal securities laws have now taken center stage, thus blunting evolution of state rules. Jonathan Levin and Barry Nalebuff propose another possible explanation: "Since those in power tend to want to preserve the status quo-the status quo electoral system is what brought them into power-we should not be surprised by the difficulty of implementing electoral reform." ${ }^{\text {464 }}$ Another possible explanation for stasis among state voting rules is that efficiency is not the predominant value that determines corporate voting rules. For example, simplicity in voting may be valued more highly than efficiency. ${ }^{465}$

In the context of $\mathrm{Kmart}$, it is unclear whether changes in state voting rules would have made any difference in the outcome of the dispute. When SWIB announced its opposition to the targeted stock proposal, it also encouraged other Kmart shareholders to vote against the five incumbent Kmart directors who were standing for reelection. ${ }^{466}$ Although many other shareholders publicly joined the fight against the targeted stock proposal, only some of those voted against the incumbent directors. ${ }^{467}$ The reasons for shareholders' reluctance to mount a direct challenge to Kmart's directors is difficult to determine. Perhaps because their frustration was directed primarily at Antonini and not the directors; perhaps because they knew it would be easier to defeat the targeted stock proposal than to gain support for insurgent directors; or perhaps because the current structure of legal rules, including state voting rules, "provides virtually no shareholder involvement in the nominating process, and, because of the manner in which directors are nominated, no meaningful role in voting." 468 Whatever the reason, consideration of these possibilities suggests that legal reform alone may not be sufficient to produce an immediate change in voting behaviors. ${ }^{469}$

464. Levin \& Nalebuff, supra note 458 , at $3-4$.

465. Id. at 19.

466. Duff, supra note 81 , at A2.

467. For example, the California Public Employees' Retirement System announced that it would vote against the incumbent directors but the New York City pension fund said it would not vote against the directors. Both investors opposed the targeted stock proposal. Kmart Stock Plan Opposed, supra note 83.

468. Goforth, supra note 450 , at 448.

469. Carol Goforth has noted:

Because the corporate governance model for American corporations has systematically excluded public shareholders from the directoral nominating process, there is no direct proof of how shareholders would respond if given the opportunity to nominate directors ... . [but] it seems safe to predict that at least some institutional investors will seek greater involvement in the directoral 


\section{Discouraging Policy Participation}

When Jeffrey Gordon constructed his arguments against policy participation by shareholders, he considered the potential of cumulative voting for encouraging shareholder monitoring of board composition. ${ }^{470}$ But devising a system in which shareholders participate in matters relating to board composition, and refrain from participating in policy matters, requires more than encouraging the former; the system must also discourage the latter. As noted above, access to formal mechanisms of policy participation (shareholder suits and shareholder proposals) is severely limited, but access to informal mechanisms of policy participation is largely unregulated. What makes those informal mechanisms effective, however, is the ultimate power of shareholders to elect directors. Ironically, then, the power that must be enhanced to realize gains in shareholder monitoring of board composition is the same power that must be subdued to reduce shareholder participation in policy matters. Despite the apparent paradox, the solution is straightforward: The power of shareholders to influence board composition is enhanced when director elections are real, and the power of shareholders to influence policy matters is diminished when director elections are less frequent.

Kmart serves as an illustration of how director elections might be used to engage in policy participation. The actions at issue in Kmart involved shareholder participation in matters of corporate strategy and CEO tenure. Replacing the CEO as chief strategist of the company requires only that someone other than the CEO formulate corporate stragegy. In the case of Kmart, institutional investors urged the implementation of their own strategy (concentration on discount retailing) even though the board of directors of Kmart had approved Antonini's strategy (combination discount and specialty retailing). This is a clear example of policy participation.

Replacing the CEO as chief administrator of the company, on the other hand, requires termination of the CEO. Although Gordon argued otherwise, ${ }^{471}$ for the sake of argument it will be assumed that

selection process if [allowed].

Id. at 451.

470. Gordon, supra note 201 , at $165-80$.

471. Gordon argued that the ouster of a CEO at the request of shareholders does not constitute "policy participation":

Where the company has unambiguously failed by appropriate performance measures, institutional pressure on the board to reshuffle the management team may be useful, not only for the particular firm's performance, but also as a 
when the institutional investors pressure'd Kmart's board of directors to terminate Antonini, the investors were engaged in policy participation. The institutional investors in $\mathrm{Kmart}$, therefore, engaged in policy participation with respect to corporate strategy and CEO tenure. Gordon argued that policy participation generally should be avoided and that board composition participation was preferred, but the institutional investors in Kmart could have achieved the same results through board composition participation if the existing directors had resisted pressure to change the corporate strategy and to terminate Antonini. In that circumstance, the institutional investors might have replaced the existing directors with other directors who were committed to the institutional investors' agenda. As illustrated by the foregoing example, shareholders can engage in policy participation either directly or through active board composition participation.

The most effective method of diminishing the power of shareholders over business policy is to take away their power to elect directors, but this would simultaneously remove an essential check on director behavior. Much the same result might be achieved, however, by extending the period between elections. Martin Lipton and Steven Rosenblum have proposed a radical overhaul of the corporate governance system, including replacement of annual elections with quinquennial elections. ${ }^{472}$ Strangely, the trend seems to be in the opposite direction. For example, Kmart's board of directors had staggered terms at the time of the targeted stock proposal, but

general deterrent. The institutions can be thought of as reminding the boards that their job is to monitor the performance of the managerial team on behalf of the shareholders. This is not inconsistent with what I have termed an "active" board composition strategy, since it focuses on bottom line performance and the board's monitoring role, and is backed by the implicit threat to try to change the board if it fails to respond. Far more problematic, in my view, would be pressure for adoption of particular business strategies, even by a company in crisis. This would amount to policy participation.

Id. at $141 \mathrm{n} .43$. Again, the events surrounding Antonini's ouster from Kmart provide insight. Obviously, shareholders pressured the board for Antonini's termination because of Kmart's poor performance generally; only a most unusual shareholder would agitate for change when a company is performing well. Nevertheless, the evidence surrounding Antonini's fall suggests that shareholders wanted the company to go in a new direction; they wanted a new business strategy and did not have confidence that Antonini could provide it. See supra notes 4-13 and accompanying text. It is hard to imagine a better way of changing company policy than replacing the chief policy maker of a company. Gordon's attempt to characterize the removal of the CEO as "board composition" participation, therefore, seems to ignore the substance of the action.

472. Lipton \& Rosenblum, supra note 135 , at 225-30. 
stockholders voted at the 1995 annual meeting to require annual elections of all directors. The purpose of such a change appears to be to make the board more accountable, but the effect may be to make them less "representative."

Extended terms between elections would have another benefit that has been overlooked in the voluminous literature on boards of directors, namely, to reduce the incidence of type II errors in making decisions regarding CEO tenure by deflecting shareholder pressure and criticism while the board performs its deliberative function.

An article of faith among observers of American corporations is that boards of directors are too slow to act in the face of subpar management performance. ${ }^{473}$ In the case of Kmart, this allegation was made by shareholders who claimed that the board was dragging its feet. ${ }^{474}$ Predictably, the day after Antonini resigned, the financial press reported that Professor Joseph Grundfest believed that "Kmart's board took too long in resolving its leadership situation." Monday morning quarterbacks were plentiful. ${ }^{476}$ The only people who seemed unconvinced were the directors themselves. Donald Perkins left no doubt that he did not want to ask Antonini to resign but was coerced by dissatisfied shareholders. ${ }^{47}$ And an article appearing in The New York Times days before Antonini's resignation reported that only four of eleven directors were "leaning against" Antonini ${ }^{478}$-this after months of pressure from shareholders to oust Antonini.

Skeptics may argue that this behavior is typical of American boards of directors, which are hopelessly biased in favor of incumbent management. But another interpretation seems equally plausible, at least in this case: the board may have been giving Antonini time to execute a strategy on which Antonini and the board agreed. ${ }^{479}$ For

473. See, e.g., Lipton \& Lorsch, supra note 227 , at 59 (noting that General Motors board of directors acted too late in ousting CEO).

474. See, e.g., Duff \& Lublin, supra note 5, at A3 (quoting SWIB's James Severance as saying "[t]he board was too passive").

475. Duff et al., supra note 12 , at A10.

476. See, e.g., Angela G. King, Kmart faces Shareholders' Tough Test, USA TODAY, May 22, 1995, at 5B (stating that "[m]any investors . . . say the board let Antonini run KMart far too long").

477. Ellen Neuborne, Kmart Chief Antonini Calls It Quits, USA TODAY, Mar. 22, 1995, at $1 \mathrm{~B}$ (quoting Perkins describing his disappointment at having to ask Antonini to resign).

478. Dobrzynski \& Strom, supra note 11, at D6.

479. Neuborne, supra note 477, at 1B (quoting Perkins as saying, "I started out in January ... [thinking] we could buy time for Joe to fix the problems that needed to be fixed"). 
purposes of corporate governance, the question is straightforward: Who should decide whether a manager is competent to run the corporation? As discussed in the previous section, placing that policy decision in the hands of shareholders would not increase-and may decrease-the value of the corporation. But some may be concerned about placing too much power in the hands of the directors. This is especially a concern if shareholders have no practical exit option. Enter the independent directors.

Assuming that the decision regarding managerial incompetence is best left to the board of directors as the well-informed central decisionmaker, independent directors may perform the valuable function of lending credibility to a decision not to fire the CEO. If shareholders are able to trust the process, they will be less likely to interfere and impose the costs of shareholder action discussed above. If a board composed of inside directors defers action when a company passes into troubled times, outsiders are quick to accuse the board of unduly favoring management. But credible outside directors may instill confidence in the decisionmaking process, thus reducing type II errors without increasing type I errors.

\section{CONCLUSION}

Over two months after Antonini's ouster, Kmart hired Floyd Hall, the former head of Target, as Chairman, CEO, and President of Kmart. ${ }^{480}$ The first months of Hall's reign have been tumultuous, and with less than one year on the job, he has already been the subject of two very negative stories in major business magazines, both arguing that he does not have the vision to reverse Kmart's sagging performance. ${ }^{481}$ In addition, a recent survey by Fortune magazine suggests that Kmart's reputation among its competitors has fallen even further than when Antonini was in charge. ${ }^{482}$ Kmart's stock price reflects Hall's troubles. When Antonini was forced to resign as CEO and President of Kmart on March 21, 1995, Kmart's common stock was trading for twelve dollars per share; during the first months of 1996, Kmart's stock has hovered below ten dollars per share.

480. Duff \& Lublin, supra note 240 , at A3.

481. See Patricia Sellers, Kmart Is Down for the Count . . a and Floyd Hall Doesn't Look Like the Man to Get It Back on Its Feet, ForTUNE, Jan. 15, 1996, at 102; Bill Vlasic \& Keith Naughton, Kmart: Who's In Charge Here? CEO Hall Is as Elusive as the Retailer's Recovery, Bus. WK., Dec. 4, 1995, at 104.

482. Anne B. Fisher, Corporate Reputations: Comebacks and Comeuppances, FORTUNE, Mar. 6, 1996 (rating Kmart 415 out of 417 companies by executives, outside directors, and financial analysts). 
Shortly after Hall assumed control, bankruptcy rumors surfaced ${ }^{483}$ and in November 1995 the rumors started to take on new seriousness when it was revealed that Kmart had \$681 million of secured, real estate-related bonds with unusual put provisions requiring Kmart to repay the entire outstanding amount of the bonds on demand if its credit rating fell below investment grade. ${ }^{484}$ In December Kmart came to an agreement in principle with the holders of the bonds under which Kmart would eliminate its remaining dividend while the bondholders would agree to remove the troubling put provision. ${ }^{485}$ Within weeks both Standard \& Poor's and Moody's lowered their ratings on some of Kmart's outstanding debt securities to junk-bond status. ${ }^{486}$

If Kmart suffers from a lack of leadership, as the business press claims, then the company was dealt another blow at the close of 1995 when Donald Perkins resigned as a director. Having acted as Chairman of Kmart during the final months of Antonini's tenure, Perkins was the only Kmart outside director with retail experience. ${ }^{477}$ Kmart's institutional investors, who were instrumental in Antonini's ouster, have been publicly silent during Hall's initiation. If Kmart's current poor performance continues, however, the question raised at the beginning of this Article undoubtedly will be raised again: When institutional investors are dissatisfied with the performance of a company in which they have invested, how much power should the corporate governance system grant those investors to pursue their own remedy, rather than relying on market checks or the board of directors?

483. Linda Sandler, Kmart Should Consider a Chapter 11 Filing as Best Vehicle for Drastic Changes, Some Say, WALL ST. J., Oct. 16, 1995, at C2.

484. Linda Sandler, Kmart Is Pressured Over Obscure Bond 'Puts,' Which Stir Worries Amid Tough Retail Times, WALl ST. J., Nov. 6, 1995, at C2.

485. Robert Berner, Kmart Ends Payout, Sets Bond Accord, WALl ST. J., Dec. 21, 1995, at A3. Kmart finally concluded the agreement in March, 1996. Robert Berner, Kmart Gains Reprieve in Final Accord, But Retailer to Post Loss for Quarter, WALL ST. J., Mar. 4, 1996, at B4. Also in December 1995, Kmart filed a $\$ 1.2$ shelf registration statement with the SEC and later announced that it was considering a public offering to pay off some of its troublesome short-term debt. Laura Jereski \& Robert Berner, Kmart Weighs Securities Issue of $\$ 750$ Million, WALL ST. J., Feb. 1, 1996, at A4.

486. Robert Berner, $S \& P$ Cuts Kmart to Junk Status, But Discounter Says It's on Track, WALl ST. J., Jan. 15, 1996, at B4; Robert Berner, Some Kmart Debt Gets Junk-Bond Mark, But Moody's Hints at Better Days Ahead, WALL ST. J., Feb. 5, 1996, at B4.

487. Kmart Ex-Chairman Perkins Quits Post on Retailer's Board, WALL ST. J., Feb. 12, 1996, at B8. Perkins and another director, F. James McDonald, who also retired at the end of 1995, were replaced by two new directors, both of whom are CEOs for nonretailing companies. Who's News: Kmart Corp., WALL ST. J., Mar. 7, 1996, at B2. 
As can be observed from events surrounding Antonini's ouster, when investors are concerned about managerial incompetence (as opposed to managerial abuse), they cannot rely on market forces to protect them. The board of directors may not provide much assistance, either, depending on its composition. In that circumstance, shareholders possess as much power as they can exert through informal channels, reinforced by the threat of formal action through director elections or, in the extreme case, shareholder suits.

As for the normative question-how much power should shareholders possess-the analysis in this Article suggests that the best allocation of power vests control over policy decisions in directors, with shareholders exercising the power to choose the directors who represent them. Although corporate statutes already are designed to function in this manner, practice suggests that shareholders typically do not wield much power in the selection of directors but may be gaining power in policy matters through informal participation. This Article proposes, therefore, that the focus of corporate governance reform efforts center on rules governing director elections. In addition, proposed reforms must incorporate means of discouraging attempts by shareholders to exercise power through informal channels. 
$+$ 